\title{
6-(Ar)Alkylamino-Substituted Uracil Derivatives: Lipid Mimetics with Potent Activity at the Orphan G Protein-Coupled Receptor 84 (GPR84)
}

Thanigaimalai Pillaiyar, ${ }^{\dagger}$ (๑ Meryem Köse, ${ }^{\dagger}$ Vigneshwaran Namasivayam, ${ }^{\dagger}$ Katharina Sylvester, Gleice Borges, ${ }^{\dagger}$ Dominik Thimm, ${ }^{\dagger}$ Ivar von Kügelgen, ${ }^{\dagger}$ and Christa E. Müller* ${ }^{\dagger}+0$

${ }^{\dagger}$ PharmaCenter Bonn, Pharmaceutical Institute, Pharmaceutical Chemistry I, University of Bonn, An der Immenburg 4, D-53121 Bonn, Germany

${ }^{\ddagger}$ Department of Pharmacology and Toxicology, University of Bonn, 53105 Bonn, Germany

Supporting Information

ABSTRACT: GPR84, a $G_{i}$ protein-coupled receptor that is activated by medium-chain (hydroxy)fatty acids, appears to play an important role in inflammation, immunity, and cancer. Recently, 6-octylaminouracil (4) has been reported to act as an agonist at GPR84. Here, we describe the synthesis of 69 derivatives and analogs of 4, 66 of which represent new compounds. They were evaluated in (a) cyclic adenosine monophosphate accumulation and (b) $\beta$-arrestin assays in human GPR84-expressing cells. Potent nonbiased as well as G protein-biased agonists were developed, e.g., 6-hexylamino2,4(1H,3H)-pyrimidinedione (20, PSB-1584, $\mathrm{EC}_{50} 5.0 \mathrm{nM}(\mathrm{a})$, $3.2 \mathrm{nM}$ (b), bias factor: 0$)$ and 6-( (p-chloro- and p-bromophenylethyl)amino)-2,4(1H,3H)-pyrimidinedione (47, PSB16434, $\mathrm{EC}_{50} 7.1 \mathrm{nM}(\mathrm{a}), 520 \mathrm{nM}$ (b), bias factor: 1.9 = 79-fold $\mathrm{G}_{\mathrm{i}}$ pathway-selective; 48, PSB-17365, EC $502.5 \mathrm{nM}$ (a), 100 $\mathrm{nM}(\mathrm{b})$, bias factor $1.3=20$-fold selective), which were selective versus other free fatty acid-activated receptors. Compounds 20 and 48 were found to be metabolically stable upon incubation with human liver microsomes. A pharmacophore model was created on the basis of structurally diverse lipidlike GPR84 agonists.

\section{INTRODUCTION}

G protein-coupled receptors (GPCRs) are seven transmembrane receptors that constitute one of the largest gene families in the human genome. ${ }^{1,2}$ They are considered attractive targets for the development of drugs for many human diseases, and it has been estimated that about $30 \%$ of modern drugs target GPCRs, including many of the world's best-selling pharmaceuticals. ${ }^{3,4}$ More than 100 GPCRs represent orphan receptors, whose natural ligands are still unknown or unconfirmed. ${ }^{5}$ GPR84 is a so far poorly investigated GPCR that is activated by micromolar concentrations of medium-chain fatty acids with carbon chain lengths of 9-14, which couples to the $G_{i / o}$ pathway. ${ }^{6-8}$ The receptor is predominantly expressed in immune system-related tissues and cells, such as bone marrow, spleen, lung, lymph nodes, ${ }^{9}$ and brain microglia. Moreover, it is expressed in adipose tissue. ${ }^{10,11}$ GPR84 expression is upregulated in macrophages upon lipopolysaccharide (LPS) stimulation, where it regulates the production of interleukin-12 (IL-12), a proinflammatory cytokine that controls the balance of $\mathrm{T}$ helper (Th1/Th2) responses and plays an important role in inflammatory diseases such as rheumatoid arthritis and inflammatory bowel disease. ${ }^{12}$ The potential role of GPR84 in this context has been supported by the finding that knockout of GPR84 in T cells leads to

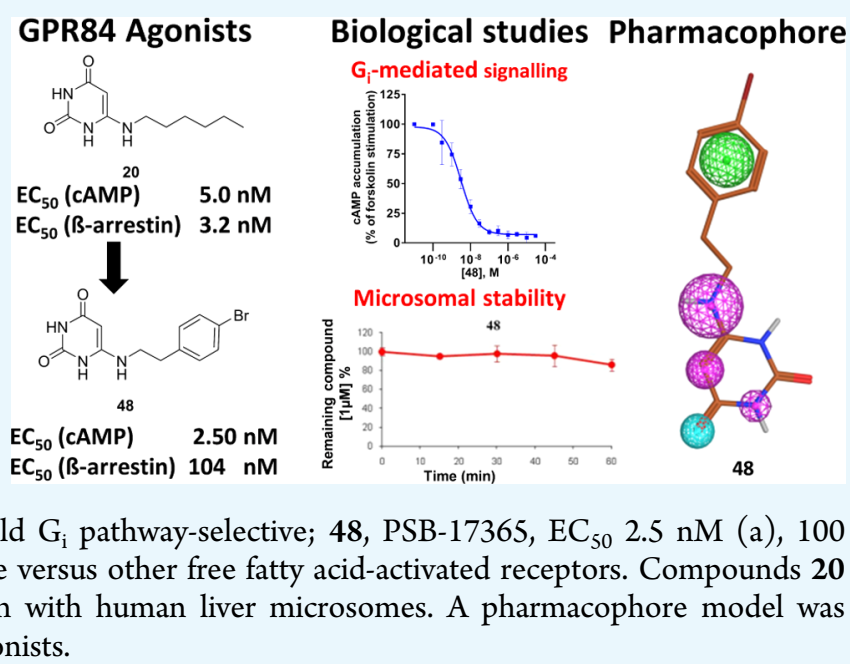

GPR84 Agonists

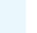
\section{(1)}


<smiles>CCCCCCCCCC(=O)O</smiles>

1 Decanoic acid<smiles>CCCCCCCCCCC[C@H](O)CC(=O)O</smiles>

3 3-Hydroxytetradecanoic acid<smiles>CCCCCCSc1nc(O)cc(O)n1</smiles>

5 2-Hexylthiopyrimidine-4,6-diol<smiles>c1ccc2c(Cc3c[nH]c4ccccc34)c[nH]c2c1</smiles>

7 3,3'-Diindolylmethane (DIM)<smiles>CCCCCCCCC[C@H](O)CC(=O)O</smiles>

2 3-Hydroxydodecanoic acid

Head

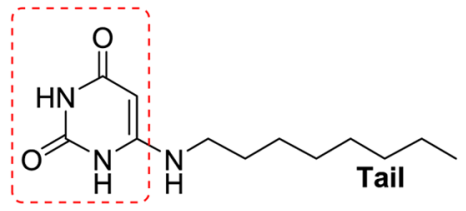

4 6-Octylaminouracil<smiles>CCCCCCCCCCCC1=C(O)C(=O)C=C(O)C1=O</smiles>

6 Embelin<smiles>Fc1cc(F)c2[nH]cc(Cc3c[nH]c4c(F)cc(F)cc34)c2c1</smiles>

8 3,3'-Di-(5,7-difluoro-1 $H$-indol-3yl)methane (PSB-16671)

Figure 1. Structures of reported GPR84 agonists.

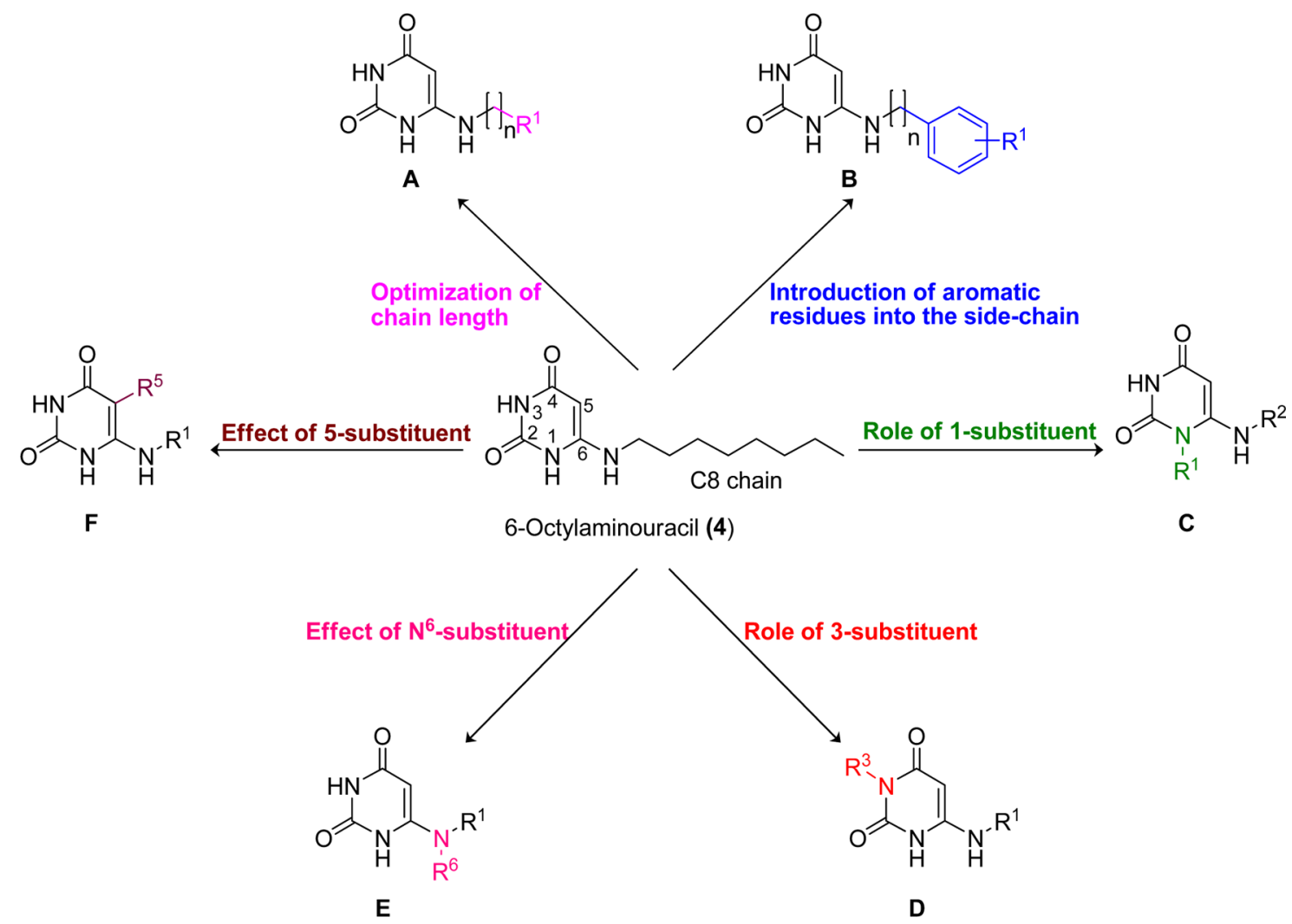

Figure 2. Structural modifications of lead compound 4. 
Scheme 1. Synthesis of 5-Alkylamino or 6-(Ar)Alkylamino-Substituted Uracil Derivatives (4 and 14-80 $)^{a}$<smiles>[R]n1c(Cl)cc(=O)n([R1])c1=O</smiles><smiles>Clc1cc(Cl)nc(Cl)n1</smiles><smiles></smiles>
12a; $\mathrm{R}^{1}=\mathrm{H}, \mathrm{R}^{2}=\mathrm{CH}_{3}$ 12b; $\mathrm{R}^{1}=\mathrm{CH}_{3}, \mathrm{R}^{2}=\mathrm{H}$ 12c; $\mathrm{R}^{1}=\mathrm{R}^{2}=\mathrm{CH}_{3}$<smiles>[R]Nc1c([R4])c(=O)n([R])c(=O)n1[R]</smiles>

4, 14-38, 40-71

For $\mathrm{R}^{1}-\mathrm{R}^{4}$

72-75 or $\mathbf{7 6 - 8 0}$

see Tables 1-3<smiles>O=c1[nH]cc(Br)c(=O)[nH]1</smiles>

13

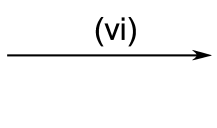

${ }^{a}$ Reagents and condition: (i) $\mathrm{POCl}_{3}$, dimethylaniline, $50{ }^{\circ} \mathrm{C}, 7 \mathrm{~h}$ and $125{ }^{\circ} \mathrm{C}, 20 \mathrm{~min}$; (ii) aqueous $\mathrm{NaOH}$, reflux, $3 \mathrm{~h}$; (iii) $\mathrm{K}_{2} \mathrm{CO}_{3}, \mathrm{CH}_{3} \mathrm{I}$, dimethyl sulfoxide (DMSO), room temperature (rt), $2 \mathrm{~h}$ or $\mathrm{K}_{2} \mathrm{CO}_{3}, N, N^{\prime}$-dimethylformamide (DMF), $6 \mathrm{~h}$ for 12a and $12 \mathrm{~b}$ or $\mathrm{K}_{2} \mathrm{CO}_{3}, \mathrm{CH}_{3} \mathrm{I}, \mathrm{DMF}, 50{ }^{\circ} \mathrm{C}, 12$ $\mathrm{h}$ for 12c; (iv) amines, 1-butanol, reflux, $12 \mathrm{~h}$; (v) pyridine, $\mathrm{N}$-bromosuccinimide (NBS), $80{ }^{\circ} \mathrm{C}, 2 \mathrm{~h}$ for $72-75$ from 20, 6, 47, and 43; or $\mathrm{NaNO}_{2}$, $\mathrm{CH}_{3} \mathrm{COOH} / \mathrm{H}_{2} \mathrm{O}(1: 1), 60-70{ }^{\circ} \mathrm{C}, 1 \mathrm{~h}$ and cooled to $4{ }^{\circ} \mathrm{C}$ for $76-80$ from 6, 20, 21, 42, and 43, 67-79\%; (vi) hexylamine, 1-butanol, reflux, $12 \mathrm{~h}$.

of GPR84 by agonists might lead to a functional blockade of the receptor, resulting in anti-inflammatory effects and possibly antiproliferative effects on acute myeloid leukemia. ${ }^{15}$

In 2006, GPR84 was shown to be activated by medium-chain free fatty acids with chain lengths of C9-14. In particular, decanoic acid (C10, 1, Figure 1), undecanoic acid (C11) and lauric acid (C12) were found to be among the most potent agonists of GPR84. ${ }^{7}$ Other studies by Suzuki et al. reported 2- or 3-hydroxy fatty acids to be comparatively more potent than the nonhydroxylated fatty acids, ${ }^{8}$ and recently, Hoffmann et al. have found that 3-hydroxytetradecanoic acid effectively activates GPR84 (compounds 2 and 3, see Figure 1). ${ }^{16}$ Moreover, 6octylaminouracil (4, Figure 1$)^{8}$ and the structurally related (hexylthio)pyrimidine-4,6-diol (5, Figure 1) and its derivatives were identified as synthetic GPR84 agonists. ${ }^{17,18}$ Compound 4, which displays a lipid-mimetic structure, was reported to activate human GPR84 with an $\mathrm{EC}_{50}$ value of $512 \mathrm{nM}$ determined in $\left[{ }^{35} \mathrm{~S}\right] \mathrm{GTP} \gamma \mathrm{S}$ binding assays. ${ }^{8}$ Compound 5 exhibited GPR84 agonistic activity with an $\mathrm{EC}_{50}$ of $139 \mathrm{nM}$ determined in a calcium mobilization assay in HEK293 cells recombinantly expressing the human GPR84. ${ }^{17,18}$

Embelin (6, Figure 1), a natural product isolated from the plant Embelia ribes (Myrsinaceae), also activates GPR84 (EC ${ }_{50}$ $795 \mathrm{nM}$, cyclic adenosine monophosphate (cAMP) assay, see Table 1) ${ }^{19}$ Embelin was reported to have anticancer, antioxidant, anthelmintic, antifertility, antitumor, antiapoptotic, antimicrobial, analgesic, and anti-inflammatory activities. ${ }^{20-22}$ The safety and toxicity profile of embelin in rodents and nonrodents was investigated and the compound was found to be safe up to $3 \mathrm{~g} / \mathrm{kg}$ (orally) when tested in rodents after acute exposure. Embelin was reported to act as an X-linked inhibitor of apoptosis $\left(\mathrm{IC}_{50} 4.1\right.$ $\mu \mathrm{M})$ besides interaction with other targets, ${ }^{23}$ but it is even more potent as an agonist of GPR84. Diindolylmethane (DIM, 7), ${ }^{8,24}$ another natural product-derived compound that activates GPR84, also possesses anticancer activity. ${ }^{25}$ In a previous study, we investigated the structure-activity relationships (SARs) of DIM derivatives and analogues and developed a potent and selective GPR84 agonist derived from DIM, compound 8 (PSB-16671), with an $\mathrm{EC}_{50}$ value of $41.3 \mathrm{nM}$ (Figure 1). ${ }^{26}$ DIM derivatives were characterized as agonists with an ago-allosteric mechanism of action as compared to fatty acids. $^{26,27}$ In the present study, we used the potent and selective GPR84 agonist $\mathbf{4}$ as a lead structure. Our goal was to study the SARs of 6-aminouracil derivatives and analogues as GPR84 agonists, to improve their potency, optimize their properties, including selectivity and metabolic stability, and develop $G_{i}$ protein-biased agonists.

\section{RESULTS AND DISCUSSION}

Compound Design. To get insights into the SARs of uracil derivatives as GPR84 agonists, the following structural modifications of the lead agonist 4 were made (Figure 2): (A) optimization of the alkyl chain length; (B) introduction of aromatic residues into the side chain, probing the importance of the hydrogen bond donors: (C) N1-H, (D) N3-H, and (E) $\mathrm{N}^{6}-\mathrm{H}$; and $(\mathrm{F})$ introduction of a substituent at position 5 of the uracil moiety. 
Table 1. Agonistic Activity of 6-Alkylaminouracils and Standard Agonists at GPR84 ${ }^{a}$

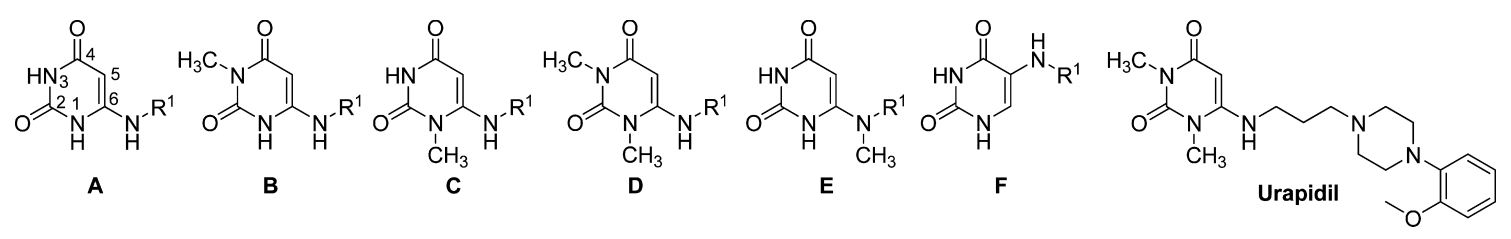

\begin{tabular}{|c|c|c|c|c|}
\hline \multirow[b]{3}{*}{ compound } & \multirow[b]{3}{*}{$\mathrm{R}^{1}$} & \multicolumn{2}{|c|}{ human GPR84 } & \multirow[b]{3}{*}{$\begin{array}{c}\text { bias factor } \\
\Delta \Delta \log \left(E_{\max } / \mathrm{EC}_{50}\right)\end{array}$} \\
\hline & & cAMP assay $^{b}$ & $\beta$-arrestin assay & \\
\hline & & $\begin{array}{c}\mathrm{EC}_{50} \pm \mathrm{SEM}(\mu \mathrm{M}) \text { (or percent receptor } \\
\text { activation at } 10 \mu \mathrm{M})^{b}[\text { efficacy }]^{t}\end{array}$ & $\begin{array}{c}\mathrm{EC}_{50} \pm \mathrm{SEM}(\mu \mathrm{M}) \text { (or percent receptor } \\
\text { activation at } 10 \mu \mathrm{M})[\text { efficacy }]^{d}\end{array}$ & \\
\hline \multicolumn{5}{|c|}{ Standard Agonists (For Structures, See Figure 1) } \\
\hline \multicolumn{2}{|l|}{ decanoic acid (1) } & $7.4 \pm 0.4[100 \%]$ & $6.1 \pm 0.4[92 \%]$ & 0.0 \\
\hline \multicolumn{2}{|c|}{$(R, S)$-3-hydroxydodecanoic acid (2) } & $1.3 \pm 0.15[92 \%]$ & $4.4 \pm 1.30[90 \%]$ & 0.0 \\
\hline \multicolumn{2}{|l|}{ embelin (6) } & $0.80 \pm 0.17[86 \%]$ & $0.42 \pm 0.19[100 \%]$ & -0.3 \\
\hline \multicolumn{2}{|c|}{ urapidil (for structure see above) } & $>10(7 \%)$ & n.d. ${ }^{f}$ & n.d. \\
\hline \multicolumn{2}{|c|}{ 2-hexylthiopyrimidine-4,6-diol $(5)^{g}$} & $\mathbf{0 . 0 0 6 6} \pm 0.0041[153 \%]$ & $\mathbf{0 . 0 7 8} \pm 0.049[242 \%]$ & 0.9 \\
\hline \multicolumn{5}{|c|}{ Structure A: 6-Alkylaminouracils } \\
\hline \multicolumn{2}{|r|}{$-\mathrm{CH}_{2}\left(\mathrm{CH}_{2}\right)_{6}-\mathrm{CH}_{3}$} & $\mathbf{0 . 0 1 7} \pm 0.003[104 \%]$ & $0.11 \pm 0.04[189 \%]$ & 0.6 \\
\hline \multicolumn{2}{|r|}{$-\mathrm{CH}_{2} \mathrm{CH}_{3}$} & $>\mathbf{1 0}(15 \%)$ & n.d. & n.d. \\
\hline \multicolumn{2}{|r|}{$-\mathrm{CH}_{2} \mathrm{CH}_{2} \mathrm{CH}_{3}$} & $\gg 10(-9 \%)$ & n.d. & n.d. \\
\hline \multicolumn{2}{|r|}{$-\mathrm{CH}_{2} \mathrm{CH}\left(\mathrm{CH}_{3}\right)_{2}$} & $>\mathbf{1 0}(11 \%)$ & n.d. & n.d. \\
\hline \multicolumn{2}{|r|}{$-\mathrm{CH}_{2} \mathrm{C}\left(\mathrm{CH}_{3}\right)_{3}$} & $>10(4 \%)$ & n.d. & n.d. \\
\hline 17 & $-\mathrm{CH}_{2} \mathrm{CH}_{2} \mathrm{CH}\left(\mathrm{CH}_{3}\right)_{2}$ & $>10(14 \%)$ & n.d. & n.d. \\
\hline 18 & $-\mathrm{CH}_{2} \mathrm{CH}_{2} \mathrm{C}\left(\mathrm{CH}_{3}\right)_{3}$ & $>10(18 \%)$ & n.d. & n.d. \\
\hline 19 & $-\mathrm{CH}_{2}\left(\mathrm{CH}_{2}\right)_{3}-\mathrm{CH}_{3}$ & $\mathbf{0 . 4 6} \pm 0.13[106 \%]$ & $4.8 \pm 1.3[147 \%]$ & 0.9 \\
\hline 20 (PSB-1584) & $-\mathrm{CH}_{2}\left(\mathrm{CH}_{2}\right)_{4}-\mathrm{CH}_{3}$ & $0.0050 \pm 0.0013[127 \%]$ & $\mathbf{0 . 0 0 3 2} \pm 0.0011[98 \%]$ & 0.0 \\
\hline 21 & $-\mathrm{CH}_{2}\left(\mathrm{CH}_{2}\right)_{5}-\mathrm{CH}_{3}$ & $0.012 \pm 0.006[113 \%]$ & $\mathbf{0 . 3 9} \pm 0.07[250 \%]$ & 1.2 \\
\hline 22 & $-\mathrm{CH}_{2}\left(\mathrm{CH}_{2}\right)_{7}-\mathrm{CH}_{3}$ & $\mathbf{0 . 0 3 0} \pm 0.010[118 \%]$ & $\mathbf{0 . 0 3 4} \pm 0.007[142 \%]$ & 0.0 \\
\hline 23 & $-\mathrm{CH}_{2}\left(\mathrm{CH}_{2}\right)_{8}-\mathrm{CH}_{3}$ & $\mathbf{0 . 0 2 1} \pm 0.002[109 \%]$ & $\mathbf{0 . 3 6} \pm 0.01[109 \%]$ & 1.3 \\
\hline 24 & $\begin{array}{l}-\mathrm{CH}_{2} \mathrm{CH}\left(\mathrm{CH}_{2} \mathrm{CH}_{3}\right)- \\
\left(\mathrm{CH}_{2}\right)_{3} \mathrm{CH}_{3}\end{array}$ & $>10(14 \%)$ & n.d. & n.d. \\
\hline 25 & $\begin{array}{l}-\mathrm{CH}_{2}\left(\mathrm{CH}_{2}\right)_{4}- \\
\mathrm{CH}\left(\mathrm{CH}_{3}\right)_{2}\end{array}$ & $5.9 \pm 2.6[99 \%]$ & n.d. & n.d. \\
\hline 26 & $\begin{array}{l}-\mathrm{CH}_{2}-\left(\mathrm{CH}_{2}\right)_{2}-\mathrm{S}- \\
\mathrm{CH}_{3}\end{array}$ & $23 \pm 3[100 \%]$ & n.d. & n.d. \\
\hline 27 & $-\mathrm{CH}_{2}\left(\mathrm{CH}_{2}\right)_{5}-\mathrm{OH}$ & $\geq 10(51 \pm 8 \%)$ & n.d. & n.d. \\
\hline 28 & $-\mathrm{CH}_{2}\left(\mathrm{CH}_{2}\right)_{6}-\mathrm{OH}$ & $2.0 \pm 0.5[105 \%]$ & $2.1 \pm 0.6[211 \%]$ & -0.2 \\
\hline 29 & $-\mathrm{CH}_{2}\left(\mathrm{CH}_{2}\right)_{4}-\mathrm{COOH}$ & $>10(25 \%)$ & n.d. & n.d. \\
\hline 30 & $-\mathrm{CH}_{2}\left(\mathrm{CH}_{2}\right)_{6}-\mathrm{COOH}$ & $>10(13 \%)$ & n.d. & n.d. \\
\hline Structure B: 3-N & ethyl-Substituted Uracil & ivatives & & \\
\hline 31 & $-\mathrm{CH}_{2}\left(\mathrm{CH}_{2}\right)_{6}-\mathrm{CH}_{3}$ & $\mathbf{0 . 7 2} \pm 0.27[95 \%]$ & $>10(32 \%)$ & $>1.2$ \\
\hline 32 & $-\mathrm{CH}_{2}\left(\mathrm{CH}_{2}\right)_{7}-\mathrm{CH}_{3}$ & $2.0 \pm 0.5[74 \%]$ & n.d. & n.d. \\
\hline 33 & $-\mathrm{CH}_{2}\left(\mathrm{CH}_{2}\right)_{8}-\mathrm{CH}_{3}$ & $1.9 \pm 0.68[72 \%]$ & $>10(8 \%)$ & $>0.6$ \\
\hline Structure C: $1-1$ & lethyl-Substituted Uracil & ivatives & & \\
\hline 34 & $-\mathrm{CH}_{2}\left(\mathrm{CH}_{2}\right)_{4}-\mathrm{CH}_{3}$ & $>10(32 \%)$ & n.d. & n.d. \\
\hline 35 & $-\mathrm{CH}_{2}\left(\mathrm{CH}_{2}\right)_{6}-\mathrm{CH}_{3}$ & $>10(34 \%)$ & n.d. & n.d. \\
\hline Structure D: 1,3 & Dimethyl-Substituted U & Derivative & & \\
\hline 36 & $-\mathrm{CH}_{2}\left(\mathrm{CH}_{2}\right)_{6}-\mathrm{CH}_{3}$ & $>10(25 \%)$ & n.d. & n.d. \\
\hline Structure E: $\mathrm{N}^{6}$ & Methyl-Substituted Uraci & rivatives & & \\
\hline 37 & $-\mathrm{CH}_{2}\left(\mathrm{CH}_{2}\right)_{4}-\mathrm{CH}_{3}$ & $0.11 \pm 0.04[106 \%]$ & $4.2 \pm 0.7[278 \%]$ & 1.2 \\
\hline 38 & $-\mathrm{CH}_{2}\left(\mathrm{CH}_{2}\right)_{6}-\mathrm{CH}_{3}$ & $\mathbf{0 . 0 3 8} \pm 0.020[107 \%]$ & $0.64 \pm 0.02[309 \%]$ & 0.8 \\
\hline Structure F: 5-A & kylamino-Substituted Ur & Derivative & & \\
\hline 39 & $-\mathrm{CH}_{2}\left(\mathrm{CH}_{2}\right)_{6}-\mathrm{CH}_{3}$ & $>10(6 \%)$ & n.d. & n.d. \\
\hline
\end{tabular}

${ }^{a} \mathrm{EC}_{50}$ values are shown in bold. Efficacy is in italic. ${ }^{b}$ Inhibition of forskolin $(10 \mu \mathrm{M})$-induced decrease in cAMP accumulation. ${ }^{c}$ Efficacy $\left(E_{\max }\right)$ relative to the max. effect of decanoic acid $(100 \mu \mathrm{M})(=100 \%) .{ }^{d}$ Efficacy $\left(E_{\max }\right)$ relative to the max. effect of embelin $(10 \mu \mathrm{M})(=100 \%) .{ }^{e}$ Bias factor was calculated as described in Experimental Section. $f_{\text {n.d., not determined. }}{ }^{\mathrm{A}}$ literature value of $0.144 \mu \mathrm{M}$ was reported for this compound, determined in a homogeneous time-resolved fluorescence assay (Cisbio) on HEK293 cells stably expressing human GPR84. ${ }^{18}$

Chemistry. All target compounds were synthesized by coupling of the 6-chlorouracil derivative 12 or 13 with the appropriate amines. The commercially available barbituric acid 9 was converted to 2,4,6-trichloropyrimidine (10) by treatment with phosphorus oxychloride in the presence of dimethylaniline. The key intermediate 6-chlorouracil (11) was obtained by heating 10 to reflux with aqueous sodium hydroxide solution. 6Chloro-1-methyluracil (12a) and 6-chloro-3-methyluracil (12b) 
Table 2. Agonistic Activity of 6-Arylalkylamino-Substituted Uracil Derivatives

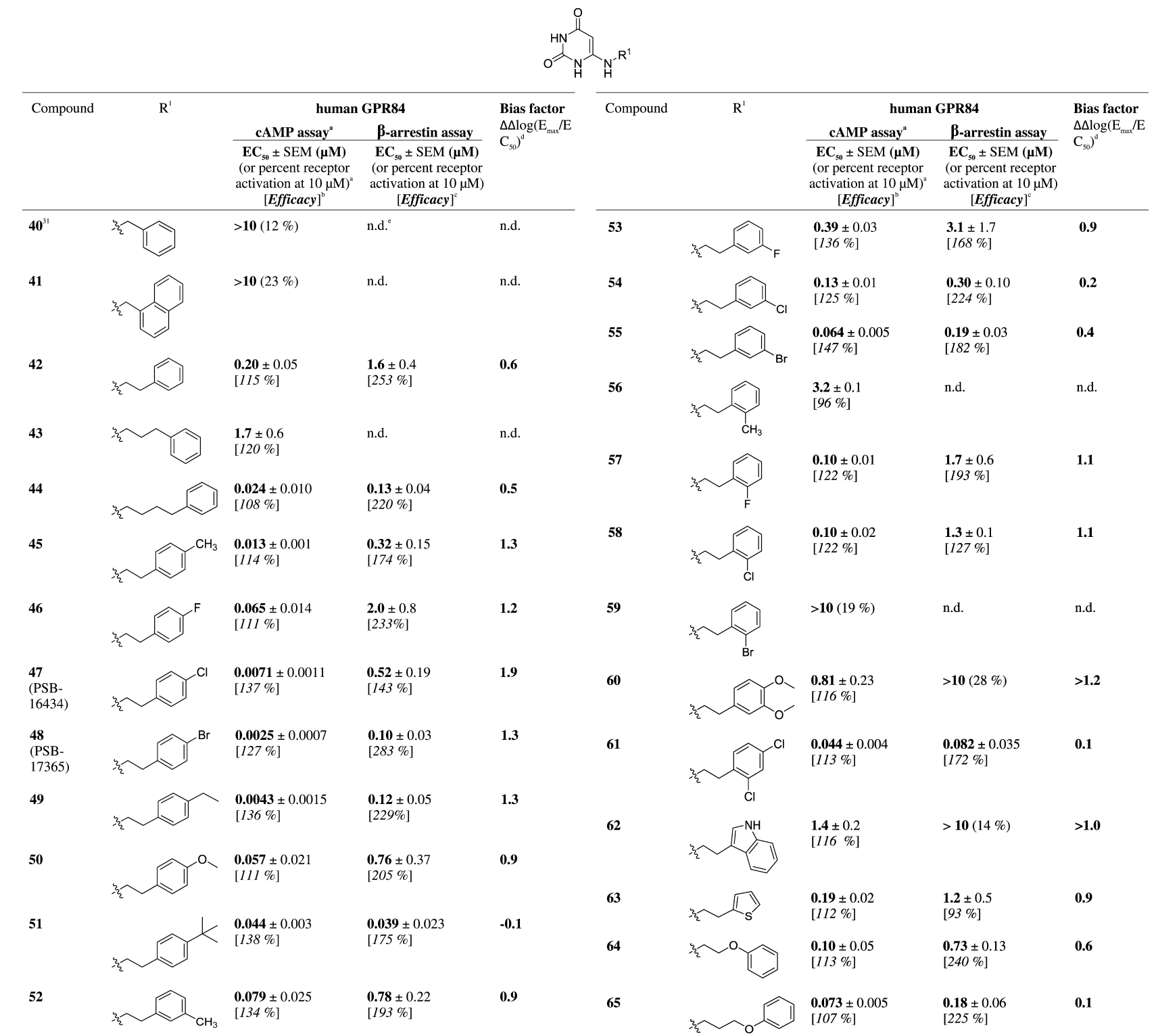

${ }^{a}$ Inhibition of forskolin $(10 \mu \mathrm{M})$-induced decrease in cAMP accumulation. ${ }^{b}$ Efficacy $\left(E_{\max }\right)$ relative to the max. effect of decanoic acid $(100 \mu \mathrm{M})$ $(=100 \%) .{ }^{c}$ Efficacy $\left(E_{\max }\right)$ relative to the max. effect of embelin $(10 \mu \mathrm{M})(=100 \%) .{ }^{d}$ Bias factor was calculated as described in Experimental Section. $e_{\text {n.d., not determined. }}$

were synthesized by treatment of $\mathbf{1 1}$ with methyl iodide in the presence of potassium carbonate, followed by silica gel column chromatography using methanol (1\%) in dichloromethane. 1,3Dimethyl-6-chlorouracil (12c) was synthesized by treating 11 with an excess of methyl iodide. Finally, 6-chlorouracils 12a-c and 5-bromouracil 13, respectively, were treated with the appropriate amine in 1-butanol under reflux overnight to produce the desired products 4 and 14-71. Bromination was achieved by treatment of the appropriate uracil derivative with $N$ bromosuccinimide (NBS) to yield 72-75, whereas reacting 6, $20,21,42$, or 43 with sodium nitrite under acidic conditions led to the 5-nitrosouracil derivatives 76-80. The structures of all synthesized final products were confirmed by ${ }^{1} \mathrm{H}$ and ${ }^{13} \mathrm{C} \mathrm{NMR}$, or attached proton test $\left({ }^{13} \mathrm{C}_{\text {apt }}\right)$ NMR spectroscopy. The purity of the compounds was determined by high-performance liquid chromatography (HPLC) coupled to UV and electrospray ionization mass spectrometry (ESI-MS), confirming a purity of at least 95\% (Scheme 1).

\section{PHARMACOLOGICAL EVALUATION}

All synthesized compounds were initially investigated in cAMP accumulation assays at a concentration of $10 \mu \mathrm{M}$ for their potency to inhibit forskolin $(10 \mu \mathrm{M})$-induced cAMP accumulation. Chinese hamster ovary $(\mathrm{CHO})$ cells stably expressing the $\mathrm{G}_{\mathrm{i}}$ protein-coupled human GPR84 were employed. Full concentration-response curves were determined, and $\mathrm{EC}_{50}$ values were calculated for compounds that showed more than $50 \%$ inhibition of cAMP accumulation in preliminary tests (see Tables 1-3). Efficacy of the compounds was determined by comparing their maximal effects to the maximal signal induced by decanoic acid $\left(100 \mu \mathrm{M} ; \mathrm{EC}_{50} 7.42 \mu \mathrm{M}\right)$. Standard GPR84 agonists were tested under the same conditions for comparison (see Table 1). Selected compounds that did not activate the 
receptor were screened in antagonist assays versus decanoic acid $(20 \mu \mathrm{M})$ at a concentration of $10 \mu \mathrm{M}$. GPR84 specificity of the observed effects was confirmed for the most potent compounds by testing them in the same assay, but in nontransfected $\mathrm{CHO}$ cells lacking GPR84 expression. Selected compounds were also investigated in $\beta$-arrestin 2 recruitment assays using the $\beta$ galactosidase fragment complementation technology (PathHunter, DiscoverX) ${ }^{28,29}$ (see Tables 1-3). Potent GPR84 agonists were additionally studied at human free fatty acid receptors FFAR1 and FFAR4 to explore their selectivity (see Tables S1 and S2). ${ }^{26}$

\section{STRUCTURE-ACTIVITY RELATIONSHIPS}

CAMP Accumulation Assays. Previously, 6-octylaminouracil (4) was identified as a GPR84 agonist displaying an $\mathrm{EC}_{50}$ value of $512 \mathrm{nM}$ determined in $\left[{ }^{35} \mathrm{~S}\right] \mathrm{GTP} \gamma \mathrm{S}$ binding assays using Sf9 cell membranes expressing a human GPR84-G $\alpha_{\mathrm{i}}$ fusion protein. ${ }^{8}$ This relatively high $\mathrm{EC}_{50}$ value may be due to the highly artificial test system that was employed. In our cAMP accumulation assay using $\mathrm{CHO}$ cells transfected with the human GPR84, 4 induced an inhibition of forskolin-induced cAMP accumulation with an $\mathrm{EC}_{50}$ value of $17 \mathrm{nM}$ (see Figure 6). It was about 440 -fold more potent than the standard agonist decanoic acid $\left(\mathrm{EC}_{50} 7400 \mathrm{nM}, p=0.0003\right)$. We confirmed that the effect seen with 4 in the cAMP assay was clearly due to GPR84 activation as it had no effect in nontransfected CHO cells (see Figure 4).

To gain deeper insights into the SARs of uracil derivatives as agonists of GPR84, we initially focused on modifying the hydrophobic alkyl tail: a change in alkyl chain length ranging from $\mathrm{C} 1$ to $\mathrm{C} 7$ and $\mathrm{C} 9$ to $\mathrm{C} 10$ (see Table 1) demonstrated that the right alkyl chain length was essential for high potency of the compounds at GPR84. A short chain length of $\mathrm{C} 2-3$ as in 13 and 14, as well as a branched alkyl chain as in 15-18, yielded inactive uracil derivatives, whereas 19 with an alkyl chain length of five carbon atoms displayed moderate agonistic activity with an $\mathrm{EC}_{50}$ of $460 \mathrm{nM}$. Increasing the chain length by one more methylene unit to hexyl (20) led to a highly potent agonist displaying an $\mathrm{EC}_{50}$ value of $5.0 \mathrm{nM}, 92$-fold more potent than $19(p=0.0391)$. Further extension of the alkyl chain length to C7 (21, EC 5012 $\mathrm{nM})$, C9 $\left(22, \mathrm{EC}_{50} 30 \mathrm{nM}\right)$, or C10 (23, $\left.\mathrm{EC}_{50} 21 \mathrm{nM}\right)$ led to slightly reduced activities. Branching of the alkyl chain as in $\mathrm{N}^{6}$ $(R, S)$-(2-ethyl)hexyluracil (24) abolished activity, indicating limited space. $N^{6}$-Methylthiopropyluracil $\left(26, \mathrm{EC}_{50} 23000 \mathrm{nM}\right)$, an analogue of $N^{6}$-pentyluracil $\left(19, \mathrm{EC}_{50} 460 \mathrm{nM}\right)$, in which a methylene group was exchanged for a (lipophilic) sulfur atom, was surprisingly 50 -fold less potent than 19 . The rank order of potency for the length of the alkyl chain attached to the uracil core was as follows: $\mathrm{C} 6\left(20, \mathrm{EC}_{50} 5.0 \mathrm{nM}\right.$, vs $\left.4, p=0.0185\right) \geq \mathrm{C} 7$ $\left(21, \mathrm{EC}_{50} 12 \mathrm{nM}\right) \geq \mathrm{C} 8\left(4, \mathrm{EC}_{50} 17 \mathrm{nM}\right) \geq \mathrm{C} 10\left(23, \mathrm{EC}_{50} 21\right.$ $\mathrm{nM}) \geq \mathrm{C} 9\left(22, \mathrm{EC}_{50} 30 \mathrm{nM}\right)>\mathrm{C} 5\left(19, \mathrm{EC}_{50} 460 \mathrm{nM}, p=\right.$ $0.0268)$. Next, polar groups such as hydroxy or carboxy were introduced at the end of the alkyl chain yielding compounds 27 , 28 or $29, \mathbf{3 0}$. Among them, only the hydroxyheptyl derivative $\mathbf{2 8}$ $\left(\mathrm{EC}_{50} 2000 \mathrm{nM}\right)$ showed moderate activity; its potency was significantly decreased in comparison to the lead compound 4 ( $p$ $=0.0130$ ); the other polar derivatives were all inactive, again indicating that a highly lipophilic pocket harbored the alkyl chain.

Our next effort was to investigate the importance of the $\mathrm{NH}$ functions, N1-H, N3-H, and $\mathrm{N}^{6}-\mathrm{H}$ of the 6-aminouracil derivatives. Methylation of N3 reduced the agonistic potency by more than 40-fold (compare $31\left(\mathrm{EC}_{50} 720 \mathrm{nM}\right)$ with $4\left(\mathrm{EC}_{50} 17\right.$ $\mathrm{nM}, 42$-fold difference), $32\left(\mathrm{EC}_{50} 2000 \mathrm{nM}\right)$ with $22\left(\mathrm{EC}_{50} 30\right.$
$\mathrm{nM}$, 67-fold difference), and $33\left(\mathrm{EC}_{50} 1900 \mathrm{nM}\right)$ with $23\left(\mathrm{EC}_{50}\right.$ $21 \mathrm{nM}, 90$-fold difference)). Methylation of N1 (34-35) or N1,N3-dimethylation (36) virtually abolished potency of the compounds. Thus, both $\mathrm{NH}$ atoms are important and may serve as hydrogen bond donors, with $\mathrm{N} 1-\mathrm{H}$ being more important than the $\mathrm{N} 3-\mathrm{H}$ atom. Substitution of the hydrogen atom at the 6-amino group $\left(\mathrm{N}^{6}-\mathrm{H}\right)$ of the uracil core with a methyl group also led to a reduction in potency of the hexyl-substituted derivative (compare $37\left(\mathrm{EC}_{50} 110 \mathrm{nM}\right)$ with $20\left(\mathrm{EC}_{50} 5.0 \mathrm{nM}\right)$, 22 -fold reduction). However, surprisingly, $\mathrm{N}^{6}$-methylation of the octyl-substituted lead structure 4 only led to an insignificant (2fold) decrease in potency (compare $38\left(\mathrm{EC}_{50} 38 \mathrm{nM}\right)$ with 4 $\left.\left(\mathrm{EC}_{50} 17 \mathrm{nM}\right)\right)$. Taken together, these studies suggest that all $\mathrm{NH}$ functions in the 6-aminouracil derivatives, $\mathrm{N} 1-\mathrm{H}, \mathrm{N} 3-\mathrm{H}$, and $\mathrm{N}^{6}-\mathrm{H}$, should be ideally unsubstituted, but a free $\mathrm{NH}$ function appears to be particularly important at the N1-position.

Next, we moved the octylamino substituent of lead compound 4 from the 6- to the 5-position of the uracil core, resulting in 39, which turned out to be completely inactive $\left(\mathrm{EC}_{50}>10 \mu \mathrm{M}\right)$. This confirms that the position of the hydrophobic tail is very important for its interaction with the receptor.

Subsequently, we introduced a large variety of aromatic residues attached to the $\mathrm{N}^{6}$-alkyl chain (see Table 2). Benzyl (40) and (1-naphthyl)methyl substitution (41) led to inactive compounds, whereas longer alkyl or alkoxy linkers of two to four atoms between $\mathrm{N}^{6}$ of the aminouracil core and the aromatic ring resulted in moderately to highly potent GPR84 agonists. A phenylethyl substituent led to moderate activity (42, EC $_{50} 200$ $\mathrm{nM})$. Further elongation of the carbon chain in the phenylpropyl derivative 43 reduced activity by 9-fold ( $\left.\mathrm{EC}_{50} 1700 \mathrm{nM}\right)$; however, an additional methylene group (in the phenylbutyl derivative 44, $\mathrm{EC}_{50} 24 \mathrm{nM}$ ) dramatically increased potency to a value similar to that determined for the octyl-substituted lead structure 4. The lipophilic chains of both compounds, 4 and 44, have about the same length. Encouraged by these results, our next effort was to introduce substituents on the phenyl ring of the relatively potent phenylethyl-substituted compound $\mathbf{4 2}$ with the goal to improve its potency. The following substituents were introduced at the $p$-position of the phenyl ring: $p$-methyl (45, $\left.\mathrm{EC}_{50} 13 \mathrm{nM}\right), p$-fluoro $\left(46, \mathrm{EC}_{50} 65 \mathrm{nM}\right)$, p-chloro $\left(47, \mathrm{EC}_{50} 7.1\right.$ $\mathrm{nM})$, $p$-bromo $\left(48, \mathrm{EC}_{50} 2.5 \mathrm{nM}\right)$, $p$-ethyl (49, $\left.\mathrm{EC}_{50} 4.3 \mathrm{nM}\right), p$ methoxy (50, $\left.\mathrm{EC}_{50} 57 \mathrm{nM}\right)$, and p-tert-butyl (51, $\left.\mathrm{EC}_{50} 44 \mathrm{nM}\right)$. The obtained results showed that the substituents led to an increase in potency, and hydrophobic residues were particularly favorable. For example, the bulky $p$-bromo substituent in $\mathbf{4 8}$ displayed a 23-fold increased potency compared to the corresponding $p$-methoxy derivative 50, and in fact, $48\left(\mathrm{EC}_{50}\right.$ $2.5 \mathrm{nM}$ ) was the most potent GPR84 agonist of the present series. The rank order of potency for substituents at the $p$ position of the phenyl ring in $\mathrm{N}^{6}$-phenethyluracil derivatives was as follows: $p$-bromo $\left(48, \mathrm{EC}_{50} 2.5 \mathrm{nM}\right) \geq$ p-ethyl $\left(49, \mathrm{EC}_{50} 4.3\right.$ $\mathrm{nM}) \geq p$-chloro $\left(47, \mathrm{EC}_{50} 7.1 \mathrm{nM}\right)>p$-methyl $\left(45, \mathrm{EC}_{50} 13 \mathrm{nM}\right.$, $p=0.0166)>p$-tert-butyl $\left(51, \mathrm{EC}_{50} 44 \mathrm{nM} ; p=0.0008\right) \geq p$ methoxy $\left(50, \mathrm{EC}_{50} 57 \mathrm{nM}\right) \geq p$-fluoro $\left(46, \mathrm{EC}_{50} 65 \mathrm{nM}\right) \geq \mathrm{p}$ unsubstituted (42, $\left.\mathrm{EC}_{50} 200 \mathrm{nM}\right)$.

Subsequently, the effects of substituents at the $o$ - or $m$-position of the phenyl moiety were investigated. The results showed that substituents in these positions generally reduced potency compared to compounds with substituents at the p-position. The rank order of potency for substituents at the m-position of the phenyl ring in $\mathrm{N}^{6}$-phenethyluracil derivatives was as follows: $m$-bromo $\left(55, \mathrm{EC}_{50} 64 \mathrm{nM}\right) \geq m$-methyl $\left(52, \mathrm{EC}_{50} 79 \mathrm{nM}\right) \geq o$ fluoro $\left(57, \mathrm{EC}_{50} 100 \mathrm{nM}, p=0.0299\right.$ compared to 55) $=o$-chloro 
$\left(58, \mathrm{EC}_{50} 100 \mathrm{nM}\right) \geq m$-chloro $\left(54, \mathrm{EC}_{50} 130 \mathrm{nM}\right) \geq \mathrm{o}, \mathrm{m}$ unsubstituted $\left(42, \mathrm{EC}_{50} 200 \mathrm{nM}\right)>m$-fluoro $\left(53, \mathrm{EC}_{50} 390 \mathrm{nM}\right.$, $p=0.0007$ vs 54) > o-methyl (56, $\mathrm{EC}_{50} 3200 \mathrm{nM}, p<0.0001$ vs 53) $\gg o$-bromo (59, $\left.\mathrm{EC}_{50}>10000 \mathrm{nM}\right)$. m-Methoxy substitution was not well tolerated as demonstrated by the moderate potency of the $m, p$-dimethoxyphenyl derivative 60 $\left(\mathrm{EC}_{50} 810 \mathrm{nM}\right.$, compared to that of the $p$-methoxy derivative 50, $\left.\mathrm{EC}_{50} 57 \mathrm{nM}, p=0.0327\right)$. Dichloro substitution in the $\mathrm{m}$ - and $\mathrm{p}$ positions $\left(61, \mathrm{EC}_{50} 44 \mathrm{nM}\right)$ combined the positive effect of the $p$ chloro substituent and the negative effect of the $m$-chloro substituent. Bioisosteric replacement of the phenyl ring in $\mathbf{4 2}$ $\left(\mathrm{EC}_{50} 200 \mathrm{nM}\right)$ with a 2-thienyl ring $\left(63, \mathrm{EC}_{50} 190 \mathrm{nM}\right)$ was well tolerated, whereas exchange for a 3-indolyl residue significantly decreased potency $\left(62, \mathrm{EC}_{50} 1400 \mathrm{nM}, p=0.0052\right)$. Introducing an ether linkage into the side chain to increase polarity was well tolerated (compare the phenoxypropyl derivative 65, $\mathrm{EC}_{50} 73$ $\mathrm{nM}$, with its phenylbutyl analog $44, \mathrm{EC}_{50} 24 \mathrm{nM}$ ) and even led to 17 -fold enhanced potency in case of the phenoxyethyl derivative $64\left(\mathrm{EC}_{50} 100 \mathrm{nM}\right)$ compared to the analogous phenylpropyl derivative 43 (1700 $\mathrm{nM})$.

In a next small series of compounds, we rigidified the $\mathrm{N}^{6}$ substitutent by integrating the 6-amino group into cyclic structures, piperidine or piperazine (see Table 3). The 4phenylpiperidinyl derivative 66 was inactive, whereas the corresponding, somewhat more flexible, 4-benzylpiperidinylsubstituted compound $67\left(\mathrm{EC}_{50} 130 \mathrm{nM}\right)$ was equipotent to the $\mathrm{N}^{6}$-phenylethyl-substituted analogue 42 and 13 -fold more potent than the $\mathrm{N}^{6}$-phenylpropyl-substituted compound 43. Four 6piperazinyluracil derivatives were obtained, which were substituted on the free piperazine $\mathrm{N}$-atom $(68-71)$. All four compounds showed submicromolar potency with $\mathrm{IC}_{50}$ values between 38 and $150 \mathrm{nM}$, indicating that various residues are tolerated ranging from substituted phenyl $(68,69)$ to indanyl (70) and even to (1-naphthyl)methyl (71).

Finally, we investigated the effect of substituting the uracil 5position of 5-(ar)alkylaminouracil derivatives (72-80, Table 3). We selected potent agonists discussed above $(4,20,21,42,43$, and 48) and introduced a bromo or nitroso substituent at position 5 . The resulting derivatives showed only moderate to weak potency compared to their parent compounds (compare for 5-bromo substitution 72 vs 20 (1500-fold difference, $p=$ $0.0094), 73$ vs 4 ( 119 -fold difference, $p=0.0287)$, 74 vs 48 (148fold difference, $p<0.00001$ ), and 75 vs 43 (>6-fold difference) and for 5-nitroso substitution 76 vs 20 (1570-fold difference, $p=$ 0.0001 ), 77 vs 21 (40-fold difference, $p=0.0006), 78$ vs 4 (36fold difference, $p=0.0022$ ), and 79 vs 42 ( $>51$-fold difference, $p$ $<0.0001)$ ).

Selected compounds that were inactive as agonists were subsequently tested for potential blockade of the receptor in cAMP assays. However, none of them was found to be an antagonist of GPR84 (data not shown).

The $\mathrm{N}^{6}$-substituted 1,3-dimethyl-6-aminouracil derivative uradipil (see Table 1), an $\alpha 1$-adrenoreceptor antagonist and serotonin $5-\mathrm{HT}_{1 \mathrm{~A}}$ receptor agonist, which is therapeutically used as an antihypertensive drug in Europe, neither activated nor inhibited GPR84 as determined in cAMP accumulation assays.

Figure 3 summarizes the structure-activity relationships of the investigated compounds as agonists of the human GPR84: (i) the length of the alkyl chain plays an important role in determining the potency; an optimal chain length of six carbon atoms was determined. Introducing an aromatic residue into the alkyl chain was well tolerated and in some cases led to increased potency. However, branching of the alkyl chain or attachment of polar
Table 3. Various 6-Substituted and 5,6-Disubstituted Uracil Derivatives

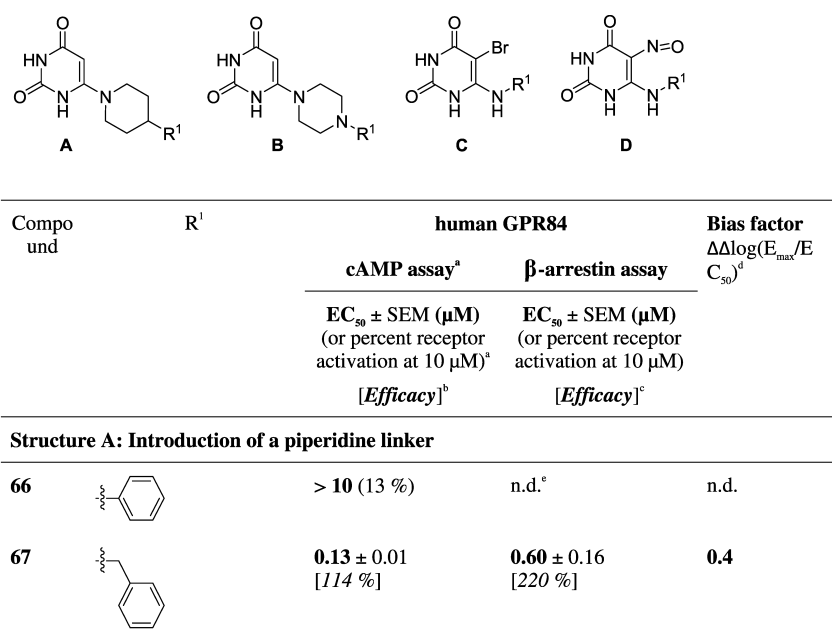

\begin{tabular}{|c|c|c|c|}
\hline \multicolumn{4}{|c|}{ Structure B: Introduction of a piperazine linker } \\
\hline 68 & $\begin{array}{l}\mathbf{0 . 1 5} \pm 0.01 \\
{[117 \%]}\end{array}$ & $\begin{array}{l}\mathbf{1 . 8} \pm 0.2 \\
{[120 \%]}\end{array}$ & 1.1 \\
\hline $69^{32}$ & $\begin{array}{l}\mathbf{0 . 0 3 8} \pm 0.007 \\
{[53 \%]}\end{array}$ & n.d. & n.d. \\
\hline 70 & $\begin{array}{l}\mathbf{0 . 0 6 0} \pm 0.005 \\
{[164 \%]}\end{array}$ & n.d. & n.d. \\
\hline 71 & $\begin{array}{l}\mathbf{0 . 1 5} \pm 0.04 \\
{[137 \%]}\end{array}$ & n.d. & n.d. \\
\hline
\end{tabular}

\begin{tabular}{|c|c|c|c|}
\hline \multicolumn{4}{|c|}{ Structure C: 5-Bromo-substituted uracil derivatives } \\
\hline 72 & $\begin{array}{l}7.4 \pm 1.6 \\
{[123 \%]}\end{array}$ & n.d. & n.d. \\
\hline 73 & $\begin{array}{l}\mathbf{2 . 0} \pm 0.6 \\
{[114 \%]}\end{array}$ & n.d. & n.d. \\
\hline 74 & $\begin{array}{l}\mathbf{0 . 3 7} \pm 0.02 \\
{[114 \%]}\end{array}$ & $\begin{array}{l}6.7 \pm 1.8 \\
{[163 \%]}\end{array}$ & 1.2 \\
\hline 75 & $>10(15 \%)$ & n.d. & n.d. \\
\hline
\end{tabular}

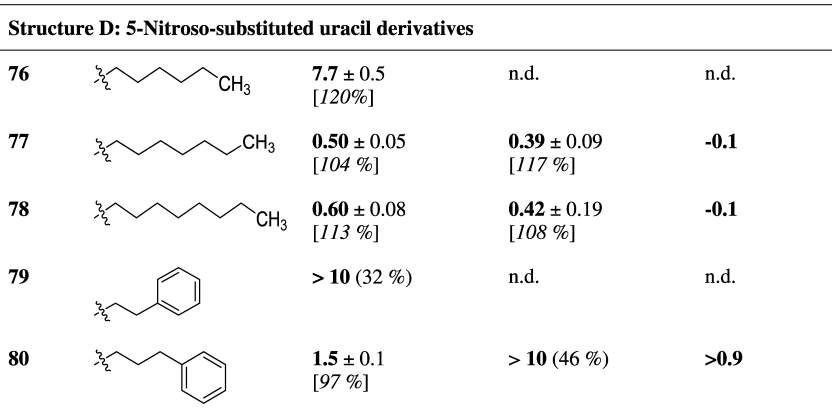

${ }^{a}$ Inhibition of forskolin $(10 \mu \mathrm{M})$-induced decrease in cAMP accumulation. ${ }^{b}$ Efficacy $\left(E_{\max }\right)$ relative to the max. effect of decanoic acid $(100 \mu \mathrm{M})(=100 \%) .{ }^{c}$ Efficacy $\left(E_{\max }\right)$ relative to the max. effect of embelin $(10 \mu \mathrm{M})(=100 \%) .{ }^{d}$ Bias factor was calculated as described in Experimental Section. ${ }^{e}$ n.d., not determined.

groups $(-\mathrm{OH}$ or $-\mathrm{COOH})$ at its terminus reduced or abolished the activity; (ii) free $\mathrm{N} 3-\mathrm{H}$ and particularly $\mathrm{N} 1-\mathrm{H}$ functions in the uracil core structure were found to be very important for activity; (iii) the substitution at the 6-position of uracil was crucial, whereas 5-substitution abolished the activity. 


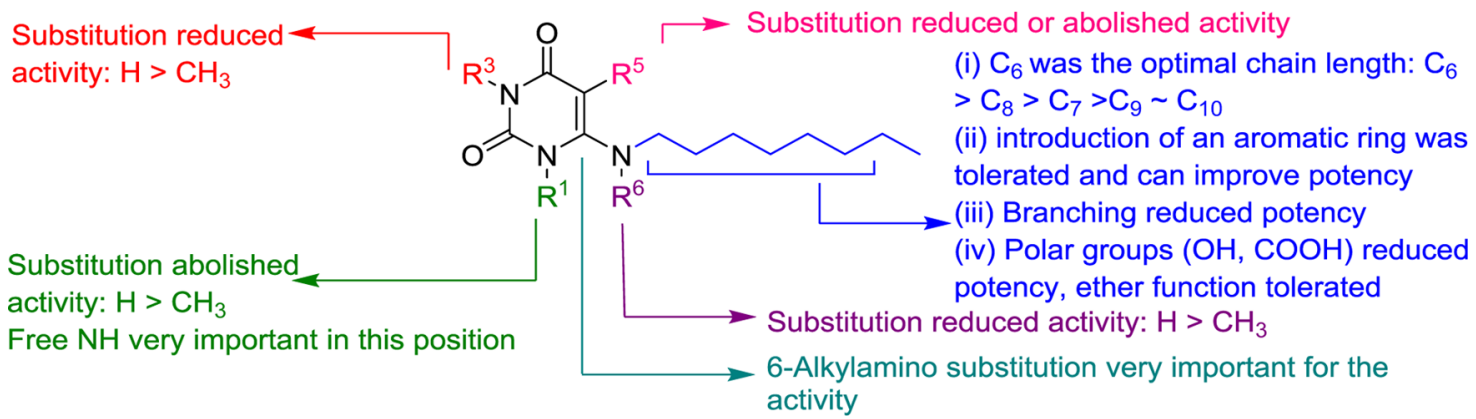

Figure 3. Structure-activity relationships of uracil derivatives at human GPR84 as determined in cAMP assays.

Efficacy in cAMP Assays. The maximal effect of the physiological agonist decanoic acid (1) was set at $100 \%$ and compared to the maximal effects observed for the investigated uracil derivatives (see Tables 1-3). Lead structure 4 displayed a similar efficacy (104\%), and most of the potent uracil derivatives showed the same or even higher efficacy. For example, the most potent agonists 20, 47, and 48 had efficacies of $127-137 \%$. Our results showed that potent uracil-derived GPR84 agonists fully activate the $G_{i}$ protein-coupled pathway.

Specificity of Effects Determined in cAMP Accumulation Assays. Selected potent GPR84 agonists, namely, 20, 47, 48,49 , as well as the lead compound 4 , were investigated for their ability to inhibit forskolin-induced cAMP accumulation in $\mathrm{CHO}$ wild-type (wt) cells, which do not express GPR84. None of the tested compounds showed any significant effect at concentrations of up to $1 \mu \mathrm{M}$. At high concentrations of up to $100 \mu \mathrm{M}, 4$ and 20 showed no effect, whereas the other investigated compounds induced a minor inhibition, which never exceeded $50 \%$ at a very high concentration of $100 \mu \mathrm{M}$ (Figure 4). This indicates that the effects measured in cAMP assays on GPR84transfected cells (Tables 1-3) were clearly due to GPR84 activation.

$\boldsymbol{\beta}$-Arrestin Recruitment Assays. Selected agonists that had shown potency in the cAMP assays were further evaluated in $\beta$ arrestin recruitment assays using the $\beta$-galactosidase comple-

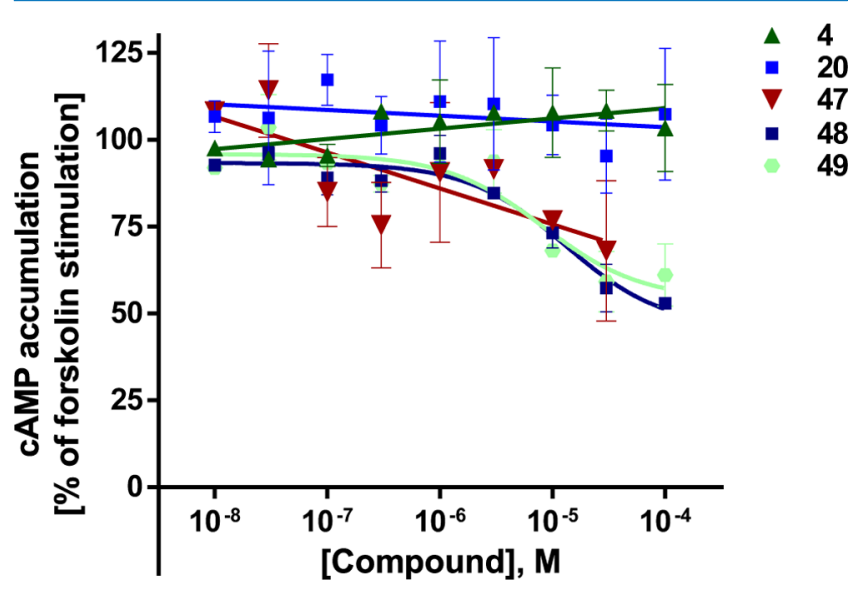

Figure 4. Evaluation of selected compounds at wild-type (wt) $\mathrm{CHO}$ cells in cAMP accumulation assays. $\mathrm{CHO}$ wt cells were preincubated with the respective test compounds at the indicated concentrations for 5 $\min$. Then, $10 \mu \mathrm{M}$ forskolin was added and the cells were incubated for additional $15 \mathrm{~min}$. The maximal forskolin-induced cAMP accumulation in the absence of test compound stimulation was defined as $100 \%$. Mean values \pm standard error of the mean (SEM) from three independent experiments performed in duplicates are shown. mentation assay technology (DiscoverX) (see Tables $1-3$ and Figure $6 \mathrm{~B}, \mathrm{D})$. The standard agonist embelin (6, Figure 1) was used in these assays as a reference compound. Embelin is more suitable than decanoic acid (1) because it is more potent and has a somewhat higher efficacy in the $\beta$-arrestin assays than the physiological standard agonist 1 . Both lipidic agonists, embelin and decanoic acid, were unbiased, showing nearly identical $\mathrm{EC}_{50}$ values in the two different assays (decanoic acid: 7420 and 6080 $\mathrm{nM}$, respectively; embelin: 795 and $424 \mathrm{nM}$, respectively; see Table 1). In contrast, lead structure $\mathbf{4}$ and the structurally related (hexylthio)pyrimidine-4,6-diol (5) were nearly 7- to 10-fold more potent in the $\mathrm{G}_{\mathrm{i}}$-dependent cAMP assay compared to the $\beta$ arrestin recruitment assay $(4,17$ vs $110 \mathrm{nM} ; 5,6.6$ vs $78 \mathrm{nM})$. As a direct comparison of $\mathrm{EC}_{50}$ values obtained in different assays may be misleading due to different degrees of signal amplification, we calculated the bias factors. The Hill slope of the curves was in most cases close to 1 , between 0.9 and 1.3 . Because both assays were conducted in the same cellular background, the reference compound will control for any systematic bias. ${ }^{33}$ For each of the two intracellular pathways, $\Delta \log \left(E_{\max } / \mathrm{EC}_{50}\right)$ was computed, followed by calculating the pathway bias factor as $\Delta \Delta \log \left(E_{\max } / \mathrm{EC}_{50}\right)$ according to a recently described and validated method. ${ }^{33}$ A bias factor of 0 means no bias, whereas a factor of 1 corresponds to a 10 -fold preference, and a factor of 2 to a 100 -fold selectivity for the $\mathrm{G}_{\mathrm{i}}$-coupled pathway. For many compounds, we observed an ca. 8- to 20-fold preference for the cAMP pathway (bias factor of $0.9-1.3$ ) compared to $\beta$-arrestin recruitment. Nevertheless, the SARs of the uracil derivatives determined in $\beta$-arrestin assays were quite similar to those observed in cAMP assays (see Figure 5). Among the tested compounds, three very potent unbiased agonists could be identified, revealing almost identical $\mathrm{EC}_{50}$ values in both assays (see Figures 5 and 6A,B): 20, $\mathrm{EC}_{50}$ cAMP $5.0 \mathrm{nM}, \beta$ arrestin $3.2 \mathrm{nM}$, bias factor: $0.0 ; 22, \mathrm{EC}_{50}$ cAMP $30.0 \mathrm{nM}, \beta$ arrestin $34.0 \mathrm{nM}$ (bias factor: 0.0 ); 51, $\mathrm{EC}_{50} \mathrm{CAMP} 44.0 \mathrm{nM}, \beta$ arrestin $39.0 \mathrm{nM}$ (bias factor -0.1). The unbiased compound 20 with a $\mathrm{C}_{6}$ alkyl tail was the most potent agonist of the present series in the $\beta$-arrestin assay. The rank order of potency in the $\beta$ arrestin assay with regard to the length of the alkyl chain at the uracil core was as follows: C6 $(\mathbf{2 0}, 3.2 \mathrm{nM})>\mathrm{C} 9\left(\mathbf{2 2}, \mathrm{EC}_{50} 34\right.$ $\mathrm{nM}, p=0.0113) \geq \mathrm{C} 8\left(4, \mathrm{EC}_{50} 110 \mathrm{nM}\right)>\mathrm{C} 10\left(23, \mathrm{EC}_{50} 360\right.$ $\mathrm{nM}, p=0.0033) \approx \mathrm{C} 7\left(21, \mathrm{EC}_{50} 390 \mathrm{nM}\right)>\mathrm{C} 5\left(19, \mathrm{EC}_{50} 4800\right.$ $\mathrm{nM}, p=0.0292)$. A compound with a polar hydroxy group at the end of the lipophilic tail exhibited identical potency in both assay systems (28, $\mathrm{EC}_{50} 1980$ vs $2120 \mathrm{nM}$, bias factor: -0.2). In contrast, compounds $37\left(\mathrm{EC}_{50} 110 \mathrm{nM}\right.$ (cAMP) vs $4200 \mathrm{nM}(\beta$ arrestin $))$ and $38\left(\mathrm{EC}_{50} 38 \mathrm{nM}\right.$ (cAMP) vs $640 \mathrm{nM}(\beta$-arrestin $\left.)\right)$ displayed bias factors of 1.2 and 0.6 , respectively. The most biased agonists displaying a bias factor $\left(\Delta \Delta \log \left(E_{\max } / \mathrm{EC}_{50}\right)\right) \geq$ 
A

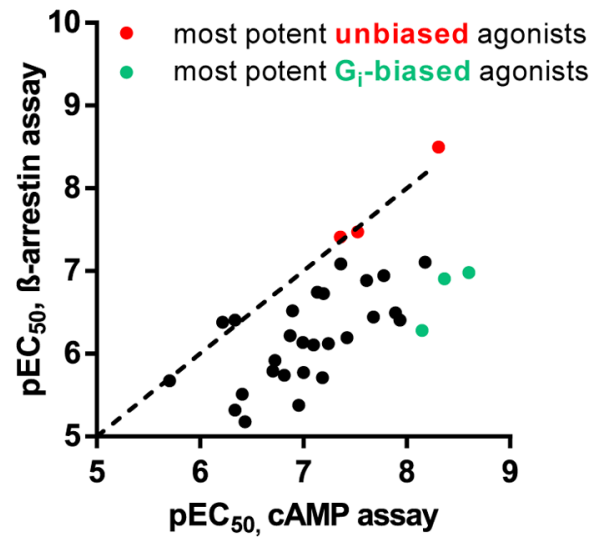

B

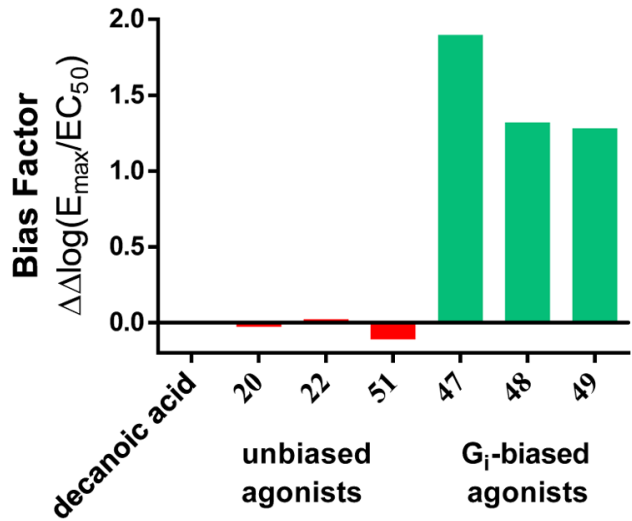

Figure 5. (A) Correlation between the $\mathrm{pEC}_{50}$ values determined in cAMP assays and $\mathrm{pEC}_{50}$ values determined in $\beta$-arrestin assays. (Number of pairs: 34; $p$ value $($ two-tailed $)=0.0008$ ). The most potent unbiased GPR84 agonists 20, 22, and $\mathbf{5 1}$ are marked in red; the most potent $\mathrm{G}_{\mathrm{i}}$-biased agonists $\mathbf{4 7}$, 48, and 49 are marked in turquois. (B) Bias factors $\left[\Delta \Delta \log \left(E_{\max } / \mathrm{EC}_{50}\right)\right]$ calculated for the most potent biased and unbiased GPR84 agonists; positive values indicate bias for the $\mathrm{G}_{\mathrm{i}}$ protein-dependent over $\beta$-arrestin recruitment pathway.

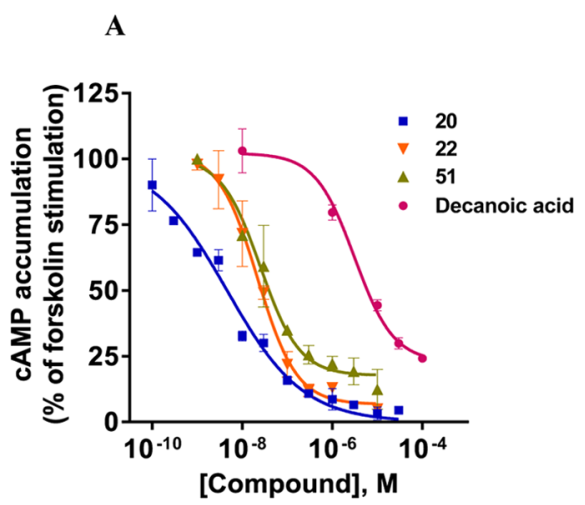

C

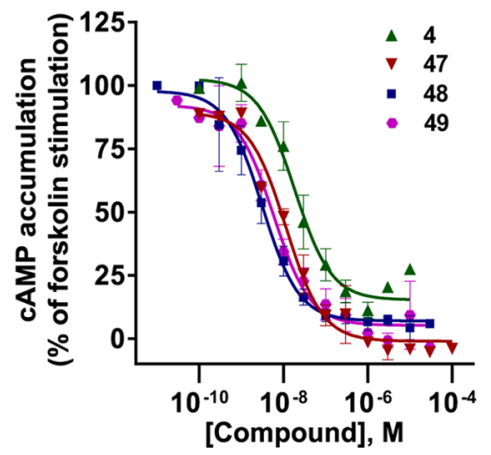

B

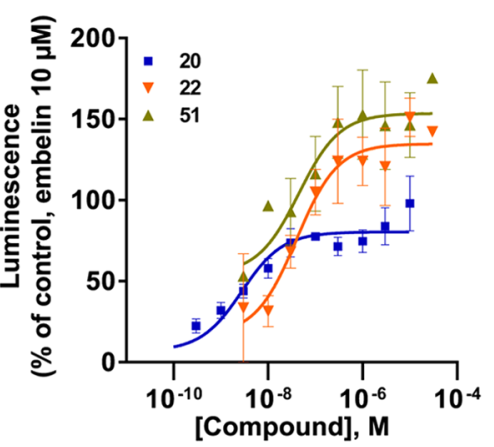

D

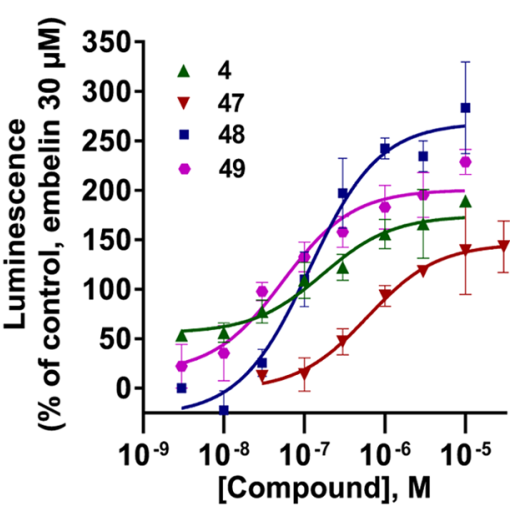

Figure 6. Concentration-response curves of selected compounds at human GPR84 in cAMP assays (A, C) and in enzyme fragment complementation $\beta$-arrestin recruitment assays $(\mathrm{B}, \mathrm{D})$. Mean values $\pm \mathrm{SEM}$ from three to four independent experiments performed in duplicates are shown. For $\mathrm{EC}_{50}$ values, see Tables 1 and 2 .

1.3 and an $\mathrm{EC}_{50}<10 \mathrm{nM}$ were 47, 48, and 49 (Figure 6), all of which represent p-substituted 6-(phenylethylamino)uracil derivatives. The most pathway-selective agonist of the whole series was 47 with an $\mathrm{IC}_{50}$ value in the cAMP assay of $7.1 \mathrm{nM}$ and a bias factor of 1.9 corresponding to a 79-fold preference for $G_{i}$ coupling versus $\beta$-arrestin recruitment (see Figure $5 \mathrm{~B}$ ).

Concentration-response curves for selected agonists including the lead structure 4 are depicted in Figure 6A-D.
Efficacy in $\boldsymbol{\beta}$-Arrestin Assays. The maximal effect of embelin (6) in the $\beta$-arrestin assays was set at $100 \%$ efficacy. Decanoic acid (1) was slightly less efficacious (92\%), whereas lead structure 4 showed a higher efficacy of $189 \%$. Most of the potent uracil derivatives displayed high efficacies of around 150$250 \%$, with a few exceptions. Particularly high efficacy was observed for the $\mathrm{N}^{6}$-methylated 6-aminouracil derivatives 37 (278\%) and 38 (309\%) and 6-( $p$-bromophenethylamino)uracil $(48,283 \%)$, whereas the 6-alkylaminouracil derivatives 20,23 , 

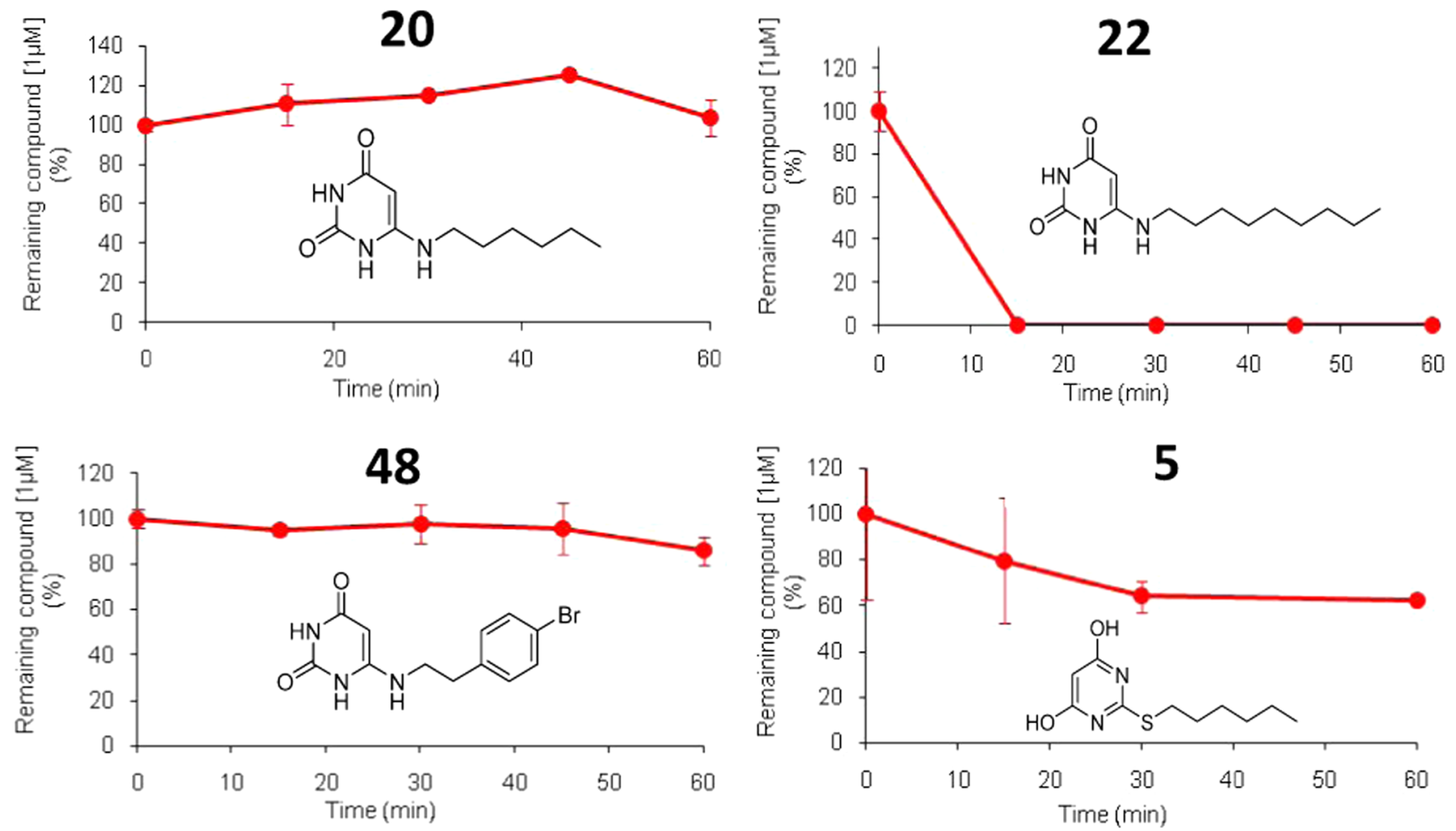

Figure 7. Metabolic stability of 6-aminouracil derivatives 20, 22, and 48, and 2-hexylthiopyrimidine-4,6-diol (5) in human liver microsomes (0.5 mg/ $\mathrm{mL}$, mixed gender, pooled). Compounds were tested at a concentration of $1 \mu \mathrm{M}$. Data points represent mean values \pm SD (for details, see Experimental Section).

77, and 78 showed efficacies of only around 100\%. For comparison, the previously published GPR 84 agonist 5 displayed a high efficacy of $242 \%$. The availability of compounds with a range of efficacies in $\beta$-arrestin assays will be useful to study its pharmacological significance.

Receptor Selectivity. Because the investigated uracil derivatives can be envisaged as mimics of fatty acids such as dodecanoic acid, their selectivities versus the $G$ protein-coupled free fatty acid receptors FFAR1 and FFAR4 were subsequently studied (see Tables S1 and S2 for the entire set of compounds). In both, agonist and antagonist assays, none of the compounds activated or inhibited FFAR1 or FFAR4. These results suggest that the developed uracil derivatives can be considered as selective GPR84 agonists versus FFAR1 and FFAR4.

Metabolic Stability. For subsequent in vivo studies, metabolically stable drugs will be required. Therefore, we studied selected potent compounds, namely, 20, 22, 42, and 48, for their metabolic stability in human liver microsomes. Although 6-nonylaminouracil (22) showed a very short half-life of $2 \mathrm{~min}\left(\mathrm{Cl}_{\text {int }} 880 \mu \mathrm{L} / \mathrm{min}\right.$ mg protein $)$, 6-phenethylaminouracil (42) and the two most potent GPR84 agonists of the present series, 6-hexylaminouracil (20) and 6-( $p$-bromophenethylamino) uracil (48), proved to be highly stable (see Figure 7 for 20, 22, and 48 and Figure $S 1$ for $\mathbf{4 2}$ ). Even after an incubation period of $60 \mathrm{~min}$, degradation of 20, 42 , and 48 was negligible. In addition, we investigated the metabolic stability of 2-hexylthiopyrimidine-4,6-diol (5), a GPR84 agonist recently reported by Liu et al. ${ }^{18}$ (Figure 7). Compound $\mathbf{5}$ was metabolized, and after $30 \mathrm{~min}$ of incubation in human microsomes, almost $40 \%$ of the drug had disappeared. In comparison, after the same incubation time, no degradation of 6-aminouracil derivatives 20,42 , and 48 could be observed. This indicates that the potent GPR84 agonists
20 and 48 are metabolically stable and should be useful tools for in vivo studies.

Pharmacophore Modeling. To understand and rationalize important structural features of lipidlike GPR84 agonists, we compared the uracil derivatives 4 (lead structure) and 48 (potency in the low nanomolar range) to those of the known GPR84 agonists 3-hydroxydodecanoic acid (2) and embelin (6), which are $>100$-fold less potent than 48 . Figure $8 \mathrm{~A}$ shows an overall flexible alignment of the selected GPR84 agonists 2, 4, 6, and 48. All four structures overlay very well with several features designated F1-F5 that likely contribute to high GPR84 potency:

(i) A hydrogen bond acceptor (F1) is found in all structures: the carbonyl of the carboxylic acid in 2, the C1-carbonyl group in 6, and the $\mathrm{C} 2$-carbonyl group in the uracil derivatives 4 and 48 . This pharmacophore feature is shown the cyan-colored sphere in Figure 8A,B.

(ii) Three hydrogen bond donors (F2, F3, and F5 shown as the magenta-colored spheres in Figure 8A,B) are found in the most potent agonists, 4 and 48 , namely, $\mathrm{N} 1-\mathrm{H}(\mathrm{F} 2)$, $\mathrm{N}^{6}-\mathrm{H}(\mathrm{F} 3)$, and $\mathrm{N} 3-\mathrm{H}(\mathrm{F} 5)$, whereas agonist 2 has $\mathrm{F} 3$ (3-OH group), but not F2 and F5, and agonist 6 features only F2 (2-OH group).

(iii) A long aliphatic chain or an arylalkyl residue (F4 shown as the green-colored sphere in Figure 8A,B). This feature is found in all agonists. The aromatic ring replacing the terminal part of the aliphatic chain improves hydrophobic interactions and therefore increases potency.

The steric and electronic fit of the four structures is excellent and in agreement with the observed SARs. The additional hydrogen bond donors in the aminouracil derivatives 4 and 48 may be the reason for their improved GPR84 potency as compared to the standard agonists $\mathbf{2}$ and $\mathbf{6}$. The uracil ring, which 
(A)
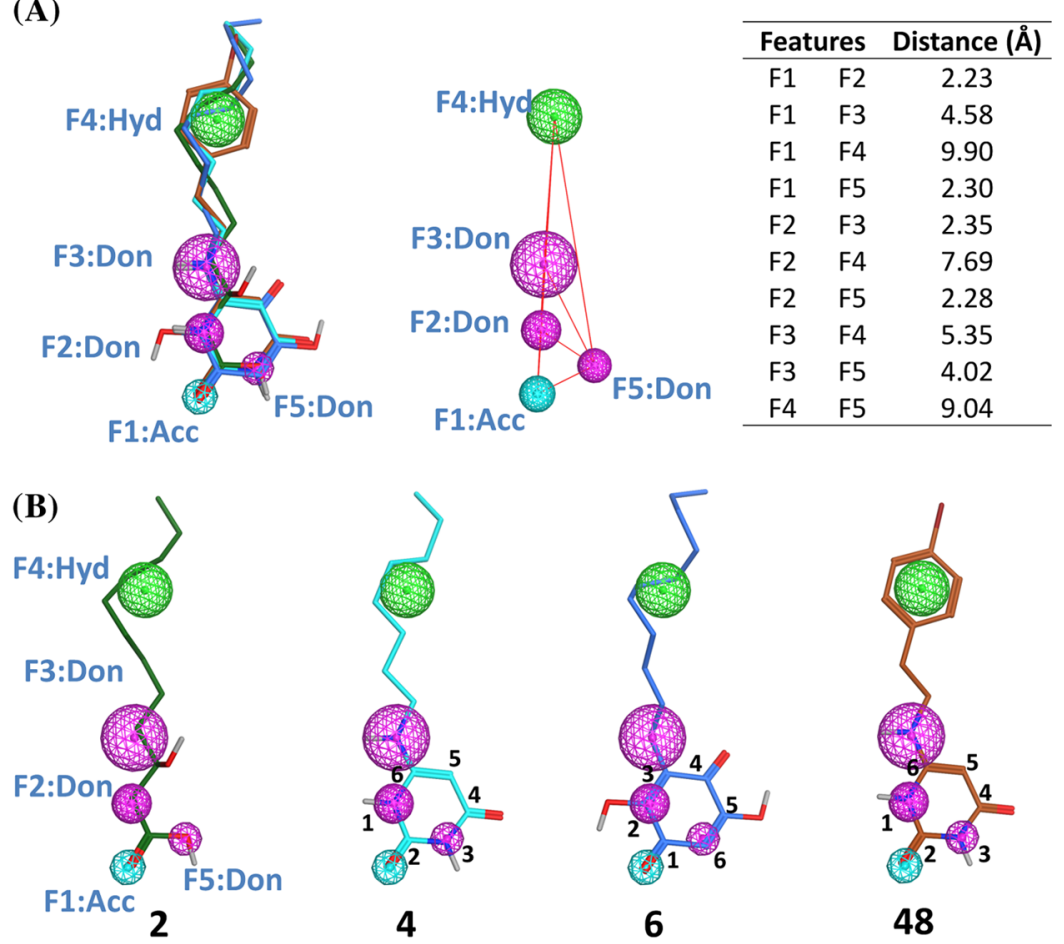

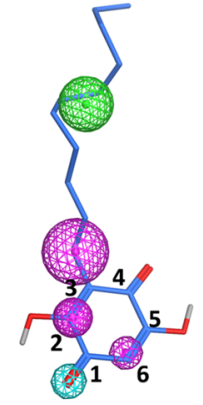

6

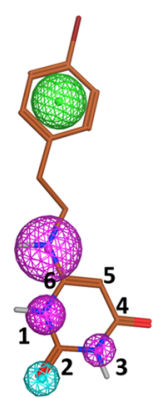

48

(C)
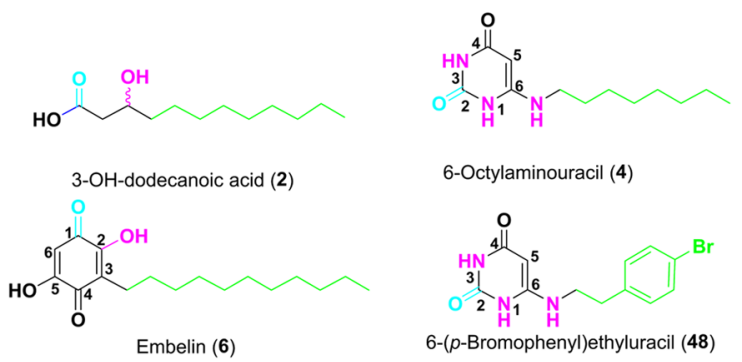

(D)
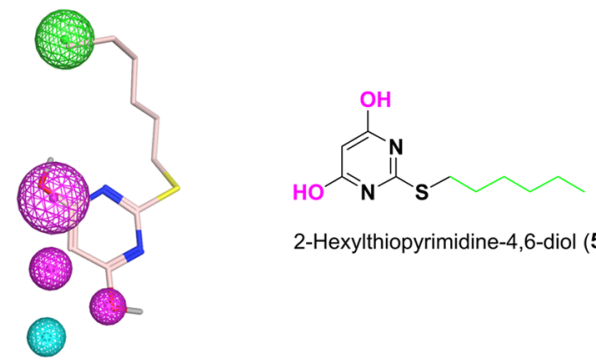

2-Hexylthiopyrimidine-4,6-diol (5)

Figure 8. Overall alignment of the selected GPR84 agonists 2 (green), 4 (cyan), 6 (blue), and 48 (orange). (A) Left: five pharmacophore features were identified (F1: H bond acceptor; F2, F3, and F5: H bond donor; and F4: hydrophobic). Right: the distances between the pharmacophore features are shown as red lines, and the distance ( $\AA$ ) between the features is reported in the table. (B) Each individual GPR84 agonist is shown with the five identified pharmacophore features (F1-F5); oxygen atoms are colored red, nitrogen atoms blue, bromine atoms dark red, and hydrogen atoms silver white; nonpolar hydrogen atoms are omitted. (C) Pharmacophore features are indicated in two-dimensional (2D) representation for 2, 4, 6, and 48 (cyan, hydrogen bond acceptor; magenta, hydrogen bond donor; green, hydrophobic/aromatic domain). (D) Alignment of the previously published agonist 5 with the created pharmacophore model in $2 \mathrm{D}$ representation.

lacks flexibility, keeps the hydrogen bond acceptor and donor features in a fixed position for interaction with the amino acid residues of GPR84.

We subsequently investigated whether the published GPR84 agonist 2-hexylthiopyrimidine-4,6-diol (5) matches the developed pharmacophore model (see Figure $8 \mathrm{D}$ ). In fact, it can be superimposed displaying most of the identified interaction features.

\section{CONCLUSIONS}

In conclusion, a series of 69 6-aralkylamino- and alkylaminosubstituted uracil derivatives was synthesized, of which 66 (13$39,41-65,66-68$, and $70-80$ ) are new compounds that are not previously reported in the literature. Starting from 6octylaminouracil (4) as a lead structure, our goal was to study the SARs of this class of GPR84 agonists, improve their potency determined by $G_{i}$ protein-dependent inhibition of intracellular 
cAMP formation, and obtain metabolically stable compounds suitable for in vivo studies. Many 6-(ar)alkylamino-substituted uracil derivatives showed high GPR84 agonistic activity, whereas substitution at the 5-position reduced or abolished activity. The length of the carbon chain attached at the 6-position of the uracil core determined the potency of compounds. Moreover, the introduction of an aromatic residue into the alkyl chain further improved potency. 6-Hexylamino-2,4 $(1 \mathrm{H}, 3 \mathrm{H})$-pyrimidinedione (20, $\left.\mathrm{EC}_{50} 5.0 \mathrm{nM}\right)$, 6-((p-chlorophenylethyl)amino)-2,4$(1 \mathrm{H}, 3 \mathrm{H})$-pyrimidinedione $\left(47, \mathrm{EC}_{50} 7.1 \mathrm{nM}\right)$, and $6-((p-$ bromophenylethyl)amino)-2,4(1H,3H)-pyrimidinedione (48, $\mathrm{EC}_{50} 2.5 \mathrm{nM}$ ) were found to be the most potent GPR84 agonists of the present series showing high efficacy. Potencies of the selected compounds were further determined in $\beta$-arrestin assays, which indicated that the phenethyl-substituted 6aminouracil derivatives $47-49$ are biased toward $\mathrm{G}_{\mathrm{i}}$-mediated adenylate cyclase inhibition (20- to 79-fold), whereas the alkylsubstituted 20 displayed the same $\mathrm{EC}_{50}$ values in cAMP and $\beta$ arrestin assays and was unbiased. Biased and unbiased agonists may display different pharmacological profiles. For example, it had been suggested that the $\mu$-opioid receptor agonist morphine and related opioids display their severe side effects, such as fatal respiratory depression, by signaling through the $\beta$-arrestin pathway. Therefore, agonists that are $\mathrm{G}_{\mathrm{i}}$-protein-biased and do not induce $\beta$-arrestin recruitment have been developed. ${ }^{34} \mathrm{G}_{\mathrm{i}^{-}}$ protein-biased GPR84 agonists may be devoid of inducing receptor desensitization and thus exhibit longer-lasting effects, or they might trigger different signaling pathways compared to nonbiased agonists.

The new compounds showed high selectivity for GPR84 versus the related GPCRs FFAR1 and FFAR4 that display an overlapping ligand preference regarding fatty acids. The new GPR84 agonists, which exhibit excellent metabolic stability, will be useful tool compounds for elucidating the physiologic roles and therapeutic potential of GPR84

\section{EXPERIMENTAL SECTION}

General Methods. All commercially available reagents were used as purchased (Acros, Alfa Aesar, Sigma-Aldrich, ABCR or TCI). Solvents were used without additional purification or drying except for dichloromethane, which was distilled over calcium hydride. The reactions were monitored by thin-layer chromatography (TLC) using aluminum sheets with silica gel 60 $\mathrm{F}_{254}$ (Merck). Column chromatography was performed with $0.060-0.200 \mathrm{~mm}$ silica gel with pore diameter of ca. $6 \mathrm{~nm}$. All synthesized compounds were finally dried in vacuum at $8-12 \mathrm{~Pa}$ (0.08-0.12 mbar) using a sliding vane rotary vacuum pump (Vacuubrand $\mathrm{GmbH}) .{ }^{1} \mathrm{H}$ and ${ }^{13} \mathrm{C}$ NMR data were collected on a Bruker Avance $500 \mathrm{MHz}$ NMR spectrometer at 500 and 126 $\mathrm{MHz}$, respectively. If indicated, NMR data were collected on a Bruker Ascend $600 \mathrm{MHz} N M R$ spectrometer at $600 \mathrm{MHz}\left({ }^{1} \mathrm{H}\right)$ and $151 \mathrm{MHz}\left({ }^{13} \mathrm{C}\right)$. DMSO- $d_{6}$ was employed as a solvent at 303 $\mathrm{K}$, unless otherwise noted. Chemical shifts are reported in parts per million ( $\mathrm{ppm}$ ) relative to the deuterated solvent, that is, DMSO, $\delta{ }^{1} \mathrm{H}$ : $2.49 \mathrm{ppm} ;{ }^{13} \mathrm{C}: 39.7 \mathrm{ppm}$. Coupling constants J are given in hertz, and spin multiplicities are given as s (singlet), $\mathrm{d}$ (doublet), $\mathrm{t}$ (triplet), q (quartet), sext. (sextet), m (multiplet), and br (broad). Melting points were determined on a Büchi 530 melting point apparatus and are uncorrected. The purities of isolated products were determined by ESI-mass spectra obtained on an liquid chromatography-mass spectrometry (LC-MS) instrument (Applied Biosystems API 2000 LCMS/MS, HPLC Agilent 1100) using the following procedure: the compounds were dissolved at a concentration of $1.0 \mathrm{mg} / \mathrm{mL}$ in acetonitrile containing $2 \mathrm{mM}$ ammonium acetate. Then, $10 \mu \mathrm{L}$ of the sample was injected into an HPLC column (Macherey-Nagel Nucleodur $3 \mu \mathrm{C} 18,50 \times 2.00 \mathrm{~mm}^{2}$ ). Elution was performed with a gradient of water/acetonitrile (containing $2 \mathrm{mM}$ ammonium acetate) from 90:10 to $0: 100$ for $20 \mathrm{~min}$ at a flow rate of $300 \mu \mathrm{L} / \mathrm{min}$, starting the gradient after $10 \mathrm{~min}$. UV absorption was detected from 200 to $950 \mathrm{~nm}$ using a diode array detector. Purity of all compounds was determined at $254 \mathrm{~nm}$. The purity of the compounds was generally $\geq 95 \%$.

Compounds $13^{8}$ and $69^{31,32}$ have previously been described. Compound $\mathbf{5}$ was synthesized according to a reported synthetic procedure. ${ }^{18}$ The synthesis and structural characterization of the new compounds are described below. Data for compounds 14$18,24-27,29,30,34-36,39-41,47,59,66,72,75,76$, and 79 are reported in Supporting Information.

General Synthetic Procedure for the Preparation of 4 and 13-71. A suspension of 6-chlorouracil $(10 \mathrm{mmol})$ and the appropriate amine ( $50 \mathrm{mmol}, 5$ equiv) in 1-butanol $(20 \mathrm{~mL})$ was refluxed at $125^{\circ} \mathrm{C}$ for $12 \mathrm{~h}$. The reaction was cooled to rt, and half of the solvent was removed by evaporation under reduced pressure. The precipitated solid was filtered off, washed with 1butanol $(\sim 20 \mathrm{~mL})$, followed by diethyl ether $(\sim 20 \mathrm{~mL})$, and dried under vacuum.

General Synthetic Procedure for the Preparation of 72-75. To a solution of the appropriate 6-alkylaminouracil derivative $(10 \mathrm{mmol})$ in dry pyridine $(2 \mathrm{~mL})$ was added $\mathrm{N}$-bromosuccinimide (NBS, $10 \mathrm{mmol}$ ) under an Ar atmosphere. The solution was heated to $80{ }^{\circ} \mathrm{C}$ for $2 \mathrm{~h}$ and cooled to rt. The precipitated solid was filtered off, washed with diethyl ether $(\sim 25 \mathrm{~mL})$, and subjected into column chromatography to afford the desire product.

General Synthetic Procedure for the Preparation of 76-80. To a suspension of 5-alkylaminouracil (5 mmol) in water/acetic acid $(6.0: 6.0 \mathrm{~mL})$ heated at $60-70{ }^{\circ} \mathrm{C}$ was added a solution of sodium nitrite $(10 \mathrm{mmol}, 2.0$ equiv) in water $(2 \mathrm{~mL})$. The resulting solution was stirred at the same temperature for $1 \mathrm{~h}$ and then cooled to $4{ }^{\circ} \mathrm{C}$. The resulting suspension was filtered off and washed with cold water $(2 \times 50 \mathrm{~mL})$ to afford the product.

6-Pentylamino-2,4(1H,3H)-pyrimidinedione (19). Compound 19 was synthesized using 6-chlorouracil $(11,10 \mathrm{mmol})$ and 1 -aminopentane ( $50 \mathrm{mmol}, 5$ equiv) and was isolated as an off-white solid (99\% yield). ${ }^{1} \mathrm{H}$ NMR (600 MHz, DMSO- $\left.d_{6}\right) \delta$ (ppm) $6.63(\mathrm{~s}, 1 \mathrm{H}, 1-\mathrm{NH}), 4.34(\mathrm{~s}, 1 \mathrm{H}, 5-\mathrm{H}), 2.95(\mathrm{td}, J=7.1,4.9$ $\mathrm{Hz}, 2 \mathrm{H}, \mathrm{NHCH}_{2}$ ), 1.47 (p, J=7.2 Hz, 2H, $\mathrm{CH}_{2}$ ), 1.37 (p, J= 7.3 $\left.\mathrm{Hz}, 2 \mathrm{H}, \mathrm{CH}_{2}\right), 1.27-1.24\left(\mathrm{~m}, 4 \mathrm{H}, 2 \times-\mathrm{CH}_{2}\right), 0.86(\mathrm{t}, J=6.9,4.1$ $\left.\mathrm{Hz}, 3 \mathrm{H},-\mathrm{CH}_{3}\right) ;{ }^{13} \mathrm{C}$ NMR $(151 \mathrm{MHz}$, DMSO-d $) \delta 164.54$ (4C), 155.67 (2-C), 152.44 (6-C), 72.38 (5-C), 31.53 (NH-C), $28.66\left(\mathrm{CH}_{2}\right), 22.08\left(\mathrm{CH}_{2}\right), 21.92\left(\mathrm{CH}_{2}\right), 14.06\left(\mathrm{CH}_{3}\right)$; LC-MS positive mode: $197[\mathrm{M}+\mathrm{H}]^{1+}$; purity by HPLC-UV $(254 \mathrm{~nm})$ ESI-MS: $98 \%$. mp: $259-261{ }^{\circ} \mathrm{C}$.

6-Hexylamino-2,4(1H,3H)-pyrimidinedione (20). Compound 20 was synthesized using 6-chlorouracil $(11,10 \mathrm{mmol})$ and 1-aminohexane ( $50 \mathrm{mmol}, 5$ equiv) and was isolated as a yellow solid (89\% yield). ${ }^{1} \mathrm{H}$ NMR (500 MHz, DMSO- $\left.d_{6}\right) \delta$ (ppm) 10.09 (s, 1H, 1-NH), $9.77(\mathrm{~s}, 1 \mathrm{H}, 3-\mathrm{NH}), 6.03$ (t, $J=5.7$ $\mathrm{Hz}, 1 \mathrm{H}, 6-\mathrm{NH}$ ), 4.38 (d, $J=1.5 \mathrm{~Hz}, 1 \mathrm{H}, 5-\mathrm{H}), 2.97$ (dd, $J=7.1$, $\left.5.5 \mathrm{~Hz}, 2 \mathrm{H}, \mathrm{NH}-\mathrm{CH}_{2}\right), 1.46\left(\mathrm{~m}, 2 \mathrm{H}, \mathrm{CH}_{2}\right), 1.39-1.11(\mathrm{~m}, 6 \mathrm{H}, 3$ $\left.\times \mathrm{CH}_{2}\right), 0.99-0.61\left(\mathrm{~m}, 3 \mathrm{H}, \mathrm{CH}_{3}\right) ;{ }^{13} \mathrm{C}$ NMR $(126 \mathrm{MHz}$, DMSO-d $d_{6} \delta$ (ppm) 164.27 (4-C), 154.12 (2-C), 150.87 (6-C), $72.54(5-\mathrm{C}), 30.96\left(\mathrm{NH}-\mathrm{CH}_{2}\right), 28.20\left(\mathrm{CH}_{2}\right), 26.00\left(2 \times \mathrm{CH}_{2}\right)$, $22.12\left(\mathrm{CH}_{2}\right), 13.97\left(\mathrm{CH}_{3}\right)$; LC-MS $(\mathrm{m} / z)$ : positive mode 291 
$[\mathrm{M}+\mathrm{H}]^{1+}$; purity by HPLC-UV (254 nm)-ESI-MS: $98 \%$. mp: $263-265^{\circ} \mathrm{C}$.

6-Heptylamino-2,4(1H,3H)-pyrimidinedione (21). Compound 21 was synthesized using 6-chlorouracil $(11,10 \mathrm{mmol})$ and 1 -aminoheptan ( $50 \mathrm{mmol}, 5$ equiv) and was isolated as a yellow solid (94\% yield). ${ }^{1} \mathrm{H}$ NMR (600 MHz, DMSO- $\left.d_{6}\right) \delta$ (ppm) $6.50(\mathrm{~s}, 1 \mathrm{H}, 6-\mathrm{NH}), 4.35(\mathrm{~s}, 1 \mathrm{H}, 5-\mathrm{H}), 2.95(\mathrm{q}, J=6.6 \mathrm{~Hz}$, $\left.2 \mathrm{H}, \mathrm{NHCH}_{2}\right), 1.46\left(\mathrm{~m}, 4 \mathrm{H}, \mathrm{CH}_{2}\right), 1.33-1.06\left(\mathrm{~m}, 6 \mathrm{H}, 3 \times \mathrm{CH}_{2}\right)$, $0.85\left(\mathrm{t}, J=6.9 \mathrm{~Hz}, 3 \mathrm{H}, \mathrm{CH}_{3}\right) ;{ }^{13} \mathrm{C}$ NMR $\left(151 \mathrm{MHz}\right.$, DMSO- $\left.d_{6}\right) \delta$ 164.38 (4-C), 154.59 (2-C), 151.12 (6-C), 72.36 (5-C), 31.34 $\left(\mathrm{NH}-\mathrm{CH}_{2}\right), 31.26\left(\mathrm{CH}_{2}\right), 28.71\left(\mathrm{CH}_{2}\right), 28.45\left(2 \times \mathrm{CH}_{2}\right), 22.14$ $\left(\mathrm{CH}_{2}\right), 14.07\left(\mathrm{CH}_{3}\right)$; LC-MS $(\mathrm{m} / z)$ : positive mode $225[\mathrm{M}+$ $\mathrm{H}]^{1+}$; purity by HPLC-UV (254 nm)-ESI-MS: $98 \%$. mp: $196-$ $198{ }^{\circ} \mathrm{C}$.

6-Nonylamino-2,4(1H,3H)-pyrimidinedione (22). Compound 22 was synthesized using 6-chlorouracil $(11,10 \mathrm{mmol})$ and 1 -aminononane ( $50 \mathrm{mmol}, 5$ equiv) and was isolated as an off-white solid (99\% yield). ${ }^{1} \mathrm{H}$ NMR (600 MHz, DMSO- $\left.d_{6}\right) \delta$ (ppm) 6.57 (s, 1H, 6-NH), $4.34(\mathrm{~s}, 1 \mathrm{H}, 5-\mathrm{H}), 2.95(\mathrm{q}, J=6.5 \mathrm{~Hz}$, $\left.2 \mathrm{H}, \mathrm{NHCH}_{2}\right), 1.46\left(\mathrm{p}, J=7.0 \mathrm{~Hz}, 2 \mathrm{H}, \mathrm{CH}_{2}\right), 1.36(\mathrm{p}, J=7.0 \mathrm{~Hz}$, $\left.2 \mathrm{H}, \mathrm{CH}_{2}\right), 1.30-1.07\left(\mathrm{~m}, 10 \mathrm{H}, 5 \times \mathrm{CH}_{2}\right), 0.85(\mathrm{t}, J=6.8 \mathrm{~Hz}, 3 \mathrm{H}$, $\left.\mathrm{CH}_{3}\right) ;{ }^{13} \mathrm{C}$ NMR (151 MHz, DMSO-d $\left.d_{6}\right) \delta 164.50$ (4-C), 155.53 (2-C), 152.29 (6-C), 72.38 (5-C), $31.90\left(\mathrm{NH}-\mathrm{CH}_{2}\right), 31.39$, 29.11, 29.06, 29.02, 28.81, 28.26, 26.40, $22.21\left(7 \times \mathrm{CH}_{2}\right), 14.06$ $\left(\mathrm{CH}_{3}\right) ; \mathrm{LC}-\mathrm{MS}(\mathrm{m} / \mathrm{z})$ : positive mode $253[\mathrm{M}+\mathrm{H}]^{1+}$; purity by HPLC-UV (254 nm)-ESI-MS: 98\%. mp: $161-263{ }^{\circ} \mathrm{C}$.

6-Decylamino-2,4(1H,3H)-pyrimidinedione (23). Compound 23 was synthesized using 6-chlorouracil $(11,10 \mathrm{mmol})$ and 1 -aminodecane ( $50 \mathrm{mmol}, 5$ equiv) and was isolated as an off-white solid (92\% yield). ${ }^{1} \mathrm{H}$ NMR (500 MHz, DMSO- $\left.d_{6}\right) \delta$ (ppm) $10.09(\mathrm{~s}, 1 \mathrm{H}, 1-\mathrm{NH}), 9.77(\mathrm{~s}, 1 \mathrm{H}, 3-\mathrm{H}), 6.02(\mathrm{t}, J=5.0 \mathrm{~Hz}$, $1 \mathrm{H}, 6-\mathrm{NH}), 4.37$ (d, $J=1.5 \mathrm{~Hz}, 1 \mathrm{H}, 5-\mathrm{H}), 3.10-2.71(\mathrm{~m}, 2 \mathrm{H}$, $\left.\mathrm{NHCH}_{2}\right), 1.46\left(\mathrm{p}, J=6.9 \mathrm{~Hz}, 2 \mathrm{H}, \mathrm{CH}_{2}\right), 1.25(\mathrm{~d}, J=12.8 \mathrm{~Hz}$, $\left.14 \mathrm{H}, 7 \times \mathrm{CH}_{2}\right), 0.95-0.50\left(\mathrm{~m}, 3 \mathrm{H}, \mathrm{CH}_{3}\right) ;{ }^{13} \mathrm{C} \mathrm{NMR}(126 \mathrm{MHz}$, DMSO-d $d_{6} \delta 164.29$ (4-C), 154.14 (2-C), 150.90 (2-C), 72.57 (5-C), $31.40\left(\mathrm{NHCH}_{2}\right), 29.08\left(\mathrm{CH}_{2}\right), 29.03\left(\mathrm{CH}_{2}\right), 28.79$, 28.76, 28.24, 26.35, $22.19\left(5 \times \mathrm{CH}_{2}\right), 14.05\left(\mathrm{CH}_{3}\right) ; \mathrm{LC}-\mathrm{MS}(\mathrm{m} /$ $z)$ : positive mode $267[\mathrm{M}+\mathrm{H}]^{1+}$; purity by HPLC-UV $(254$ nm)-ESI-MS: $98 \%$. mp: $270-272{ }^{\circ} \mathrm{C}$.

6-(7-Hydroxyheptylamino)-2,4(1H,3H)-pyrimidinedione (28). Compound 28 was synthesized using 6-chlorouracil (11, 10 $\mathrm{mmol})$ and 1-amino-7-hydroxyheptane ( $50 \mathrm{mmol}, 5$ equiv) and was isolated as a white solid (89\% yield). ${ }^{1} \mathrm{H}$ NMR (600 MHz, DMSO- $\left.d_{6}\right) \delta(\mathrm{ppm}) 10.10(\mathrm{~s}, 1 \mathrm{H}, 1-\mathrm{NH}), 9.78(\mathrm{~s}, 1 \mathrm{H}, 1-\mathrm{NH})$, $6.06(\mathrm{~s}, 1 \mathrm{H}, 6-\mathrm{NH}), 4.38(\mathrm{~d}, J=1.4 \mathrm{~Hz}, 1 \mathrm{H}, 5-\mathrm{H}), 4.29(\mathrm{t}, J=5.2$ $\mathrm{Hz}, 1 \mathrm{H}, \mathrm{OH}), 3.36\left(\mathrm{dd}, J=6.5,4.9 \mathrm{~Hz}, 2 \mathrm{H}, \mathrm{OCH}_{2}\right), 2.97(\mathrm{dd}, J=$ 7.0, $\left.5.4 \mathrm{~Hz}, 2 \mathrm{H}, \mathrm{NH}-\mathrm{CH}_{2}\right), 1.39\left(\mathrm{~m}, 2 \mathrm{H}, \mathrm{CH}_{2}\right), 1.26(\mathrm{~d}, J=6.0$ $\left.\mathrm{Hz}, 6 \mathrm{H}, 3 \times \mathrm{CH}_{2}\right) ;{ }^{13} \mathrm{C}$ NMR $\left(151 \mathrm{MHz}, \mathrm{DMSO}-d_{6}\right) \delta 164.34$ (4-C), 154.19 (2-C), 150.95 (6-C), 72.59 (5-C), 60.86 (O$\left.\mathrm{CH}_{2}\right), 32.67\left(\mathrm{NHCH}_{2}\right), 29.03\left(\mathrm{CH}_{2}\right), 28.86\left(\mathrm{CH}_{2}\right), 28.28$ $\left(\mathrm{CH}_{2}\right), 26.38\left(\mathrm{CH}_{2}\right), 25.59\left(2 \times \mathrm{CH}_{2}\right) ; \mathrm{LC}-\mathrm{MS}(\mathrm{m} / z)$ : positive mode $257[\mathrm{M}+\mathrm{H}]^{1+}$; purity by HPLC-UV (254 nm)-ESI-MS: 99.7\%. mp: $238-240{ }^{\circ} \mathrm{C}$.

6-Heptylamino-3-methyl-2,4(1H,3H)-pyrimidinedione (31). Compound 31 was synthesized using 6-chloro-3methyluracil (12a, $10 \mathrm{mmol}$ ) and 1-aminoheptane $(50 \mathrm{mmol}$, 5 equiv) and was isolated as a white solid ( $86 \%$ yield). ${ }^{1} \mathrm{H}$ NMR $\left(600 \mathrm{MHz}, \mathrm{DMSO}-d_{6}\right) \delta(\mathrm{ppm}) 10.10(\mathrm{~s}, 1 \mathrm{H}, 1-\mathrm{NH}), 6.15$ (s, $1 \mathrm{H}, 6-\mathrm{NH}), 4.54(\mathrm{~s}, 1 \mathrm{H}, 5-\mathrm{H}), 3.01\left(\mathrm{~s}, 3 \mathrm{H}, 3-\mathrm{CH}_{3}\right), 2.98(\mathrm{td}, J=$ 7.0, $\left.5.5 \mathrm{~Hz}, 2 \mathrm{H}, \mathrm{NH}-\mathrm{CH}_{2}\right), 1.46\left(\mathrm{p}, J=6.8 \mathrm{~Hz}, 2 \mathrm{H}, \mathrm{CH}_{2}\right), 1.35-$ $1.16\left(\mathrm{~m}, 10 \mathrm{H}, 5 \times \mathrm{CH}_{2}\right), 0.85\left(\mathrm{t}, J=6.8 \mathrm{~Hz}, 3 \mathrm{H}, \mathrm{CH}_{3}\right) ;{ }^{13} \mathrm{C} \mathrm{NMR}$ $\left(151 \mathrm{MHz}, \mathrm{DMSO}-d_{6}\right) \delta 163.29$ (4-C), $157.66(2-\mathrm{C}), 153.22$ (6C), $72.52(5-\mathrm{C}), 41.36\left(\mathrm{~N}-\mathrm{CH}_{3}\right), 31.36\left(\mathrm{NHCH}_{2}\right), 28.77$
$\left(\mathrm{CH}_{2}\right), 28.31\left(\mathrm{CH}_{2}\right), 26.38\left(\mathrm{CH}_{2}\right), 26.38\left(\mathrm{CH}_{2}\right), 22.22\left(\mathrm{CH}_{2}\right)$, $14.09\left(\mathrm{CH}_{3}\right)$; LC-MS $(\mathrm{m} / \mathrm{z})$ : positive mode $254[\mathrm{M}+\mathrm{H}]^{1+}$; purity by HPLC-UV (254 nm)-ESI-MS: 98.5\%. mp: 207-209 ${ }^{\circ} \mathrm{C}$.

6-Nonylamino-3-methyl-2,4(1H,3H)-pyrimidinedione (32). Compound 32 was synthesized using 6-chloro-3-methyluracil (12a, $10 \mathrm{mmol}$ ) and 1 -aminononane $(50 \mathrm{mmol}, 5$ equiv) and was isolated as a yellow solid (97\% yield). ${ }^{1} \mathrm{H}$ NMR $(500 \mathrm{MHz}$, DMSO- $\left.d_{6}\right) \delta(\mathrm{ppm}) 6.50(\mathrm{~m}, 1 \mathrm{H}, 6-\mathrm{NH}), 4.51(\mathrm{~s}, 1 \mathrm{H}, 5-\mathrm{H}), 3.01$ $\left(\mathrm{s}, 3 \mathrm{H}, \mathrm{CH}_{3}\right), 2.97\left(\mathrm{q}, J=6.6 \mathrm{~Hz}, 2 \mathrm{H}, \mathrm{NHCH}_{2}\right), 1.53(\mathrm{~m}, 4 \mathrm{H}, 2 \times$ $\left.\mathrm{CH}_{2}\right), 1.46\left(\mathrm{~m}, 4 \mathrm{H}, 2 \times \mathrm{CH}_{2}\right), 0.91-0.85\left(\mathrm{~m}, 9 \mathrm{H}, 3 \times \mathrm{CH}_{2}\right.$ and $\left.\mathrm{CH}_{3}\right) ;{ }^{13} \mathrm{C}$ NMR (126 MHz, DMSO- $\left.d_{6}\right) \delta 163.28$ (4-C), 152.76 $(2 \times \mathrm{C}), 150.99(6-\mathrm{C}), 72.29(5-\mathrm{C}), 31.38\left(\mathrm{NHCH}_{2}\right), 29.04(\mathrm{~N}-$ $\left.\mathrm{CH}_{3}\right), 28.90\left(\mathrm{CH}_{2}\right), 28.78\left(2 \times \mathrm{CH}_{2}\right), 28.65\left(\mathrm{CH}_{2}\right), 28.26$ $\left(\mathrm{CH}_{2}\right), 27.08\left(\mathrm{CH}_{2}\right), 26.36\left(\mathrm{CH}_{2}\right), 26.00\left(\mathrm{CH}_{2}\right), 22.20\left(\mathrm{CH}_{2}\right)$, $14.05\left(\mathrm{CH}_{3}\right)$; LC-MS $(\mathrm{m} / z)$ : positive mode $267[\mathrm{M}+\mathrm{H}]^{1+}$; purity by HPLC-UV (254 nm)-ESI-MS: 96.9\%. mp: 143-145 ${ }^{\circ} \mathrm{C}$.

6-Decylamino-3-methyl-2,4(1H,3H)-pyrimidinedione (33). Compound 33 was synthesized using 6-chloro-3-methyluracil (12a, $10 \mathrm{mmol}$ ) and 1 -aminodecane ( $50 \mathrm{mmol}, 5$ equiv) and was isolated as a white solid (98\% yield). ${ }^{1} \mathrm{H}$ NMR (500 MHz, DMSO- $\left.d_{6}\right) \delta(\mathrm{ppm}) 10.19(\mathrm{~s}, 1 \mathrm{H}, 3-\mathrm{NH}), 6.01(\mathrm{~s}, 1 \mathrm{H}, 6-\mathrm{NH})$, $4.54(\mathrm{~s}, 1 \mathrm{H}, 5-\mathrm{H}), 3.01\left(\mathrm{~s}, 3 \mathrm{H}, \mathrm{N}-\mathrm{CH}_{3}\right), 3.00-2.88(\mathrm{~m}, 2 \mathrm{H}$, $\left.\mathrm{NH}-\mathrm{CH}_{2}\right), 1.46\left(\mathrm{p}, J=7.1 \mathrm{~Hz}, 2 \mathrm{H}, \mathrm{CH}_{2}\right), 1.33-1.11(\mathrm{~m}, 14 \mathrm{H}, 7$ $\left.\times \mathrm{CH}_{2}\right), 0.93-0.71\left(\mathrm{~m}, 3 \mathrm{H}, \mathrm{CH}_{3}\right) ;{ }^{13} \mathrm{C} \mathrm{NMR}(126 \mathrm{MHz}$, DMSO-d ${ }_{6}$ ) 163.23 (4-C), 152.56 (2-C), 151.08 (6-C), 72.49 (5C), $31.38\left(\mathrm{~N}-\mathrm{CH}_{3}\right), 29.06\left(\mathrm{~N}-\mathrm{CH}_{2}\right), 28.77\left(\mathrm{CH}_{2}\right), 28.25$ $\left(\mathrm{CH}_{2}\right), 26.31\left(\mathrm{CH}_{2}\right), 26.00\left(\mathrm{CH}_{2}\right), 22.18\left(\mathrm{CH}_{2}\right), 14.04\left(\mathrm{CH}_{3}\right)$; LC-MS $(m / z)$ : positive mode $281[\mathrm{M}+\mathrm{H}]^{1+}$; purity by HPLCUV (254 nm)-ESI-MS: $95.3 \%$. mp: $210-212{ }^{\circ} \mathrm{C}$.

6-(N-Methylhexylamino)-2,4(1H,3H)-pyrimidinedione (37). Compound 37 was synthesized using 6-chlorouracil (11, 10 $\mathrm{mmol}$ ) and 1-methylaminohexane (50 mmol, 5 equiv) and was isolated as a yellow solid (92\% yield). ${ }^{1} \mathrm{H}$ NMR (500 MHz, DMSO- $\left.d_{6}\right) \delta(\mathrm{ppm}) 10.16(\mathrm{~s}, 1 \mathrm{H}, 1-\mathrm{NH}), 4.39(\mathrm{~s}, 1 \mathrm{H}, 5-\mathrm{H}), 3.29$ $\left(\mathrm{s}, 3 \mathrm{H}, \mathrm{N}-\mathrm{CH}_{3}\right), 2.85\left(\mathrm{~s}, 3 \mathrm{H}, \mathrm{N}-\mathrm{CH}_{2}\right), 1.55$ (p, J = 8.0, 7.6 Hz, $\left.2 \mathrm{H}, \mathrm{CH}_{2}\right), 1.44\left(\mathrm{p}, J=7.3 \mathrm{~Hz}, 2 \mathrm{H}, \mathrm{CH}_{2}\right), 1.26-121(\mathrm{~m}, 6 \mathrm{H}, 3 \times$ $\left.\mathrm{CH}_{2}\right), 0.86\left(\mathrm{td}, J=6.8,3.9 \mathrm{~Hz}, 3 \mathrm{H}, \mathrm{CH}_{3}\right) ;{ }^{13} \mathrm{C}$ NMR $(126 \mathrm{MHz}$, DMSO- $\left.d_{6}\right) \delta 163.90$ (4-C), 154.43 (2-C), 151.60 (6-C), 74.65 $(5-\mathrm{C}), 37.10\left(\mathrm{~N}-\mathrm{CH}_{3}\right), 32.79\left(\mathrm{~N}-\mathrm{CH}_{2}\right), 26.65\left(\mathrm{CH}_{2}\right), 25.76(2$ $\left.\times \mathrm{CH}_{2}\right), 22.18\left(2 \times \mathrm{CH}_{2}\right), 13.96\left(\mathrm{CH}_{3}\right) ;$ LC-MS $(\mathrm{m} / z)$ : positive mode $226[\mathrm{M}+\mathrm{H}]^{1+}$; purity by HPLC-UV $(254 \mathrm{~nm})$ ESI-MS: >99\%. mp: $162-164^{\circ} \mathrm{C}$.

6-(N-Methyloctylamino)-2,4(1H,3H)-pyrimidinedione (38). Compound 38 was synthesized using 6-chlorouracil (11, 10 $\mathrm{mmol}$ ) and $\mathrm{N}$-methyloctylamine (50 mmol, 5 equiv) and was isolated as pale yellow solid (93\% yield). ${ }^{1} \mathrm{H}$ NMR (500 MHz, DMSO- $\left.d_{6}\right) \delta(\mathrm{ppm}) 8.86(\mathrm{~s}, 1 \mathrm{H}, 3-\mathrm{NH}), 4.41(\mathrm{~s}, 1 \mathrm{H}, 5-\mathrm{H})$, 2.86-2.65 (m, 2H, $\left.\mathrm{NHCH}_{2}\right), 1.79-1.43\left(\mathrm{~m}, 2 \mathrm{H}, \mathrm{CH}_{2}\right), 1.35-$ $1.11\left(\mathrm{~m}, 10 \mathrm{H}, 5 \times \mathrm{CH}_{2}\right), 0.95-0.68\left(\mathrm{~m}, 3 \mathrm{H}, \mathrm{CH}_{3}\right) ;{ }^{13} \mathrm{C} \mathrm{NMR}$ $\left(126 \mathrm{MHz}, \mathrm{DMSO}-d_{6}\right) \delta 164.00$ (4-C), 155.13 (2-C), 151.63 (6C), $73.65(5-\mathrm{C}), 51.32\left(\mathrm{~N}-\mathrm{CH}_{3}\right), 31.87\left(\mathrm{~N}-\mathrm{CH}_{2}\right), 26.61$ $\left(\mathrm{CH}_{2}\right), 25.66\left(\mathrm{CH}_{2}\right), 24.32\left(\mathrm{CH}_{2}\right), 22.28\left(\mathrm{CH}_{2}\right), 21.99\left(\mathrm{CH}_{2}\right)$, $13.91\left(\mathrm{CH}_{3}\right)$; LC-MS $(\mathrm{m} / z)$ : positive mode $253[\mathrm{M}+\mathrm{H}]^{1+}$; purity by HPLC-UV (254 nm)-ESI-MS: >99\%. mp: 182-184 ${ }^{\circ} \mathrm{C}$.

6-(2-Phenylethylamino)-2,4(1H,3H)-pyrimidinedione (42). Compound 42 was synthesized using 6-chlorouracil (11, 10 $\mathrm{mmol}$ ) and 2-phenethylamine (50 mmol, 5 equiv) and was isolated as a white solid (95\% yield). ${ }^{1} \mathrm{H}$ NMR (500 MHz, DMSO- $\left.d_{6}\right) \delta(\mathrm{ppm}) 10.03(\mathrm{~s}, 1 \mathrm{H}, 1-\mathrm{NH}), 9.15(\mathrm{~s}, 1 \mathrm{H}, 6-\mathrm{NH})$, 7.44-7.28 (m, $2 \mathrm{H}, 2 \times \mathrm{Ar}-\mathrm{H}), 7.28-7.17(\mathrm{~m}, 3 \mathrm{H}, 3 \times \mathrm{Ar}-\mathrm{H})$, 
$4.46(\mathrm{~s}, 1 \mathrm{H}, 5-\mathrm{H}), 3.26-3.10\left(\mathrm{~m}, 2 \mathrm{H}, \mathrm{NH}-\mathrm{CH}_{2}\right), 2.79(\mathrm{t}, J=7.2$ $\left.\mathrm{Hz}, 2 \mathrm{H}, \mathrm{Ar}-\mathrm{CH}_{2}\right) ;{ }^{13} \mathrm{C}$ NMR (126 MHz, DMSO-d $) \delta 164.39$ (4-C), 154.20 (2-C), 151.06 (6-C), 138.87 ( $\mathrm{Ar}-\mathrm{C}), 128.87$ ( $\mathrm{Ar}-$ C), $128.78(\mathrm{Ar}-\mathrm{C}), 128.63(\mathrm{Ar}-\mathrm{C}), 128.54(\mathrm{Ar}-\mathrm{C}), 126.45$ (Ar-C), 72.84 (5-C), $42.74\left(\mathrm{NHCH}_{2}\right), 34.26\left(\mathrm{Ar}-\mathrm{CH}_{2}\right)$; LCMS $(m / z)$ : positive mode $231[\mathrm{M}+\mathrm{H}]^{1+}$; purity by HPLC-UV (254 nm)-ESI-MS: >98\%. mp: $292-294{ }^{\circ} \mathrm{C}$.

6-(3-Phenylpropylamino)-2,4(1H,3H)-pyrimidinedione (43). Compound 43 was synthesized using 6-chlorouracil (11, 10 mmol) and 3-phenylpropylamine (50 mmol, 5 equiv) and was isolated as a white solid (91\% yield). ${ }^{1} \mathrm{H}$ NMR $(500 \mathrm{MHz}$, DMSO- $\left.d_{6}\right) \delta$ (ppm) 7.30-7.24 (m, 2H, $\left.2 \times \mathrm{Ar}-\mathrm{H}\right), 7.21-7.13$ (m, 3H, $3 \times \mathrm{Ar}-\mathrm{H}), 6.69$ (s, 1H, 6-NH), 4.33 (s, 1H, 5-H), 2.98 (td, $\left.J=7.1,4.9 \mathrm{~Hz}, 2 \mathrm{H}, \mathrm{NHCH}_{2}\right), 2.65-2.58\left(\mathrm{~m}, 2 \mathrm{H}, \mathrm{Ar}-\mathrm{CH}_{2}\right)$, 1.91-1.45 (m, 2H, $\left.\mathrm{CH}_{2}\right) ;{ }^{13} \mathrm{C}$ NMR (126 MHz, DMSO-d $\left.d_{6}\right) \delta$ 164.57 (4-C), 155.62 (2-C), 152.40 (6-C), 141.57 ( $\mathrm{Ar}-\mathrm{C})$, 128.48 ( $\mathrm{Ar}-\mathrm{C}), 128.45(\mathrm{Ar}-\mathrm{C}), 128.40(\mathrm{Ar}-\mathrm{C}), 125.97$ ( $\mathrm{Ar}-$ C), 125.87 ( $\mathrm{Ar}-\mathrm{C}), 72.51(5-\mathrm{C}), 33.03\left(\mathrm{NHCH}_{2}\right), 32.52(\mathrm{Ar}-$ $\left.\mathrm{CH}_{2}\right), 30.14\left(\mathrm{CH}_{2}\right)$. LC-MS $(\mathrm{m} / z)$ : positive mode $245[\mathrm{M}+$ $\mathrm{H}]^{1+}$; purity by HPLC UV (254 nm)-ESI-MS: >99\%. mp: $283-$ $285^{\circ} \mathrm{C}$.

6-(4-Phenylbutylamino)-2,4(1H,3H)-pyrimidinedione (44). Compound 44 was synthesized using 6-chlorouracil (11, 10 mmol) and phenylbutylamine (50 mmol, 5 equiv) and was isolated as a pale yellow solid (97\% yield). ${ }^{1} \mathrm{H}$ NMR (500 MHz, DMSO- $\left.d_{6}\right) \delta(\mathrm{ppm}) 7.26(\mathrm{t}, J=7.5 \mathrm{~Hz}, 2 \mathrm{H}, 2 \times \mathrm{Ar}-\mathrm{H}), 7.21-$ $7.11(\mathrm{~m}, 3 \mathrm{H}, 3 \times \mathrm{Ar}-\mathrm{H}), 6.60(\mathrm{~s}, 1 \mathrm{H}, 6-\mathrm{NH}), 4.35(\mathrm{~s}, 1 \mathrm{H}, 5-\mathrm{H})$, $2.99\left(\mathrm{q}, J=6.6 \mathrm{~Hz}, 2 \mathrm{H}, \mathrm{NHCH}_{2}\right), 2.60-2.55\left(\mathrm{~m}, 2 \mathrm{H}, \mathrm{Ar}-\mathrm{CH}_{2}\right)$, $1.58\left(\mathrm{~m}, 2 \mathrm{H}, \mathrm{CH}_{2}\right), 1.52-1.44\left(\mathrm{~m}, 2 \mathrm{H}, \mathrm{CH}_{2}\right) ;{ }^{13} \mathrm{C} \mathrm{NMR}(126$ MHz, DMSO- $\left.d_{6}\right) \delta 164.52$ (4-C), 155.57 (2-C), 152.36 (6-C), $142.14(\mathrm{Ar}-\mathrm{C}), 128.41(\mathrm{Ar}-\mathrm{C}), 128.37(\mathrm{Ar}-\mathrm{C}), 128.34(\mathrm{Ar}-$ C), $125.81(\mathrm{Ar}-\mathrm{C}), 125.75(\mathrm{Ar}-\mathrm{C}), 72.46$ (5-C), $34.84(\mathrm{NH}-$ $\left.\mathrm{CH}_{2}\right), 31.54\left(\mathrm{Ar}-\mathrm{CH}_{2}\right), 28.38\left(\mathrm{CH}_{2} \mathrm{CH}_{2}\right) ; \mathrm{LC}-\mathrm{MS}(\mathrm{m} / z)$ : positive mode $259[\mathrm{M}+\mathrm{H}]^{1+}$; purity by HPLC-UV $(254 \mathrm{~nm})$ ESI-MS: $>98 \%$. mp: $165-167^{\circ} \mathrm{C}$.

6-(p-Methylphenylethylamino)-2,4(1H,3H)-pyrimidinedione (45). Compound 45 was synthesized using 6-chlorouracil $(11,10 \mathrm{mmol})$ and 1-( $p$-methylphenyl)ethylamine $(50 \mathrm{mmol}, 5$ equiv) and was isolated as a white solid (96\% yield). ${ }^{1} \mathrm{H}$ NMR $\left(500 \mathrm{MHz}, \mathrm{DMSO}-d_{6}\right) \delta(\mathrm{ppm}) 10.12(\mathrm{~s}, 1 \mathrm{H}, 1-\mathrm{NH}), 9.35$ (s, $1 \mathrm{H}, 3-\mathrm{NH}), 7.29-6.76(\mathrm{~m}, 4 \mathrm{H}, 4 \times \mathrm{Ar}-\mathrm{H}), 6.09(\mathrm{~s}, 1 \mathrm{H}, 6-\mathrm{NH})$, $4.46(\mathrm{~s}, 1 \mathrm{H}, 5-\mathrm{H}), 3.25-3.05\left(\mathrm{~m}, 2 \mathrm{H}, \mathrm{NHCH}_{2}\right), 2.74(\mathrm{t}, J=7.2$ $\left.\mathrm{Hz}, 2 \mathrm{H}, \mathrm{Ar}-\mathrm{CH}_{2}\right), 2.26$ (s, 3H, $\left.\mathrm{Ar}-\mathrm{CH}_{3}\right) ;{ }^{13} \mathrm{C} \mathrm{NMR}(126 \mathrm{MHz}$, DMSO-d 6 ) $\delta 164.35$ (4-C), 154.02 (2-C), 150.90 (6-C), 135.69 $(\mathrm{Ar}-\mathrm{C}), 135.42(\mathrm{Ar}-\mathrm{C}), 129.12(\mathrm{Ar}-\mathrm{C}), 128.74(\mathrm{Ar}-\mathrm{C}), 72.83$ (5-C), $42.80\left(\mathrm{NHCH}_{2}\right), 33.80\left(\mathrm{Ar}-\mathrm{CH}_{2}\right), 20.75\left(\mathrm{Ar}-\mathrm{CH}_{3}\right)$; LC-MS $(m / z)$ : positive mode $245[\mathrm{M}+\mathrm{H}]^{1+}$; purity by HPLC UV (254 nm)-ESI-MS: $95.7 \%$. mp: $>300{ }^{\circ} \mathrm{C}$.

6-(p-Fluorophenylethylamino)-2,4(1H,3H)-pyrimidinedione (46). Compound 46 was synthesized using 6-chlorouracil (11, $10 \mathrm{mmol})$ and 1-(p-fluorophenyl)ethylamine $(50 \mathrm{mmol}, 5$ equiv) and was isolated as a pale light yellow solid (79\% yield). ${ }^{1} \mathrm{H} \mathrm{NMR}\left(500 \mathrm{MHz}, \mathrm{DMSO}-d_{6}\right) \delta$ (ppm) 7.25-7.23 (m, 2H, $2 \times$ Ar-H), 7.18-6.98 (m, 2H, $2 \times \mathrm{Ar}-\mathrm{H}), 4.45$ (s, 1H, 5-H), 3.23 (dd, $\left.J=7.2,5.4 \mathrm{~Hz}, 2 \mathrm{H}, \mathrm{NHCH}_{2}\right), 2.79(\mathrm{td}, J=7.1,4.6 \mathrm{~Hz}, 2 \mathrm{H}$, $\left.\mathrm{Ar}-\mathrm{CH}_{2}\right) ;{ }^{13} \mathrm{C}$ NMR (126 MHz, DMSO-d 6 ) $\delta 164.42$ (4-C), 154.55 (2-C), 151.43 (6-C), $135.05(\mathrm{Ar}-\mathrm{C}), 130.72(\mathrm{Ar}-\mathrm{C})$, $130.66(\mathrm{Ar}-\mathrm{C}), 130.48(\mathrm{Ar}-\mathrm{C}), 115.26(\mathrm{Ar}-\mathrm{C}), 114.96(\mathrm{Ar}-$ C), 72.83 (5-C), $42.76\left(\mathrm{NHCH}_{2}\right), 33.41\left(\mathrm{Ar}-\mathrm{CH}_{2}\right)$. LC-MS $(\mathrm{m} / z)$ : positive mode $249[\mathrm{M}+\mathrm{H}]^{1+}$; purity by HPLC-UV $(254$ nm)-ESI-MS: $95.5 \%$. mp: $280-282{ }^{\circ} \mathrm{C}$.

6-(p-Bromophenylethylamino)-2,4(1H,3H)-pyrimidinedione (48). Compound 48 was synthesized using 6-chlorouracil
(11, $10 \mathrm{mmol})$ and 1-( $p$-bromophenyl)ethylamine $(50 \mathrm{mmol}, 5$ equiv) and was isolated as a light brown solid (87\% yield). ${ }^{1} \mathrm{H}$ NMR $\left(500 \mathrm{MHz}, \mathrm{DMSO}-d_{6}\right) \delta$ (ppm) $9.41(\mathrm{~s}, 1 \mathrm{H}, 1-\mathrm{NH})$, 7.51-7.47 (m, 2H, $2 \times \mathrm{Ar}-\mathrm{H}), 7.24-7.19(\mathrm{~m}, 2 \mathrm{H}, 2 \times \mathrm{Ar}-\mathrm{H})$, $6.03(\mathrm{~s}, 1 \mathrm{H}, 3-\mathrm{NH}), 4.47$ (s, 1H, 5-H), 3.25 (dd, $J=7.2,5.6 \mathrm{~Hz}$, $\left.2 \mathrm{H}, \mathrm{NHCH}_{2}\right), 2.77\left(\mathrm{t}, J=7.1 \mathrm{~Hz}, 2 \mathrm{H}, \mathrm{Ar}-\mathrm{CH}_{2}\right) ;{ }^{13} \mathrm{C} \mathrm{NMR}(126$ $\left.\mathrm{MHz}, \mathrm{DMSO}-d_{6}\right) \delta 164.34$ (4-C), 154.09 (2-C), 151.00 (6-C), 138.35 (Ar-C), 131.35 ( $\mathrm{Ar}-\mathrm{C}), 131.30(\mathrm{Ar}-\mathrm{C}), 131.21$ ( $\mathrm{Ar}-$ C), 119.57 ( $\mathrm{Ar}-\mathrm{C}), 72.91(5-\mathrm{C}), 42.39\left(\mathrm{NHCH}_{2}\right), 33.57(\mathrm{Ar}-$ $\left.\mathrm{CH}_{2}\right)$; LC-MS $(\mathrm{m} / z)$ : positive mode $291[\mathrm{M}+\mathrm{H}]^{1+}$; purity by HPLC-UV (254 nm)-ESI-MS: >97\%. mp: $>300{ }^{\circ} \mathrm{C}$.

6-(p-Ethylphenylethylamino)-2,4(1H,3H)-pyrimidinedione (49). Compound 49 was synthesized using 6-chlorouracil (11, 10 $\mathrm{mmol})$ and 1-( $p$-ethylphenyl)ethylamine (50 mmol, 5 equiv) and was isolated as a pale brown solid ( $74 \%$ yield). ${ }^{1} \mathrm{H}$ NMR (600 MHz, DMSO- $\left.d_{6}\right) \delta(\mathrm{ppm}) 7.21-6.83(\mathrm{~m}, 4 \mathrm{H}, 4 \times \mathrm{Ar}-\mathrm{H}), 4.44$ $(\mathrm{s}, 1 \mathrm{H}, 5-\mathrm{H}), 3.22$ (td, $\left.J=7.1,5.0 \mathrm{~Hz}, 2 \mathrm{H}, \mathrm{NHCH}_{2}\right), 2.77$ (dt, $J=$ 23.0, 7.1 Hz, 2H, $\left.\mathrm{Ar}-\mathrm{CH}_{2}\right), 2.55\left(\mathrm{~m}, 2 \mathrm{H}, \mathrm{Ar}-\mathrm{CH}_{2}\right), 1.15(\mathrm{t}, J=$ 7.6, $\left.\mathrm{Hz}, 3 \mathrm{H}, \mathrm{CH}_{3}\right) ;{ }^{13} \mathrm{C}$ NMR $(151 \mathrm{MHz}$, DMSO-d 6 ) $\delta 164.48$ (4-C), 154.87 (2-C), 151.76 (6-C), 141.80 (Ar-C), 136.09 (ArC), $128.78(\mathrm{Ar}-\mathrm{C}), 128.70(\mathrm{Ar}-\mathrm{C}), 127.92(\mathrm{Ar}-\mathrm{C}), 127.82$ $(\mathrm{Ar}-\mathrm{C}), 72.73(5-\mathrm{C}), 43.02\left(\mathrm{NH}-\mathrm{CH}_{2}\right), 42.91\left(\mathrm{Ar}-\mathrm{CH}_{2}\right)$, $33.87\left(\mathrm{Ar}-\mathrm{CH}_{2}\right), 15.8\left(\mathrm{CH}_{3}\right)$; LC-MS $(\mathrm{m} / z)$ : positive mode $259[\mathrm{M}+\mathrm{H}]^{1+}$; purity by HPLC-UV (254 nm)-ESI-MS: $95.5 \%$. mp: $270-272{ }^{\circ} \mathrm{C}$.

6-(p-Methoxyphenylethylamino)-2,4(1H,3H)-pyrimidinedione (50). Compound 50 was synthesized using 6-chlorouracil $(11,10 \mathrm{mmol})$ and 1-( $p$-methoxyphenyl)ethylamine $(50 \mathrm{mmol}$, 5 equiv) and was isolated as a brown solid (82\% yield). ${ }^{1} \mathrm{H}$ NMR $\left(500 \mathrm{MHz}, \mathrm{DMSO}-d_{6}\right) \delta(\mathrm{ppm}) 12.37(\mathrm{~s}, 1 \mathrm{H}, 1-\mathrm{NH}), 6.60$ (dd, $J$ $=9.4,2.0 \mathrm{~Hz}, 2 \mathrm{H}, 2 \times \mathrm{Ar}-\mathrm{H}), 6.44(\mathrm{dd}, J=12.4,2.1 \mathrm{~Hz}, 2 \mathrm{H}, 2 \times$ $\mathrm{Ar}-\mathrm{H}), 4.96(\mathrm{~s}, 1 \mathrm{H}, 5-\mathrm{H}), 3.88\left(\mathrm{~s}, 3 \mathrm{H}, \mathrm{O}-\mathrm{CH}_{3}\right), 2.98(\mathrm{t}, J=6.5$ $\left.\mathrm{Hz}, 2 \mathrm{H}, \mathrm{NHCH}_{2}\right), 2.53\left(\mathrm{t}, J=6.8 \mathrm{~Hz}, 2 \mathrm{H}, \mathrm{Ar}-\mathrm{CH}_{2}\right) ;{ }^{13} \mathrm{C} \mathrm{NMR}$ $\left(126 \mathrm{MHz}, \mathrm{DMSO}-d_{6}\right) \delta 164.04$ (4-C), 162.98 (2-C), 159.21 (6C), $137.20(\mathrm{Ar}-\mathrm{C}), 126.66(\mathrm{Ar}-\mathrm{C}), 122.53(\mathrm{Ar}-\mathrm{C}), 114.73$ (Ar-C), 71.60 (5-C), $45.33\left(\mathrm{OCH}_{3}\right), 35.90\left(\mathrm{NHCH}_{2}\right), 21.20$ $\left(\mathrm{Ar}-\mathrm{CH}_{2}\right)$; LC-MS $(\mathrm{m} / z)$ : positive mode $261[\mathrm{M}+\mathrm{H}]^{1+}$; purity by HPLC-UV (254 nm)-ESI-MS: 95.0\%. mp: 282-284 ${ }^{\circ} \mathrm{C}$.

6-(p-tert-Butylphenylethylamino)-2,4(1H,3H)-pyrimidinedione (51). Compound 51 was synthesized using 6-chlorouracil $(11,10 \mathrm{mmol})$ and 1 -(p-tert-butylphenyl)ethylamine $(50 \mathrm{mmol}$, 5 equiv) and was isolated as a white solid (76\% yield). ${ }^{1} \mathrm{H}$ NMR $\left(600 \mathrm{MHz}, \mathrm{DMSO}-d_{6}\right) \delta(\mathrm{ppm}) 10.13(\mathrm{~s}, 1 \mathrm{H}, 1-\mathrm{NH}), 9.87$ (s, $1 \mathrm{H}, 3-\mathrm{NH}), 7.31(\mathrm{~d}, J=1.9 \mathrm{~Hz}, 2 \mathrm{H}, 2 \times \mathrm{Ar}-\mathrm{H}), 7.19-7.13(\mathrm{~m}$, $2 \mathrm{H}, 2 \times \mathrm{Ar}-\mathrm{H}), 6.01(\mathrm{~s}, 1 \mathrm{H}, 6-\mathrm{NH}), 4.47(\mathrm{~s}, 1 \mathrm{H}, 5-\mathrm{H}), 3.24(\mathrm{td}, J$ $\left.=7.1,5.4 \mathrm{~Hz}, 2 \mathrm{H}, \mathrm{NHCH}_{2}\right), 2.75\left(\mathrm{t}, J=7.1 \mathrm{~Hz}, 2 \mathrm{H}, \mathrm{Ar}-\mathrm{CH}_{2}\right)$, $1.25\left(\mathrm{~s}, 9 \mathrm{H}, \mathrm{C}\left(\mathrm{CH}_{3}\right)_{3}\right) ;{ }^{13} \mathrm{C} \mathrm{NMR}\left(151 \mathrm{MHz}, \mathrm{DMSO}-d_{6}\right) \delta$ 164.37 (4-C), 154.03 (2-C), 150.92 (6-C), 135.74 ( $\mathrm{Ar}-\mathrm{C})$, $128.54(\mathrm{Ar}-\mathrm{C}), 125.30(\mathrm{Ar}-\mathrm{C}), 72.86(5-\mathrm{C}), 42.72\left(\mathrm{NHCH}_{2}\right)$, $34.25\left(\mathrm{Ar}-\mathrm{CH}_{2}\right), 31.34\left(\mathrm{C}\left(\mathrm{CH}_{3}\right)_{3}\right) ; \mathrm{LC}-\mathrm{MS}(\mathrm{m} / z)$ : positive mode $287[\mathrm{M}+\mathrm{H}]^{1+}$; purity by HPLC-UV $(254 \mathrm{~nm})$-ESI-MS: $>98.0 \%$. mp: $>300{ }^{\circ} \mathrm{C}$.

6-(m-Methylphenylethylamino)-2,4(1H,3H)-pyrimidinedione (52). Compound 52 was synthesized using 6-chlorouracil $(11,10 \mathrm{mmol})$ and $1-(m$-methylphenyl)ethylamine $(50 \mathrm{mmol}, 5$ equiv) and was isolated as a white solid ( $83 \%$ yield). ${ }^{1} \mathrm{H}$ NMR $\left(600 \mathrm{MHz}, \mathrm{DMSO}-d_{6}\right) \delta(\mathrm{ppm}) 7.61-7.57(\mathrm{~m}, 2 \mathrm{H}, 2 \times \mathrm{Ar}-\mathrm{H})$, 7.40-7.30 (m, 1H, Ar-H), 7.18 (s, 1H, Ar-H), 6.39 (s, 1H, 6$\mathrm{NH}$ ), 4.46 (s, 1H, 5-H), 3.22 (q, $\left.J=6.8 \mathrm{~Hz}, 2 \mathrm{H}, \mathrm{NHCH}_{2}\right), 2.75$ $\left(\mathrm{t}, J=7.2 \mathrm{~Hz}, 2 \mathrm{H}, \mathrm{Ar}-\mathrm{CH}_{2}\right), 2.27\left(\mathrm{~s}, 3 \mathrm{H}, \mathrm{Ar}-\mathrm{CH}_{3}\right) ;{ }^{13} \mathrm{C} \mathrm{NMR}$ $\left(151 \mathrm{MHz}, \mathrm{DMSO}-d_{6}\right) \delta 166.12$ (4-C), 154.97 (2-C), 153.32 (6C), $141.94(\mathrm{Ar}-\mathrm{C}), 127.81(\mathrm{Ar}-\mathrm{C}), 122.37(\mathrm{Ar}-\mathrm{C}), 121.34$ 
(Ar-C), 125.81 (Ar-C), 125.75 (Ar-C), 72.46 (5-C), 34.84 $\left(\mathrm{NHCH}_{2}\right), 31.54\left(\mathrm{Ar}-\mathrm{CH}_{2}\right), 28.38\left(\mathrm{Ar}-\mathrm{CH}_{3}\right)$. LC-MS $(\mathrm{m} / z)$ : positive mode $291[\mathrm{M}+\mathrm{H}]^{1+}$; purity by HPLC-UV $(254 \mathrm{~nm})$ ESI-MS: $95.7 \%$. mp: $229-231^{\circ} \mathrm{C}$.

6-(m-Fluorophenylethylamino)-2,4(1H,3H)-pyrimidinedione (53). Compound 53 was synthesized using 6-chlorouracil (11, $10 \mathrm{mmol})$ and 1-( $\mathrm{m}$-fluorophenyl)ethylamine $(50 \mathrm{mmol}, 5$ equiv) and was isolated as a yellow solid (91\% yield). ${ }^{1} \mathrm{H}$ NMR $\left(500 \mathrm{MHz}, \mathrm{DMSO}-d_{6}\right) \delta(\mathrm{ppm}) 10.14(\mathrm{~s}, 1 \mathrm{H}, 3-\mathrm{NH}), 7.37-7.23$ $(\mathrm{m}, 2 \mathrm{H}, 2 \times \mathrm{Ar}-\mathrm{H}), 7.21-7.10(\mathrm{~m}, 2 \mathrm{H}, 2 \times \mathrm{Ar}-\mathrm{H}), 4.48(\mathrm{~s}, 1 \mathrm{H}$, $5-\mathrm{H}$ ), 3.26 (dd, $J=7.4,6.0 \mathrm{~Hz}, 2 \mathrm{H}, \mathrm{NHCH}_{2}$ ), 2.83 (t, $J=7.2 \mathrm{~Hz}$, $\left.2 \mathrm{H}, \mathrm{Ar}-\mathrm{CH}_{2}\right) ;{ }^{13} \mathrm{C}$ NMR $\left(126 \mathrm{MHz}\right.$, DMSO- $\left.d_{6}\right) \delta 164.37$ (4-C), 159.91 (2-C), 154.06 (6-C), 131.42 ( $\mathrm{Ar}-\mathrm{C}), 128.71(\mathrm{Ar}-\mathrm{C})$, $128.64(\mathrm{Ar}-\mathrm{C}), 125.40(\mathrm{Ar}-\mathrm{C}), 115.40(\mathrm{Ar}-\mathrm{C}), 115.22(\mathrm{Ar}-$ C), 72.84 (5-C), $41.52\left(\mathrm{NHCH}_{2}\right), 27.67\left(\mathrm{Ar}-\mathrm{CH}_{2}\right)$; LC-MS $(\mathrm{m} / z)$ : positive mode $249[\mathrm{M}+\mathrm{H}]^{1+}$; purity by HPLC-UV $(254$ nm)-ESI-MS: $>98.0 \%$. mp: $>300{ }^{\circ} \mathrm{C}$.

6-(m-Chlorophenylethylamino)-2,4(1H,3H)-pyrimidinedione (54). Compound 54 was synthesized using 6-chlorouracil $(11,10 \mathrm{mmol})$ and 1-( $m$-chlorophenyl)ethylamine (50 mmol, 5 equiv) and was isolated as a white solid (94\% yield). ${ }^{1} \mathrm{H}$ NMR $\left(600 \mathrm{MHz}, \mathrm{DMSO}-d_{6}\right) \delta(\mathrm{ppm}) 10.13(\mathrm{~s}, 1 \mathrm{H}, 3-\mathrm{NH}), 9.38-7.30$ $(\mathrm{m}, 2 \mathrm{H}, 2 \times \mathrm{Ar}-\mathrm{H}), 7.27$ (dd, $J=8.0,2.2 \mathrm{~Hz}, 1 \mathrm{H}, \mathrm{Ar}-\mathrm{H}), 7.22(\mathrm{~s}$, $1 \mathrm{H}, \mathrm{Ar}-\mathrm{H}), 4.49(\mathrm{~s}, 1 \mathrm{H}), 3.27\left(\mathrm{dd}, J=7.2,5.6 \mathrm{~Hz}, 2 \mathrm{H}, \mathrm{NHCH}_{2}\right)$, $2.80\left(\mathrm{t}, J=7.1 \mathrm{~Hz}, 2 \mathrm{H}, \mathrm{Ar}-\mathrm{CH}_{2}\right) ;{ }^{13} \mathrm{C}$ NMR $(151 \mathrm{MHz}, \mathrm{DMSO}-$ $\left.d_{6}\right) \delta 164.36$ (4-C), 154.02 (2-C), 150.94 (6-C), 141.53 (Ar-C), $133.15(\mathrm{Ar}-\mathrm{C}), 130.33(\mathrm{Ar}-\mathrm{C}), 128.82(\mathrm{Ar}-\mathrm{C}), 127.71(\mathrm{Ar}-$ C), 126.47, $72.98(\mathrm{Ar}-\mathrm{C}), 42.34\left(\mathrm{NHCH}_{2}\right), 33.84\left(\mathrm{Ar}-\mathrm{CH}_{2}\right)$; LC-MS $(m / z)$ : positive mode $265[\mathrm{M}+\mathrm{H}]^{1+}$; purity by HPLCUV (254 nm)-ESI-MS: >98.0\%. mp: $283-285^{\circ} \mathrm{C}$.

6-(m-Bromophenylethylamino)-2,4(1H,3H)-pyrimidinedione (55). Compound 55 was synthesized using 6-chlorouracil (11, $10 \mathrm{mmol})$ and 1-( $m$-bromophenyl)ethylamine ( $50 \mathrm{mmol}, 5$ equiv) and was isolated as a white solid (93\% yield). ${ }^{1} \mathrm{H}$ NMR $\left(600 \mathrm{MHz}, \mathrm{DMSO}-d_{6}\right) \delta(\mathrm{ppm}) 7.56-7.47(\mathrm{~m}, 1 \mathrm{H}, \mathrm{Ar}-\mathrm{H})$, 7.47-7.36 (m, 3H, $3 \times \mathrm{Ar}-\mathrm{H}), 6.21(\mathrm{~s}, 1 \mathrm{H}, 3-\mathrm{NH}), 4.49(\mathrm{~s}, 1 \mathrm{H}$, $5-\mathrm{H}), 3.26\left(\mathrm{~d}, J=6.8 \mathrm{~Hz}, 2 \mathrm{H}, \mathrm{NH}-\mathrm{CH}_{2}\right), 2.79(\mathrm{t}, J=7.1 \mathrm{~Hz}, 2 \mathrm{H}$, $\left.\mathrm{Ar}-\mathrm{CH}_{2}\right) ;{ }^{13} \mathrm{C}$ NMR (151 MHz, DMSO-d 6 ) $\delta 164.37$ (4-C), 154.06 (2-C), 150.94 (6-C), 141.82 (Ar-C), 131.67 ( $\mathrm{Ar}-\mathrm{C})$, 130.63 ( $\mathrm{Ar}-\mathrm{C}), 129.74(\mathrm{Ar}-\mathrm{C}), 129.36(\mathrm{Ar}-\mathrm{C}), 128.08$ ( $\mathrm{Ar}-$ C), 72.94 (5-C), $42.36\left(\mathrm{NHCH}_{2}\right), 33.82\left(\mathrm{Ar}-\mathrm{CH}_{2}\right)$; LC-MS $(\mathrm{m} / z)$ : positive mode $309[\mathrm{M}+\mathrm{H}]^{1+}$; purity by HPLC-UV $(254$ nm)-ESI-MS: $>98.0 \%$. mp: $264-266{ }^{\circ} \mathrm{C}$.

6-(o-Methylphenylethylamino)-2,4(1H,3H)-pyrimidinedione (56). Compound 56 was synthesized using 6-chlorouracil (11, $10 \mathrm{mmol})$ and 1-(o-methylphenyl)ethylamine (50 mmol, 5 equiv) and was isolated as a white solid (89\% yield). ${ }^{1} \mathrm{H}$ NMR $\left(600 \mathrm{MHz}, \mathrm{DMSO}-d_{6}\right) \delta(\mathrm{ppm}) 10.12(\mathrm{~s}, 1 \mathrm{H}, 1-\mathrm{NH}), 7.27-7.07$ $(\mathrm{m}, 4 \mathrm{H}, 4 \times \mathrm{Ar}-\mathrm{H}), 4.47(\mathrm{~s}, 1 \mathrm{H}, 5-\mathrm{H}), 3.26-3.12(\mathrm{~m}, 2 \mathrm{H}$, $\left.\mathrm{NHCH}_{2}\right), 2.79\left(\mathrm{t}, J=7.4 \mathrm{~Hz}, 2 \mathrm{H}, \mathrm{Ar}-\mathrm{CH}_{2}\right), 2.28(\mathrm{~s}, 3 \mathrm{H}, \mathrm{Ar}-$ $\left.\mathrm{CH}_{3}\right) ;{ }^{13} \mathrm{C}$ NMR (151 MHz, DMSO-d 6 ) $\delta 165.60$ (4-C), 164.39 (2-C), 154.14 (6-C), 136.13 ( $\mathrm{Ar}-\mathrm{C}), 130.39$ (Ar-C), 129.29 (Ar-C), 126.95 ( $\mathrm{Ar}-\mathrm{C}), 126.27$ (Ar-C), 72.75 (5-C), 41.72 $\left(\mathrm{NHCH}_{2}\right), 31.68\left(\mathrm{Ar}-\mathrm{CH}_{2}\right), 19.10\left(\mathrm{Ar}-\mathrm{CH}_{3}\right) ; \mathrm{LC}-\mathrm{MS}(\mathrm{m} / z)$ : positive mode $245[\mathrm{M}+\mathrm{H}]^{1+}$; purity by HPLC-UV $(254 \mathrm{~nm})$ ESI-MS: $>96.0 \%$. mp: $298-300{ }^{\circ} \mathrm{C}$.

6-(o-Fluorophenylethylamino)-2,4(1H,3H)-pyrimidinedione (57). Compound 57 was synthesized using 6-chlorouracil (11, $10 \mathrm{mmol})$ and 1-(o-methylphenyl)ethylamine ( $50 \mathrm{mmol}, 5$ equiv) and was isolated as a white solid (78\% yield). ${ }^{1} \mathrm{H}$ NMR $\left(600 \mathrm{MHz}, \mathrm{DMSO}-d_{6}\right) \delta(\mathrm{ppm}) 10.14(\mathrm{~s}, 1 \mathrm{H}, 1-\mathrm{NH}), 7.49-7.21$ (m, 1H, Ar-H), 7.20-6.82 (m, 3H, Ar-H), 6.02 (s, 1H, 3-NH), 4.59 (s, 1H, 5-H), 3.27-3.26 (m, 2H, $\left.\mathrm{NHCH}_{2}\right), 2.81(\mathrm{t}, J=7.1$
$\left.\mathrm{Hz}, 2 \mathrm{H}, \mathrm{Ar}-\mathrm{CH}_{2}\right) ;{ }^{13} \mathrm{C}$ NMR (151 MHz, DMSO-d 6 ) $\delta 164.36$ (4-C), 154.02 (2-C), 150.93 (6-C), 141.83 (Ar-C), 130.33 ( $\mathrm{Ar}-$ C), $125.08(\mathrm{Ar}-\mathrm{C}), 115.73(\mathrm{Ar}-\mathrm{C}), 115.60(\mathrm{Ar}-\mathrm{C}), 113.17$ (Ar-C), 72.95 (5-C), $42.33\left(\mathrm{NHCH}_{2}\right), 33.92\left(\mathrm{Ar}-\mathrm{CH}_{2}\right)$; LCMS $(m / z)$ : positive mode $249[\mathrm{M}+\mathrm{H}]^{1+}$; purity by HPLC-UV (254 nm)-ESI-MS: $95.4 \%$. mp: $285-287{ }^{\circ} \mathrm{C}$.

6-(o-Chlorophenylethylamino)-2,4(1H,3H)-pyrimidinedione (58). Compound 58 was synthesized using 6-chlorouracil (11, $10 \mathrm{mmol})$ and 1-(o-chlorophenyl)ethylamine $(50 \mathrm{mmol}, 5$ equiv) and was isolated as a light yellow solid ( $88 \%$ yield). ${ }^{1} \mathrm{H}$ NMR $\left(500 \mathrm{MHz}, \mathrm{DMSO}-d_{6}\right) \delta$ (ppm) $10.13(\mathrm{~s}, 1 \mathrm{H}, 1-\mathrm{NH})$, 7.48-7.22 (m, 4H, $4 \times \mathrm{Ar}-\mathrm{H}), 6.12(\mathrm{~s}, 1 \mathrm{H}, 6-\mathrm{NH}), 4.50(\mathrm{~s}, 1 \mathrm{H}$, 5-H), 3.28-3.22 (m, 2H, $\left.\mathrm{NHCH}_{2}\right), 2.92(\mathrm{dd}, J=7.9,6.6 \mathrm{~Hz}, 2 \mathrm{H}$, $\left.\mathrm{Ar}-\mathrm{CH}_{2}\right) ;{ }^{13} \mathrm{C}$ NMR (126 MHz, DMSO-d $) \delta 164.34$ (4-C), 154.05 (2-C), 150.93 (6-C), 136.21 ( $\mathrm{Ar}-\mathrm{C}), 133.27$ ( $\mathrm{Ar}-\mathrm{C})$, 131.35 (Ar-C), 129.40 ( $\mathrm{Ar}-\mathrm{C}), 128.54(\mathrm{Ar}-\mathrm{C}), 127.49$ ( $\mathrm{Ar}-$ C), 72.85 (5-C), $41.12\left(\mathrm{NHCH}_{2}\right), 32.10\left(\mathrm{Ar}-\mathrm{CH}_{2}\right)$; LC-MS $(\mathrm{m} / z)$ : positive mode $265[\mathrm{M}+\mathrm{H}]^{1+}$; purity by HPLC-UV $(254$ nm)-ESI-MS: $96.7 \%$. mp: $289-291{ }^{\circ} \mathrm{C}$.

6-(m,p-Dimethoxyphenethylamino)-2,4(1H,3H)-pyrimidinedione (60). Compound $\mathbf{6 0}$ was synthesized using 6chlorouracil (11, $10 \mathrm{mmol})$ and 1-(m,p-dimethoxyphenyl)ethylamine ( $50 \mathrm{mmol}, 5$ equiv) and was isolated as a white solid (92\% yield). ${ }^{1} \mathrm{H}$ NMR (500 MHz, DMSO- $\left.d_{6}\right) \delta(\mathrm{ppm})$ 6.95-6.80 (m, 2H, $2 \times \mathrm{Ar}-\mathrm{H}), 6.74(\mathrm{dd}, J=8.2,2.0 \mathrm{~Hz}, 1 \mathrm{H}, \mathrm{Ar}-$ $\mathrm{H}), 6.09(\mathrm{~s}, 1 \mathrm{H}, 6-\mathrm{NH}), 4.48(\mathrm{~s}, 1 \mathrm{H}, 5-\mathrm{H}), 3.74\left(\mathrm{~s}, 3 \mathrm{H}, \mathrm{OCH}_{3}\right)$, $3.71\left(\mathrm{~s}, 3 \mathrm{H}, \mathrm{OCH}_{3}\right), 3.24\left(\mathrm{td}, J=7.2,5.6 \mathrm{~Hz}, 2 \mathrm{H}, \mathrm{NHCH}_{2}\right), 2.72$ $\left(\mathrm{t}, J=7.1 \mathrm{~Hz}, 2 \mathrm{H}, \mathrm{Ar}-\mathrm{CH}_{2}\right) ;{ }^{13} \mathrm{C}$ NMR $\left(126 \mathrm{MHz}\right.$, DMSO- $\left.d_{6}\right) \delta$ 164.42 (4-C), 154.55 (2-C), 151.43 (6-C), 135.05 (Ar-C), $130.72(\mathrm{Ar}-\mathrm{C}), 130.66(\mathrm{Ar}-\mathrm{C}), 130.55(\mathrm{Ar}-\mathrm{C}), 115.26(\mathrm{Ar}-$ $\mathrm{C}), 114.96(\mathrm{Ar}-\mathrm{C}), 72.83(5-\mathrm{C}), 43.04\left(\mathrm{OCH}_{3}\right), 42.76\left(\mathrm{OCH}_{3}\right)$, $37.71\left(\mathrm{NHCH}_{2}\right)$, $33.41\left(\mathrm{Ar}-\mathrm{CH}_{2}\right)$; LC-MS $(\mathrm{m} / z)$ : positive mode $291[\mathrm{M}+\mathrm{H}]^{1+}$; purity by HPLC-UV (254 nm)-ESI-MS: >99\%. mp: $265-267{ }^{\circ} \mathrm{C}$.

6-(o,p-Dichlorophenethylamino)-2,4(1H,3H)-pyrimidinedione (61). Compound 61 was synthesized using 6-chlorouracil $(11,10 \mathrm{mmol})$ and 1-(o,p-dichlorophenyl)ethylamine (50 mmol, 5 equiv) and was isolated as a white solid (96\% yield). ${ }^{1} \mathrm{H}$ NMR $\left(500 \mathrm{MHz}, \mathrm{DMSO}-d_{6}\right) \delta(\mathrm{ppm}) 10.13(\mathrm{~s}, 1 \mathrm{H}, 6-\mathrm{NH}), 9.87$ (s, $1 \mathrm{H}, 3-\mathrm{NH}), 7.59$ (t, $J=1.3 \mathrm{~Hz}, 1 \mathrm{H}, \mathrm{Ar}-\mathrm{H}), 7.39$ (d, $J=1.3 \mathrm{~Hz}$, $2 \mathrm{H}, 2 \times \mathrm{Ar}-\mathrm{H}), 6.25(\mathrm{~s}, 1 \mathrm{H}, 1-\mathrm{NH}), 4.49$ (d, J = $1.2 \mathrm{~Hz}, 1 \mathrm{H}, 5-$ $\mathrm{H}), 3.28-3.10\left(\mathrm{~m}, 2 \mathrm{H}, \mathrm{NHCH}_{2}\right), 2.90(\mathrm{t}, J=7.1 \mathrm{~Hz}, 2 \mathrm{H}, \mathrm{Ar}-$ $\left.\mathrm{CH}_{2}\right) ;{ }^{13} \mathrm{C}$ NMR (126 MHz, DMSO- $\left.d_{6}\right) \delta 164.35$ (4-C), 154.03 (2-C), 150.94 (6-C), 135.48 ( $\mathrm{Ar}-\mathrm{C}), 134.25$ ( $\mathrm{Ar}-\mathrm{C}), 132.68$ (Ar-C), 132.11 (Ar-C), $128.81(\mathrm{Ar}-\mathrm{C}), 127.60$ (Ar-C), 72.92 $\left(\mathrm{NHCH}_{2}\right), 31.53\left(\mathrm{Ar}-\mathrm{CH}_{2}\right) ; \mathrm{LC}-\mathrm{MS}(\mathrm{m} / z)$ : positive mode $299[\mathrm{M}+\mathrm{H}]^{1+}$; purity by HPLC-UV (254 nm)-ESI-MS: >99.0\%. $\mathrm{mp}:>300{ }^{\circ} \mathrm{C}$.

6-(1H-Indol-3-ylethylamino)-2,4(1H,3H)-pyrimidinedione (62). Compound 62 was synthesized using 6-chlorouracil (11, 10 $\mathrm{mmol}$ ) and 1-(indol-3-yl)ethylamine (50 mmol, 5 equiv) and was isolated as a white solid (93\% yield). ${ }^{1} \mathrm{H}$ NMR (500 MHz, DMSO- $\left.d_{6}\right) \delta(\mathrm{ppm}) 10.11(\mathrm{~s}, 1 \mathrm{H}, 1-\mathrm{NH}), 7.53(\mathrm{dd}, J=8.1,1.0$ $\mathrm{Hz}, 1 \mathrm{H}, \mathrm{Ar}-\mathrm{H}), 7.34(\mathrm{dt}, J=8.1,0.9 \mathrm{~Hz}, 1 \mathrm{H}, \mathrm{Ar}-\mathrm{H}), 7.19$ (d, $J=$ $2.4 \mathrm{~Hz}, 1 \mathrm{H}, \mathrm{Ar}-\mathrm{H}$ ), 7.07 (ddd, $J=8.1,6.9,1.2 \mathrm{~Hz}, 1 \mathrm{H}, \mathrm{Ar}-\mathrm{H}$ ), 6.98 (dd, $J=8.0,6.9, \mathrm{~Hz}, 1 \mathrm{H}, \mathrm{Ar}-\mathrm{H}), 4.48(\mathrm{~d}, J=1.4 \mathrm{~Hz}, 1 \mathrm{H}, 5-$ $\mathrm{H})$, 3.34-3.30 (m, 2H, $\left.\mathrm{NHCH}_{2}\right), 2.99-2.86\left(\mathrm{~m}, 2 \mathrm{H}, \mathrm{Ar}-\mathrm{CH}_{2}\right)$; ${ }^{13} \mathrm{C}$ NMR (126 MHz, DMSO-d $) \delta 164.38$ (4-C), 154.08 (2-C), 150.91 (6-C), 136.45 ( $\mathrm{Ar}-\mathrm{C}), 127.20(\mathrm{Ar}-\mathrm{C}), 123.32(\mathrm{Ar}-\mathrm{C})$, 121.16 (Ar-C), 118.48 (Ar-C), $118.34(\mathrm{Ar}-\mathrm{C}), 111.56$ (Ar-C), 110.96 (Ar-C), 72.72 (5-C), $42.01\left(\mathrm{NHCH}_{2}\right), 24.20$ $\left(\mathrm{Ar}-\mathrm{CH}_{2}\right) ; \mathrm{LC}-\mathrm{MS}(\mathrm{m} / z)$ : positive mode $270[\mathrm{M}+\mathrm{H}]^{1+}$; 
purity by HPLC-UV (254 nm)-ESI-MS: >96.0\%. mp: 270-272 ${ }^{\circ} \mathrm{C}$.

6-(Thiophen-2-yl)ethylamino-2,4(1H,3H)-pyrimidinedione (63). Compound 63 was synthesized using 6-chlorouracil (11, 10 mmol) and 2-thiopheneethylamine (50 mmol, 5 equiv) and was isolated as a yellow solid (97\% yield). ${ }^{1} \mathrm{H}$ NMR $(500 \mathrm{MHz}$, DMSO- $\left.d_{6}\right) \delta(\mathrm{ppm}) 7.32$ (dd, $\left.J=25.5,5.1, \mathrm{~Hz}, 1 \mathrm{H}, \mathrm{Ar}-\mathrm{H}\right), 6.95$ (dd, $J=14.4,5.0, \mathrm{~Hz}, 2 \mathrm{H}, 2 \times \mathrm{Ar}-\mathrm{H}), 6.29(\mathrm{~s}, 1 \mathrm{H}, 3-\mathrm{NH}), 4.45$ (s, $1 \mathrm{H}, 5-\mathrm{H}), 3.01\left(\mathrm{t}, J=6.9 \mathrm{~Hz}, 2 \mathrm{H}, \mathrm{NHCH}_{2}\right), 2.90-2.65(\mathrm{~m}$, $\left.2 \mathrm{H}, \mathrm{Ar}-\mathrm{CH}_{2}\right) ;{ }^{13} \mathrm{C}$ NMR (126 MHz, DMSO- $\left.d_{6}\right) \delta 164.40$ (4-C), 154.44 (2-C), 142.39 (6-C), 140.97 ( $\mathrm{Ar}-\mathrm{C}), 127.17$ ( $\mathrm{Ar}-\mathrm{C})$, $127.02(\mathrm{Ar}-\mathrm{C}), 125.72(\mathrm{Ar}-\mathrm{C}), 123.84(\mathrm{Ar}-\mathrm{C}), 72.86$ (5-C), $43.52\left(\mathrm{NHCH}_{2}\right), 28.54\left(\mathrm{Ar}-\mathrm{CH}_{2}\right)$; LC-MS $(\mathrm{m} / z)$ : positive mode $237[\mathrm{M}+\mathrm{H}]^{1+}$; purity by HPLC-UV (254 nm)-ESI-MS: 95.5\%. mp: $271-273{ }^{\circ} \mathrm{C}$.

6-(2-Phenoxyethylamino)-2,4(1H,3H)-pyrimidinedione (64). Compound 64 was synthesized using 6 -chlorouracil $(11,10$ $\mathrm{mmol}$ ) and 2-phenoxyethylamine ( $50 \mathrm{mmol}, 5$ equiv) and was isolated as a pale yellow solid (87\% yield). ${ }^{1} \mathrm{H}$ NMR $(600 \mathrm{MHz}$, DMSO- $\left.d_{6}\right) \delta(\mathrm{ppm}) 10.17$ (s, 1H, 3-NH), 7.33-7.25 (m, 2H, $2 \times$ $\mathrm{Ar}-\mathrm{H}), 6.97-6.90(\mathrm{~m}, 3 \mathrm{H}, 3 \times \mathrm{Ar}-\mathrm{H}), 4.52(\mathrm{~d}, J=1.6 \mathrm{~Hz}, 1 \mathrm{H}$, $5-\mathrm{H}), 4.08\left(\mathrm{t}, J=5.2 \mathrm{~Hz}, 2 \mathrm{H}, \mathrm{OCH}_{2}\right), 3.40(\mathrm{q}, J=5.3 \mathrm{~Hz}, 2 \mathrm{H}$, $\left.\mathrm{NHCH}_{2}\right) ;{ }^{13} \mathrm{C}$ NMR $\left(151 \mathrm{MHz}, \mathrm{DMSO}-d_{6}\right) \delta 164.36$ (4-C), 158.32 (2-C), 154.19 (6-C), 150.87 (Ar-Ar-C), 129.71 (ArC), $129.60(\mathrm{Ar}-\mathrm{C}), 121.07(\mathrm{Ar}-\mathrm{C}), 114.69(\mathrm{Ar}-\mathrm{C}), 73.09$ $(\mathrm{Ar}-\mathrm{C}), 65.77$ (5-C), $41.11\left(\mathrm{NHCH}_{2}\right), 40.99\left(\mathrm{OCH}_{2}\right)$; LC-MS $(\mathrm{m} / z)$ : positive mode $247[\mathrm{M}+\mathrm{H}]^{1+}$; purity by HPLC-UV $(254$ nm)-ESI-MS: $97.0 \%$. mp: $>300{ }^{\circ} \mathrm{C}$.

6-(3-Phenoxypropylamino)-2,4(1H,3H)-pyrimidinedione (65). Compound 65 was synthesized using 6-chlorouracil (11, 10 $\mathrm{mmol}$ ) and 3-phenoxypropylamine ( $50 \mathrm{mmol}, 5$ equiv) and was isolated as a light yellow solid (90\% yield). ${ }^{1} \mathrm{H} \mathrm{NMR}(500 \mathrm{MHz}$, DMSO- $\left.d_{6}\right) \delta(\mathrm{ppm}) 7.38-7.13(\mathrm{~m}, 2 \mathrm{H}, 2 \times \mathrm{Ar}-\mathrm{H}), 6.99-6.75$ $(\mathrm{m}, 3 \mathrm{H}, 3 \times \mathrm{Ar}-\mathrm{H}), 4.42(\mathrm{~s}, 1 \mathrm{H}, 5-\mathrm{H}), 4.01(\mathrm{td}, J=6.2,1.9 \mathrm{~Hz}$, $\left.2 \mathrm{H}, \mathrm{OCH}_{2}\right), 3.16\left(\mathrm{q}, J=6.3 \mathrm{~Hz}, 2 \mathrm{H}, \mathrm{NHCH}_{2}\right), 1.88-1.87(\mathrm{~m}$, $\left.2 \mathrm{H}, \mathrm{CH}_{2}\right) ;{ }^{13} \mathrm{C}$ NMR (126 MHz, DMSO-d $) \delta 164.50$ (4-C), 158.58 (2-C), 155.43 (6-C), 129.57 ( $\mathrm{Ar}-\mathrm{C}), 129.54(\mathrm{Ar}-\mathrm{C})$, 120.67 (Ar-C), $120.57(\mathrm{Ar}-\mathrm{C}), 114.53(\mathrm{Ar}-\mathrm{C}), 72.60(\mathrm{Ar}-\mathrm{C})$, $65.08(5-\mathrm{C}), 38.57\left(\mathrm{NHCH}_{2}\right), 37.99\left(\mathrm{OCH}_{2}\right), 28.06\left(\mathrm{CH}_{2}\right)$; LC-MS $(m / z)$ : positive mode $261[\mathrm{M}+\mathrm{H}]^{1+}$; purity by HPLCUV (254 nm)-ESI-MS: $95.4 \%$. mp: $180-182{ }^{\circ} \mathrm{C}$.

6-(4-Benzylpiperidin-1yl)-2,4(1H,3H)-pyrimidinedione (67). Compound 67 was synthesized using 6-chlorouracil (11, 10 $\mathrm{mmol}$ ) and 4-benzylpiperidine (50 mmol, 5 equiv) and was isolated as a white solid (81\% yield). ${ }^{1} \mathrm{H}$ NMR $(600 \mathrm{MHz}$, DMSO- $\left.d_{6}\right) \delta(\mathrm{ppm}) 10.29(\mathrm{~d}, J=14.0 \mathrm{~Hz}, 2 \mathrm{H}, 2 \times \mathrm{NH}), 7.27(\mathrm{t}, J$ $=7.5 \mathrm{~Hz}, 2 \mathrm{H}, 2 \times \mathrm{Ar}-\mathrm{H}), 7.21-7.01(\mathrm{~m}, 3 \mathrm{H}, 3 \times \mathrm{Ar}-\mathrm{H}), 4.60$ $(\mathrm{d}, J=1.5 \mathrm{~Hz}, 1 \mathrm{H}, 5-\mathrm{H}), 3.70\left(\mathrm{dt}, J=12.6,2.3 \mathrm{~Hz}, 2 \mathrm{H}, \mathrm{N}-\mathrm{CH}_{2}\right)$, $2.71\left(\mathrm{dd}, J=12.8,2.6 \mathrm{~Hz}, 2 \mathrm{H}, \mathrm{N}-\mathrm{CH}_{2}\right), 2.50(\mathrm{~d}, J=7.0 \mathrm{~Hz}, 2 \mathrm{H}$, $\left.\mathrm{CH}_{2}\right), 1.83-1.39\left(\mathrm{~m}, 3 \mathrm{H}, \mathrm{CH}\right.$ and $\left.\mathrm{CH}_{2}\right), 1.37-0.87(\mathrm{~m}, 2 \mathrm{H}$, $\left.\mathrm{CH}_{2}\right) ;{ }^{13} \mathrm{C}$ NMR (151 MHz, DMSO- $\left.d_{6}\right) \delta 164.38$ (4-C), 155.46 (2-C), 151.67 (6-C), 140.13 (Ar-C), 129.14 (Ar-C), 128.32 (Ar-C), $125.99(\mathrm{Ar}-\mathrm{C}), 77.51(5-\mathrm{C}), 46.70\left(\mathrm{~N}-\mathrm{CH}_{2}\right), 42.03$ $\left(\mathrm{N}-\mathrm{CH}_{2}\right), 37.06\left(\mathrm{Ar}-\mathrm{CH}_{2}\right), 30.87\left(2 \times \mathrm{CH}_{2}\right) ; \mathrm{LC}-\mathrm{MS}(\mathrm{m} / \mathrm{z})$ : positive mode $285[\mathrm{M}+\mathrm{H}]^{1+}$; purity by HPLC-UV $(254 \mathrm{~nm})$ ESI-MS: $>99.0 \%$. mp: $277-279^{\circ} \mathrm{C}$.

6-[4-(p-Chlorophenyl)-1-piperazinyl]-2,4(1H,3H)-pyrimidinedione (68). Compound 68 was synthesized using 6chlorouracil $(11,10 \mathrm{mmol})$ and 1-(p-chlorophenyl)piperazine ( $50 \mathrm{mmol}, 5$ equiv) and was isolated as a white solid (76\% yield). ${ }^{1} \mathrm{H}$ NMR (500 MHz, DMSO- $\left.d_{6}\right) \delta$ (ppm) 10.41 (s, 1H, 3-NH), 7.30-7.18 (m, 2H, $2 \times$ Ar-H), 7.03-6.93 (m, 2H, $2 \times$ Ar-H), $4.70(\mathrm{~d}, J=1.3 \mathrm{~Hz}, 1 \mathrm{H}, 5-\mathrm{H}), 3.40-3.32\left(\mathrm{~m}, 4 \mathrm{H}, 2 \times \mathrm{N}-\mathrm{CH}_{2}\right)$, $3.18\left(\mathrm{dd}, J=6.5,3.8 \mathrm{~Hz}, 4 \mathrm{H}, 2 \times \mathrm{N}-\mathrm{CH}_{2}\right) ;{ }^{13} \mathrm{C} \mathrm{NMR}(126 \mathrm{MHz}$, DMSO-d $\left.d_{6}\right) \delta 164.33$ (4-C), 155.68 (2-C), 151.56 (6-C), 149.48 (Ar-C), $149.01(\mathrm{Ar}-\mathrm{C}), 128.94(\mathrm{Ar}-\mathrm{C}), 128.81(\mathrm{Ar}-\mathrm{C})$, $122.94(\mathrm{Ar}-\mathrm{C}), 117.68(\mathrm{Ar}-\mathrm{C}), 78.24(5-\mathrm{C}), 47.47\left(\mathrm{~N}-\mathrm{CH}_{2}\right)$, $46.05\left(\mathrm{~N}-\mathrm{CH}_{2}\right), 45.49\left(\mathrm{~N}-\mathrm{CH}_{2}\right), 42.65\left(\mathrm{~N}-\mathrm{CH}_{2}\right)$. LC-MS $(\mathrm{m} / \mathrm{z})$ : positive mode $307[\mathrm{M}+\mathrm{H}]^{1+}$; purity by HPLC-UV $(254$ nm)-ESI-MS: $95.0 \%$. mp: $279-281{ }^{\circ} \mathrm{C}$.

6-[4-(2,3-Dihydro-1H-inden-2-yl)-1-piperazinyl]-2,4$(1 \mathrm{H}, 3 \mathrm{H})$-pyrimidinedione (70). Compound $\mathbf{7 0}$ was synthesized using 6-chlorouracil $(\mathbf{1 1}, 10 \mathrm{mmol})$ and 4-(2,3-dihydro- $1 \mathrm{H}$ inden-2-yl)-1-piperazine ( $50 \mathrm{mmol}, 5$ equiv) and was isolated as a white solid (84\% yield). ${ }^{1} \mathrm{H}$ NMR (500 MHz, DMSO- $\left.d_{6}\right) \delta$ (ppm) $7.26(\mathrm{dd}, J=7.1,3.4 \mathrm{~Hz}, 1 \mathrm{H}, \mathrm{Ar}-\mathrm{H}), 7.22(\mathrm{dd}, J=6.3,2.3$ $\mathrm{Hz}, 1 \mathrm{H}, \mathrm{Ar}-\mathrm{H}$ ), 7.18 (dd, $J=7.6,6.8,3.9 \mathrm{~Hz}, 2 \mathrm{H}, 2 \times \mathrm{Ar}-\mathrm{H})$, $4.62(\mathrm{~s}, 1 \mathrm{H}, 5-\mathrm{H}), 4.46-3.97(\mathrm{~m}, 1 \mathrm{H}, \mathrm{CH}), 3.21(\mathrm{dt}, J=6.2,3.9$ $\left.\mathrm{Hz}, 4 \mathrm{H}, 2 \times \mathrm{N}-\mathrm{CH}_{2}\right), 2.81-2.79\left(\mathrm{~m}, 2 \mathrm{H}, 2 \times \mathrm{N}-\mathrm{CH}_{2}\right), 2.38-$ $2.36\left(\mathrm{~m}, 2 \mathrm{H}, \mathrm{Ar}-\mathrm{CH}_{2}\right), 1.99\left(\mathrm{q}, J=7.2 \mathrm{~Hz}, 2 \mathrm{H}, \mathrm{Ar}-\mathrm{CH}_{2}\right) ;{ }^{13} \mathrm{C}$ NMR (126 MHz, DMSO-d $) \delta 164.32$ (4-C), 155.76 (2-C), 151.57 (6-C), $143.84(\mathrm{Ar}-\mathrm{C}), 142.32$ ( $\mathrm{Ar}-\mathrm{C}), 127.59$ ( $\mathrm{Ar}-\mathrm{C})$, 126.23 ( $\mathrm{Ar}-\mathrm{C}), 125.12$ ( $\mathrm{Ar}-\mathrm{C}), 124.76(\mathrm{Ar}-\mathrm{C}), 77.91$ (5-C), $69.05(\mathrm{~N}-\mathrm{CH}), 47.54\left(\mathrm{~N}-\mathrm{CH}_{2}\right), 46.74\left(\mathrm{~N}-\mathrm{CH}_{2}\right), 30.47(2 \times$ $\left.\mathrm{N}-\mathrm{CH}_{2}\right), 24.33\left(2 \times \mathrm{Ar}-\mathrm{CH}_{2}\right) ; \mathrm{LC}-\mathrm{MS}(\mathrm{m} / z)$ : positive mode $312[\mathrm{M}+\mathrm{H}]^{1+}$; purity by HPLC-UV (254 nm)-ESI-MS: $98.0 \%$. mp: $280-282^{\circ} \mathrm{C}$.

6-[4-(1-Naphthylmethyl)-1-piperazinyl]-2,4(1H,3H)-pyrimidinedione (71). Compound 71 was synthesized using 6chlorouracil $(11,10 \mathrm{mmol})$ and 1-(1-naphthylmethyl)piperazine (50 mmol, 5 equiv) and was isolated as a pale brown solid (82\% yield). ${ }^{1} \mathrm{H}$ NMR (500 MHz, DMSO- $\left.d_{6}\right) \delta(\mathrm{ppm}) 8.27$ (dd, $J=$ 7.8, 1.5 Hz, 1H, Ar-H), 7.98-7.77 (m, 2H,2 × Ar-H), 7.63$7.48(\mathrm{~m}, 2 \mathrm{H}, 2 \times \mathrm{Ar}-\mathrm{H}), 7.48-7.37(\mathrm{~m}, 2 \mathrm{H}, 2 \times \mathrm{Ar}-\mathrm{H}), 4.63(\mathrm{~d}$, $J=1.3 \mathrm{~Hz}, 1 \mathrm{H}), 3.90\left(\mathrm{~s}, 2 \mathrm{H}, \mathrm{Ar}-\mathrm{CH}_{2}-\mathrm{N}\right), 3.20(\mathrm{t}, J=5.0 \mathrm{~Hz}$, $\left.4 \mathrm{H}, 2 \times \mathrm{N}-\mathrm{CH}_{2}\right), 2.47\left(\mathrm{~d}, \mathrm{~J}=4.9 \mathrm{~Hz}, 4 \mathrm{H}, 2 \times \mathrm{N}-\mathrm{CH}_{2}\right) ;{ }^{13} \mathrm{C}$ NMR (126 MHz, DMSO-d $)_{6} \delta 164.32$ (4-C), 155.79 (2-C), 151.56 (6-C), 133.62 ( $\mathrm{Ar}-\mathrm{C}), 132.15$ ( $\mathrm{Ar}-\mathrm{C}), 128.38$ ( $\mathrm{Ar}-\mathrm{C})$, 128.01 ( $\mathrm{Ar}-\mathrm{C}), 127.64(\mathrm{Ar}-\mathrm{C}), 125.97$ ( $\mathrm{Ar}-\mathrm{C}), 125.83$ ( $\mathrm{Ar}-$ C), 125.31 ( $\mathrm{Ar}-\mathrm{C}), 124.87(\mathrm{Ar}-\mathrm{C}), 78.04$ (5-C), 60.02 (Ar$\left.\mathrm{CH}_{2}-\mathrm{N}\right), 52.07\left(2 \times \mathrm{N}-\mathrm{CH}_{2}\right), 46.40\left(2 \times \mathrm{N}-\mathrm{CH}_{2}\right) ; \mathrm{LC}-\mathrm{MS}$ $(\mathrm{m} / \mathrm{z})$ : positive mode $336[\mathrm{M}+\mathrm{H}]^{1+}$; purity by HPLC-UV $(254$ nm)-ESI-MS: $97.0 \%$. mp: $240-242{ }^{\circ} \mathrm{C}$.

5-Bromo-6-octylamino-2,4(1H,3H)-pyrimidinedione (73). Compound 73 was synthesized using $6(10 \mathrm{mmol})$ in pyridine $(2 \mathrm{~mL})$ and $\mathrm{N}$-bromosuccinimide $(12 \mathrm{mmol})$ and was isolated as a yellow solid (89\% yield). ${ }^{1} \mathrm{H}$ NMR (500 MHz, DMSO- $\left.d_{6}\right) \delta$ (ppm) $3.22\left(\mathrm{q}, J=7.1 \mathrm{~Hz}, 2 \mathrm{H}, \mathrm{NHCH}_{2}\right), 1.41(\mathrm{p}, J=6.8,6.4 \mathrm{~Hz}$, $\left.2 \mathrm{H}, \mathrm{CH}_{2}\right), 1.31-1.15\left(\mathrm{~m}, 10 \mathrm{H}, 5 \times \mathrm{CH}_{2}\right), 0.85(\mathrm{t}, J=6.8 \mathrm{~Hz}, 3 \mathrm{H}$, $\left.\mathrm{CH}_{3}\right) ;{ }^{13} \mathrm{C}$ NMR (126 MHz, DMSO-d $\left.d_{6}\right) \delta 164.15$ (4-C), 159.30 (2-C), 152.20 (6-C), 97.76 (5-C), $31.33\left(\mathrm{NH}-\mathrm{CH}_{2}\right), 29.64$ $\left(\mathrm{CH}_{2}\right), 29.23\left(\mathrm{CH}_{2}\right), 28.73\left(\mathrm{CH}_{2}\right), 28.71\left(\mathrm{CH}_{2}\right), 28.57\left(\mathrm{CH}_{2}\right)$, $26.03\left(\mathrm{CH}_{2}\right), 22.18\left(\mathrm{CH}_{2}\right), 14.07\left(\mathrm{CH}_{3}\right)$; LC-MS $(\mathrm{m} / \mathrm{z})$ : positive mode $316[\mathrm{M}+\mathrm{H}]^{1+}$; purity by HPLC-UV $(254 \mathrm{~nm})$ ESI-MS: $>97.0 \%$. $\mathrm{mp}:>300{ }^{\circ} \mathrm{C}$.

5-Bromo-6-(p-bromophenylethylamino)-2,4(1H,3H)-pyrimidinedione (74). Compound 74 was synthesized using 48 (10 $\mathrm{mmol})$ in pyridine $(2 \mathrm{~mL})$ and $\mathrm{N}$-bromosuccinimide $(12 \mathrm{mmol})$ and was isolated as a yellow solid (97\% yield). ${ }^{1} \mathrm{H}$ NMR (600 $\left.\mathrm{MHz}, \mathrm{DMSO}-d_{6}\right) \delta$ (ppm) 8.30-8.18 (m, 2H, $\left.2 \times \mathrm{Ar}-\mathrm{H}\right), 7.26-$ $7.15(\mathrm{~m}, 2 \mathrm{H}, 2 \times \mathrm{Ar}-\mathrm{H}), 3.47(\mathrm{dt}, J=7.9,6.3 \mathrm{~Hz}, 2 \mathrm{H}, \mathrm{NH}-$ $\left.\mathrm{CH}_{2}\right), 2.70\left(\mathrm{t}, J=7.3 \mathrm{~Hz}, 2 \mathrm{H}, \mathrm{Ar}-\mathrm{CH}_{2}\right) ;{ }^{13} \mathrm{C}$ NMR $(151 \mathrm{MHz}$, DMSO- $d_{6}$ ) $\delta 160.17$ (4-C), 150.14 (2-C), 147.19 (6-C), 137.96 (Ar-C), $131.36(\mathrm{Ar}-\mathrm{C}), 129.12(\mathrm{Ar}-\mathrm{C}), 119.67$ (Ar-C), 97.95 (5-C), $42.40\left(\mathrm{NH}-\mathrm{CH}_{2}\right), 34.60\left(\mathrm{Ar}-\mathrm{CH}_{2}\right) ; \mathrm{LC}-\mathrm{MS}(\mathrm{m} / \mathrm{z})$ : 
positive mode $387[\mathrm{M}-2 \mathrm{H}]^{2-}$ and $389[\mathrm{M}-\mathrm{H}]^{1-}$; purity by HPLC-UV (254 nm)-ESI-MS: $96.0 \%$. mp: $>300{ }^{\circ} \mathrm{C}$.

6-Heptylamino-5-nitroso-2,4(1H,3H)-pyrimidinedione (77). Compound 77 was synthesized using $21(10 \mathrm{mmol})$ and was isolated as a pink solid (68\% yield). ${ }^{1} \mathrm{H}$ NMR (500 MHz, DMSO- $\left.d_{6}\right) \delta(\mathrm{ppm}) 3.34-3.36\left(\mathrm{~m}, 2 \mathrm{H}, \mathrm{NHCH}_{2}\right) 1.50-1.48(\mathrm{~m}$, $\left.2 \mathrm{H}, \mathrm{CH}_{2}\right), 1.38-1.07\left(\mathrm{~m}, 8 \mathrm{H}, 4 \times \mathrm{CH}_{2}\right), 0.86(\mathrm{t}, J=6.7 \mathrm{~Hz}, 3 \mathrm{H}$, $\left.\mathrm{CH}_{3}\right) ;{ }^{13} \mathrm{C}$ NMR (126 MHz, DMSO-d $\left.d_{6}\right) \delta 162.99$ (4-C), 154.53 (2-C), 152.10 (6-C), $79.16(5-\mathrm{C}), 31.31\left(\mathrm{NHCH}_{2}\right), 28.14$ $\left(\mathrm{CH}_{2}\right), 27.12\left(\mathrm{CH}_{2}\right), 26.50\left(\mathrm{CH}_{2}\right), 25.85\left(\mathrm{CH}_{2}\right), 22.15\left(\mathrm{CH}_{2}\right)$, $14.05\left(\mathrm{CH}_{3}\right)$; LC-MS $(\mathrm{m} / z)$ : positive mode $254[\mathrm{M}+\mathrm{H}]^{1+}$; purity by HPLC-UV (254 nm)-ESI-MS: >96.0\%. mp: 210-212 ${ }^{\circ} \mathrm{C}$.

5-Nitroso-6-octylamino-2,4(1H,3H)-pyrimidinedione (78). Compound 78 was synthesized using $6(10 \mathrm{mmol})$ and was isolated as a pink solid (73\% yield). ${ }^{1} \mathrm{H}$ NMR $(500 \mathrm{MHz}$, DMSO$\left.d_{6}\right) \delta 10.74(\mathrm{~s}, 1 \mathrm{H}, 1-\mathrm{NH}), 7.59(\mathrm{~s}, 1 \mathrm{H}, 3-\mathrm{NH}), 3.35(\mathrm{q}, J=6.7$ $\mathrm{Hz}, 2 \mathrm{H}), 1.51(\mathrm{p}, J=7.1 \mathrm{~Hz}, 2 \mathrm{H}), 1.35-1.08(\mathrm{~m}, 10 \mathrm{H}), 0.85(\mathrm{t}, J$ $=6.7 \mathrm{~Hz}, 3 \mathrm{H}) ;{ }^{13} \mathrm{C}$ NMR $(126 \mathrm{MHz}$, DMSO-d 6 ) $\delta 161.74(4-\mathrm{C})$, 151.88 (2-C), 149.19 (6-C), $138.22(5-\mathrm{C}), 31.32\left(\mathrm{NHCH}_{2}\right)$, 28.31, 27.11, 26.33, 25.89, $22.18\left(6 \times \mathrm{CH}_{2}\right), 14.06\left(\mathrm{CH}_{3}\right)$; LCMS $(\mathrm{m} / z)$ : positive mode $267[\mathrm{M}+\mathrm{H}]^{1+}$; purity by HPLC-UV (254 nm)-ESI-MS: $>99.0 \%$. mp: $171-173{ }^{\circ} \mathrm{C}$.

5-Nitroso 6-(3-phenylpropylamino)-2,4(1H,3H)-pyrimidinedione (80). Compound 80 was synthesized using 43 (10 $\mathrm{mmol}$ ) and was isolated as a light purple solid (72\% yield). ${ }^{1} \mathrm{H}$ NMR (500 MHz, DMSO- $d_{6}$ ) $\delta 10.67$ (s, $\left.1 \mathrm{H}, 1-\mathrm{NH}\right), 7.33-7.24$ $(\mathrm{m}, 2 \mathrm{H}), 7.23-7.13(\mathrm{~m}, 3 \mathrm{H}), 3.36(\mathrm{q}, J=6.7 \mathrm{~Hz}, 2 \mathrm{H}), 2.62(\mathrm{q}, J=$ $7.7 \mathrm{~Hz}, 2 \mathrm{H}), 1.89-1.79(\mathrm{~m}, 2 \mathrm{H}) ;{ }^{13} \mathrm{C}$ NMR $(126 \mathrm{MHz}, \mathrm{DMSO}-$ $\left.d_{6}\right) \delta 163.58$ (4-C), 161.90 (2-C), 141.20 (6-C), 138.32 (5-C), 128.59 ( $\mathrm{Ar}-\mathrm{C}), 128.49(\mathrm{Ar}-\mathrm{C}), 128.40(\mathrm{Ar}-\mathrm{C}), 128.36(\mathrm{Ar}-$ C), 126.21 ( $\mathrm{Ar}-\mathrm{C}), 126.03(\mathrm{Ar}-\mathrm{C}), 41.21\left(\mathrm{Ar}-\mathrm{CH}_{2}\right), 30.03$ $\left(\mathrm{NHCH}_{2}\right), 29.41\left(\mathrm{CH}_{2}\right) ; \mathrm{LC}-\mathrm{MS}(\mathrm{m} / z)$ : positive mode $274[\mathrm{M}$ $+\mathrm{H}]^{1+}$; purity by HPLC-UV (254 nm)-ESI-MS: $95.0 \%$. mp: $212-214^{\circ} \mathrm{C}$.

Biological Assays. The recombinant $\mathrm{CHO}$ cell line expressing the human GPR84 (CHO-hGPR84 cells) with a $\beta$ galactosidase fragment and $\beta$-arrestin 2 containing the complementary fragment of the enzyme for performing $\beta$ arrestin recruitment (Pathhunter) was purchased from DiscoverX (Fremont, CA). The CHO-hGPR84 cells were cultured in F12 medium supplemented with $10 \%$ FCS, 100 units $/ \mathrm{mL}$ penicillin G, $100 \mu \mathrm{g} / \mathrm{mL}$ streptomycin, $800 \mu \mathrm{g} / \mathrm{mL} \mathrm{G} \mathrm{418,} 300$ $\mu \mathrm{g} / \mathrm{mL}$ hygromycin $\mathrm{B}$, and $1 \%$ ultraglutamin (Invitrogen, Carlsbad, CA, or Sigma-Aldrich, St. Louis, MO). Stock solutions of compounds were prepared in DMSO. The final DMSO concentration in the assays did not exceed $1 \%$. Data analysis was performed using GraphPad Prism (version 6.02). Concentration-response data were fitted by nonlinear regression to estimate $\mathrm{EC}_{50}$ values (Prism 6.02). The unpaired $t$ test was used for statistical comparisons. Pathway bias was calculated as described by Winpenny et al. ${ }^{33} \Delta \log \left(E_{\max } / \mathrm{EC}_{50}\right)$ was calculated by the following equation: $\Delta \log \left(E_{\max } / E_{50}\right)=\log \left(E_{\max } B /\right.$ $\left.\mathrm{EC}_{50} B\right)-\log \left(E_{\max } \mathrm{A} / \mathrm{EC}_{50} \mathrm{~A}\right)$, where $\mathrm{A}$ is the reference agonist decanoic acid and $\mathrm{B}$ is the test compound. $\Delta \Delta \log \left(E_{\max } / \mathrm{EC}_{50}\right)$ was determined using the following equation: $\Delta \Delta \log \left(E_{\max } /\right.$ $\left.\mathrm{EC}_{50}\right)=\Delta \log \left(E_{\max } / \mathrm{EC}_{50}\right)_{\text {Gi pathway }}-\Delta \log \left(E_{\max } /\right.$ $\left.\mathrm{EC}_{50}\right)_{\text {B-arrestin pathway. }}$

GPR84 CAMP Accumulation Assays. cAMP assays were performed as previously described. ${ }^{26,35}$ In short, CHO-hGPR84 cells were stimulated by the addition of forskolin $(10 \mu \mathrm{M})$ in the absence (control) or presence of test compounds for $15 \mathrm{~min}$. The reaction was stopped with hot $\left(90^{\circ} \mathrm{C}\right)$ lysis solution $(4 \mathrm{mM}$ ethylenediaminetetraacetic acid, $0.01 \%$ Triton X-100 in water). cAMP levels were quantified by a radioactive assay using $\left[{ }^{3} \mathrm{H}\right]$ cAMP (PerkinElmer, Rodgau, Germany) and a cAMPbinding protein prepared from bovine adrenal medulla. The forskolin-induced increase in cAMP concentration in the presence of agonists was expressed as a percentage of the response to forskolin in the absence of agonists (\% of control). Three independent experiments, each in duplicate, were performed.

GPR84 $\beta$-Arrestin Recruitment Assays. $\beta$-Arrestin assays were performed as previously described. ${ }^{26}$ Briefly, $\mathrm{CHO}$ hGPR84 cells (20 000 per well) were incubated with compound dilutions (in DMSO, final concentration: 1\%) for $90 \mathrm{~min}$ before adding the detection reagent (DiscoverX). After $60 \mathrm{~min}$ of incubation at $\mathrm{rt}$, the luminescence was measured using an NXT plate reader (PerkinElmer, Meriden, CT). Three to five independent experiments were performed, each in duplicate.

FFAR4 $\boldsymbol{\beta}$-Arrestin Recruitment Assays. $\beta$-Arrestin assays were performed as previously described. ${ }^{26}$ In brief, $\mathrm{CHO}$ hFFAR4 cells were incubated with test compound or the reference agonist 4-[(4-fluoro-4'-methyl[1,1'-biphenyl]-2-yl)methoxy] benzenepropanoic acid (TUG-891) for $90 \mathrm{~min}$. In antagonist assays, the cells were preincubated with the antagonist for $30 \mathrm{~min}$ before adding the reference agonist. Next, the detection reagent was added and the mixture was incubated for $60 \mathrm{~min}$ at $\mathrm{rt}$. The luminescence was measured using an NXT plate reader (PerkinElmer, Meriden, CT). All compounds were tested at a final concentration of $10 \mu \mathrm{M}$. Test results were normalized to values obtained by determining the background and the signal induced by 30 and $4 \mu \mathrm{M}$ TUG- 891 in agonist and antagonist assays, respectively. Three to four independent experiments were performed in duplicate.

FFAR1 Calcium Mobilization Assay. $\beta$-Arrestin assays were performed as previously described. ${ }^{26}$ In brief, $1321 \mathrm{~N} 1$ astrocytoma cells recombinantly expressing human FFAR1 were incubated with Hank's balanced salt solution buffer solution supplemented with $3 \mu \mathrm{M}$ of the calcium dye Fluo-4-AM (Life Technologies, Darmstadt, Germany) and 0.06\% Pluronic F-127 for $60 \mathrm{~min}$. After exchanging the buffer, test compound solutions were added to each well using a FlexStation 3 plate reader (Molecular Devices, Sunnyvale, CA). In antagonist assays, cells were preincubated for $30 \mathrm{~min}$ with test compound solutions before adding the reference agonist 3-(4-(o-tolylethynyl)phenyl)propanoic acid (TUG-424, final concentration: $1 \mu \mathrm{M}$ $\left.\approx \mathrm{EC}_{80}\right)$. All compounds were tested at a final concentration of $10 \mu \mathrm{M}$. Signals induced by the test compounds were normalized to the signals induced by 1 and $10 \mu \mathrm{M}$ TUG-424 in antagonist and agonist assays, respectively. Three to four independent experiments were performed in duplicate.

Metabolic Stability. Pooled human liver microsomes (0.5 $\mathrm{mg} / \mathrm{mL}$, mixed gender, pooled) were employed. Compounds were tested at a concentration of $1 \mu \mathrm{M}$. These experiments were performed by Pharmacelsus (Contract Research Organisation), Saarbrücken, Germany. Data points represent means of two separate experiments performed in duplicate. Standard deviations were around $\pm 20 \%$.

Pharmacophore Modeling. The selected GPR84 agonists $2,4,6$, and 48 were flexibly aligned using the flexible alignment module implemented in Molecular Operating Environment (MOE 2014.09). ${ }^{36}$ The flexible alignment method utilizes the stochastic search procedure and simultaneously searches for the conformational space of the defined molecules and the space of alignment of those molecules. ${ }^{37}$ The method aligns the GPR84 
agonists by maximizing steric and feature overlap using the MMFF94x force field. ${ }^{38}$ Each resulting alignment is given a score that quantifies the quality of the alignment in terms of both internal strain and overlap of molecular features. The similarity terms, including hydrogen bond donor, acceptor, hydrophobicity, and volume, were used in the flexible alignment with the default settings for the other parameters. On the basis of the overall score, strain energy, and visual inspection of the alignment, the presented flexible alignment of the GPR84 agonists was selected. This alignment was then used as a template for the pharmacophore model generation. The pharmacophore model was generated using the pharmacophore elucidator feature in MOE 2014.09. The pharmacophore features were calculated automatically with the consensus pharmacophore function. This function clusters the features into potential pharmacophore features, which are more conserved than a tolerance and threshold value. For the presented pharmacophore model, a tolerance distance of $1.5 \AA$ and a threshold of $50 \%$ conservation were used.

\section{ASSOCIATED CONTENT}

\section{S Supporting Information}

The Supporting Information is available free of charge on the ACS Publications website at DOI: 10.1021/acsomega.7b02092.

Metabolic stability of compound $\mathbf{4 2}$ in liver microsomes (Figure S1); potency of GPR84 agonists at FFAR1 (Table S1) and FFAR4 receptors (Table S2); $\mathrm{pEC}_{50}$ values of GPR84 agonists determined in cAMP and $\beta$-arrestin assays (Table S3); synthesis, analysis, and ${ }^{1} \mathrm{H}$ and ${ }^{13} \mathrm{C}$ NMR spectra of final products (Figures S1-S60) (PDF) Details of human GPR84 (cAMP assay), human GPR84 ( $\beta$-arrestin assay), human FFAR1 (agonistic potency), human FFAR1 (antagonistic potency), human FFAR4 (agonistic potency), and human FFAR4 (antagonistic potency) (CSV)

\section{AUTHOR INFORMATION}

\section{Corresponding Author}

*E-mail: christa.mueller@uni-bonn.de. Phone: +49-228-732301. Fax: +49-228-73-2567.

\section{ORCID}

Thanigaimalai Pillaiyar: 0000-0001-5575-8896

Christa E. Müller: 0000-0002-0013-6624

\section{Notes}

The authors declare no competing financial interest.

\section{ACKNOWLEDGMENTS}

T.P. is grateful to the Alexander von Humboldt ( $\mathrm{AvH})$ Foundation and to Bayer Pharma for a postdoctoral fellowship. G.B. acknowledges the CAPES Foundation and the Ministry of Education of Brazil for supporting an internship. Expert technical contributions by Marion Schneider (LC-MS analyses), as well as Sabine Terhart-Krabbe and Annette Reiner (NMR studies) are gratefully acknowledged.

\section{ABBREVIATIONS}

GPCR, G protein-coupled receptor; cAMP, cyclic adenosine monophosphate; GPR, G protein-coupled receptor; FFA/R, free fatty acid/receptor; CHO, Chinese hamster ovary; SAR, structure-activity relationship; DIM, diindolylmethane; DMSO, dimethyl sulfoxide; NMR, nuclear magnetic resonance;
$\mathrm{C}_{\text {apt }}, \mathrm{C}$ compensated attached proton test; HPLC, highperformance liquid chromatography; LC-MS, liquid chromatography-mass spectrometry; ESI, electrospray ionization; TLC, thin-layer chromatography; DMF, $N, N^{\prime}$-dimethylformamide; mp, melting point; NBS, N-bromosuccinimide; PSB, Pharmaceutical Sciences Bonn

\section{REFERENCES}

(1) Fredriksson, R.; Schiöth, H. B. The repertoire of G-proteincoupled receptors in fully sequenced genomes. Mol. Pharmacol. 2005, $67,1414-1425$.

(2) Fredriksson, R.; Lagerström, M. C.; Lundin, L.-G.; Schiöth, H. B. The G-protein-coupled receptors in the human genome form five main families. Phylogenetic analysis, paralogon groups, and fingerprints. Mol. Pharmacol. 2003, 63, 1256-1272.

(3) Lagerström, M. C.; Schiöth, H. B. Structural diversity of G proteincoupled receptors and significance for drug discovery. Nat. Rev. Drug Discovery 2008, 7, 339-357.

(4) Overington, J. P.; Al-Lazikani, B.; Hopkins, A. L. How many drug targets are there? Nat. Rev. Drug Discovery 2006, 5, 993-996.

(5) Alexander, S. P. H.; Davenport, A. P.; Kelly, E.; Marrion, N.; Peters, J. A.; Benson, H. E.; Faccenda, E.; Pawson, A. J.; Sharman, J. L.; Southan, C.; Davies, J. A. The concise guide to pharmacology 2015/16: G protein-coupled receptors. Br. J. Pharmacol. 2015, 172, 5744-5869.

(6) Wittenberger, T.; Schaller, H. C.; Hellebrand, S. An expressed sequence tag (EST) data mining strategy succeeding in the discovery of new G-protein coupled receptors. J. Mol. Biol. 2001, 307, 799-813.

(7) Wang, J.; Wu, X.; Simonavicius, N.; Tian, H.; Ling, L. Medium chain fatty acids as ligands for orphan $\mathrm{G}$ protein-coupled receptor GPR84. J. Biol. Chem. 2006, 281, 34457-34464.

(8) Suzuki, M.; Takaishi, S.; Nagasaki, M.; Onozawa, Y.; Iino, I.; Maeda, H.; Komai, T.; Oda, T. Medium-chain fatty acid-sensing receptor, GPR84, is a proinflammatory receptor. J. Biol. Chem. 2013, 288, 10684-10691.

(9) Ichimura, A.; Hirasawa, A.; Hara, T.; Tsujimoto, G. Free fatty acid receptors act as nutrient sensors to regulate energy homeostasis. Prostaglandins Other Lipid Mediators 2009, 89, 82-88.

(10) Bouchard, C.; Pagé, J.; Bédard, A.; Tremblay, P.; Vallières, L. G protein-coupled receptor 84 , a microglia-associated protein expressed in neuroinflammatory conditions. Glia 2007, 55, 790-800.

(11) Oh, D. Y.; Talukdar, S.; Bae, E. J.; Imamura, T.; Morinaga, H.; Fan, W.; Li, P.; Lu, W. J.; Watkins, S. M.; Olefsky, J. M. GPR120 is an Omega3 fatty acid receptor mediating potent anti-inflammatory and insulinsensitizing effects. Cell 2010, 142, 687-698.

(12) Venkataraman, C.; Kuo, F. The G-protein coupled receptor, GPR84 regulates IL-4 production by $\mathrm{T}$ lymphocytes in response to CD3 crosslinking. Immunol. Lett. 2005, 101, 144-153.

(13) Huang, Q.; Feng, D.; Liu, K.; Wang, P.; Xiao, H.; Wang, Y.; Zhang, S.; Liu, Z. A medium-chain fatty acid receptor Gpr84 in zebrafish: expression pattern and roles in immune regulation. Dev. Comp. Immunol. 2014, 45, 252-258.

(14) Audoy-Rémus, J.; Bozoyan, L.; Dumas, A.; Filali, M.; Cynthia, L.; Lacroix, S.; Rivest, S.; Tremblay, M.-E.; Vallières, L. GPR84 deficiency reduces microgliosis, but accelerates dendritic degeneration and cognitive decline in a mouse model of Alzheimer's disease. Brain, Behav., Immun. 2015, 46, 112-120.

(15) Dietrich, P. A.; Yang, C.; Leung, H. H. L.; Lynch, J. R.; Gonzales, E.; Liu, B.; Haber, M.; Norris, M. D.; Wang, J.; Wang, J. Y. GPR84 sustains aberrant $\beta$-catenin signaling in leukemic stem cells for maintenance of MLL leukemogenesis. Blood 2014, 124, 3284-3294.

(16) Hoffmann, K.; Köse, M.; Schiedel, A.; Hartweg, J. L.; Schneider, M.; Foerch, P.; Gillard, M.; Müller, C. E.; von Kügelgen, I. Activation of human GPR84 by hydroxy-fatty acids and preparations of bacterial lipopolysaccharides. Eur. J. Pharmacol. 2018.

(17) Zhang, Q.; Yang, H.; Li, J.; Xie, X. Discovery and characterization of a novel small molecule agonist for medium chain free fatty acid receptor GPR84. J. Pharmacol. Exp. Ther. 2016, 357, 337-344. 
(18) Liu, Y.; Zhang, Q.; Chen, L.-H.; Yang, H.; Lu, W.; Xie, X.; Nan, F.J. Design and synthesis of 2-alkylpyrimidine-4,6-diol and 6-alkylpyridine-2,4-diol as potent GPR84 agonists. ACS Med. Chem. Lett. 2016, 7, 579-583.

(19) Hakak, Y.; Unett, D. J.; Gatlin, J.; Liaw, C. W. Human G ProteinCoupled Receptor and Modulators Thereof for the Treatment of Atherosclerosis and Atherosclerotic Disease and for the Treatment of Conditions Related to MCP-1 Expression. WO2007027661 A3, April 26, 2007.

(20) Krishnaswamy, M.; Purushothaman, K. K. Antifertility properties of Embelia ribes: (embelin). Indian J. Exp. Biol. 1980, 18, 1359-1360.

(21) Chitra, M.; Sukumar, E.; Suja, V.; Devi, C. S. S. Antitumor, antiinflammatory and analgesic property of embelin, a plant product. Chemotherapy 1994, 40, 109-113.

(22) Chitra, M.; Devi, C. S. S.; Sukumar, E. Antibacterial activity of embelin. Fitoterapia 2003, 74, 401-403.

(23) Kundap, U. P.; Bhuvanendran, S.; Kumari, Y.; Othman, I.; Shaikh, M. F. Plant derived phytocompound, embelin in CNS Disorders: A systematic review. Front. Pharmacol. 2017, 8, 76.

(24) Takeda, S.; Yamamoto, A.; Okada, T.; Matsumura, E.; Nose, E.; Kogure, K.; Kojima, S.; Haga, T. Identification of surrogate ligands for orphan G protein-coupled receptors. Life Sci. 2003, 74, 367-377.

(25) (a) Fares, F. The anti-carcinogenic effect of indole-3-carbinol and 3,3'-diindolylmethane and their mechanism of action. Med. Chem. 2014, S1, 1-8. (b) Kiselev, V. I.; Drukh, V. M.; Muyzhnek, E. L.; Kuznetsov, I. N.; Pchelintseva, O. I.; Paltsev, M. A. Preclinical antitumor activity of the diindolylmethane formulation in xenograft mouse model of prostate cancer. Exp. Oncol. 2014, 36, 90-93. (c) Firestone, G. L.; Bjeldanes, L. F. Indole-3-carbinol and 3-3'-diindolylmethane antiproliferative signaling pathways control cell-cycle gene transcription in human breast cancer cells by regulating promoter-Sp1 transcription factor interactions. J. Nutr. 2003, 133, 2448S-2455S.

(26) Pillaiyar, T.; Köse, M.; Sylvester, K.; Weighardt, H.; Thimm, D.; Borges, G.; Förster, I.; von Kügelgen, I.; Müller, C. E. Diindolylmethane derivatives: Potent agonists of the immunostimulatory orphan G protein-coupled receptor GPR84. J. Med. Chem. 2017, 60, 3636-3655.

(27) Nikaido, Y.; Koyama, Y.; Yoshikawa, Y.; Furuya, T.; Takeda, S. Mutation analysis and molecular modeling for the investigation of ligand-binding modes of GPR84. J. Biochem. 2015, 157, 311-320.

(28) Southern, C.; Cook, J. M.; Neetoo-Isseljee, Z.; Taylor, D. L.; Kettleborough, C. A.; Merritt, A.; Bassoni, D. L.; Raab, W. J.; Quinn, E.; Wehrman, T. S.; Davenport, A. P.; Brown, A. J.; Green, A.; Wigglesworth, M. J.; Rees, S. Screening $\beta$-arrestin recruitment for the identification of natural ligands for orphan G-protein-coupled receptors. J. Biomol. Screening 2013, 18, 599-609.

(29) https://www.discoverx.com/DiscoveRx/media/ContentFiles/ DataSheets/95-0158C2.pdf.

(30) Seward, E.; Diederich, F. Redox-dependent complexation ability of flavin-hosts in aqueous solution. Tetrahedron Lett. 1987, 28, 51115114.

(31) Dickens, M. P.; Roxburgh, P.; Hock, A.; Mezna, M.; Kellam, B.; Vousden, K. H.; Fischer, P. M. 5-Deazaflavin derivatives as inhibitors of p53 ubiquitination by HDM2. Bioorg. Med. Chem. 2013, 21, 6868-6877.

(32) El-Emam, A. A.; Massoud, M. A. M.; El-Bendary, E. R.; El-Sayed, M. A. Synthesis of certain 6-(arylthio)uracils and related derivatives as potential antiviral agents. Bull. Korean Chem. Soc. 2004, 25, 991-996.

(33) Winpenny, D.; Clark, M.; Cawkill, D. Biased ligand quantification in drug discovery: from theory to high throughput screening to identify new biased $\mu$ opioid receptor agonists. Br. J. Pharmacol. 2016, 173, 1393-1403.

(34) Manglik, A.; Lin, H.; Aryal, D. K.; McCorvy, J. D.; Dengler, D.; Corder, G.; Levit, A.; Kling, R. C.; Bernat, V.; Hübner, H.; Huang, X.-P.; Sassano, M. F.; Giguère, P. M.; Löber, S.; Duan, D.; Scherrer, G.; Kobilka, B. K.; Gmeiner, P.; Roth, B. L.; Shoichet, B. K. Structure-based discovery of opioid analgesics with reduced side effects. Nature 2016, 537, 185-190.

(35) Thimm, D.; Knospe, M.; Abdelrahman, A.; Moutinho, M.; Alsdorf, B. B. A.; von Kügelgen, I.; Schiedel, A. C.; Müller, C. E.
Characterization of new $\mathrm{G}$ protein-coupled adenine receptors in mouse and hamster. Purinergic Signalling 2013, 9, 415-426.

(36) Molecular Operating Environment (MOE), 2014.09; Chemical Computing Group Inc.: Montreal, QC, Canada, 2016.

(37) Labute, P.; Williams, C.; Feher, M.; Sourial, E.; Schmidt, J. M. Flexible alignment of small molecules. J. Med. Chem. 2001, 44, 14831490.

(38) Halgren, T. A. Merck molecular force field. I. Basis, form, scope, parameterization, and performance of MMFF94. J. Comput. Chem. 1996, $17,490-519$. 